July $1999 \quad$ • NREL/SR-520-26295

\title{
China PV Business and Applications Evaluation
}

\section{September-October 1998}

Chris Sherring

Sherring Energy Associates

Princeton, New Jersey

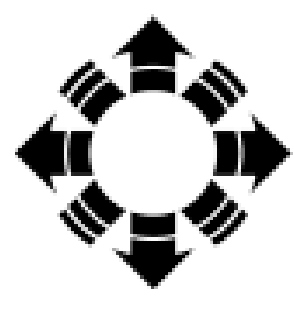

National Renewable Energy Laboratory

1617 Cole Boulevard

Golden, Colorado 80401-3393

NREL is a U.S. Department of Energy Laboratory

Operated by Midwest Research Institute $\bullet$ Battelle $\bullet$ Bechtel

Contract No. DE-AC36-98-G010337 


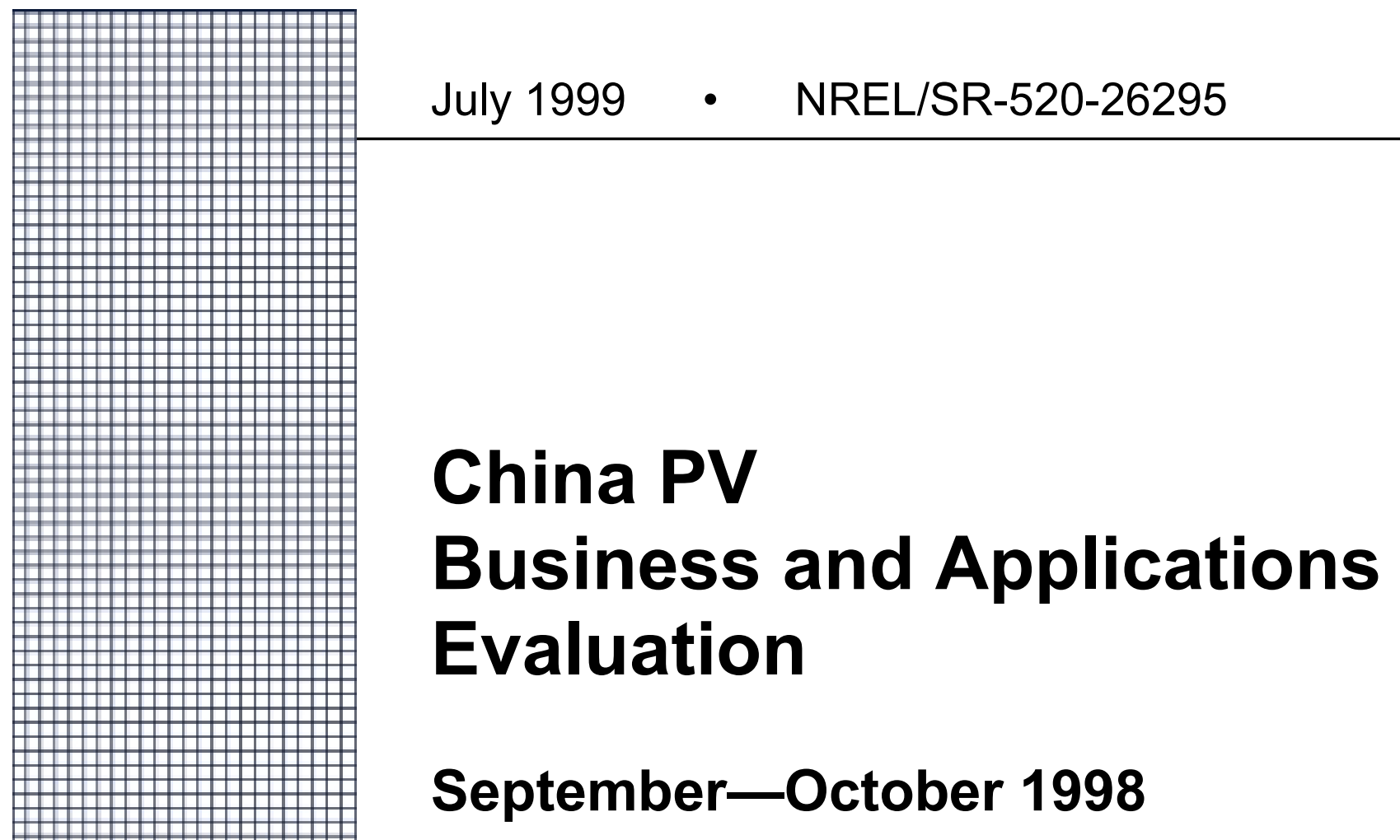

Chris Sherring

Sherring Energy Associates

Princeton, New Jersey

NREL Technical Monitor: William Wallace

Prepared under Subcontract No. AAA-8-18688-01

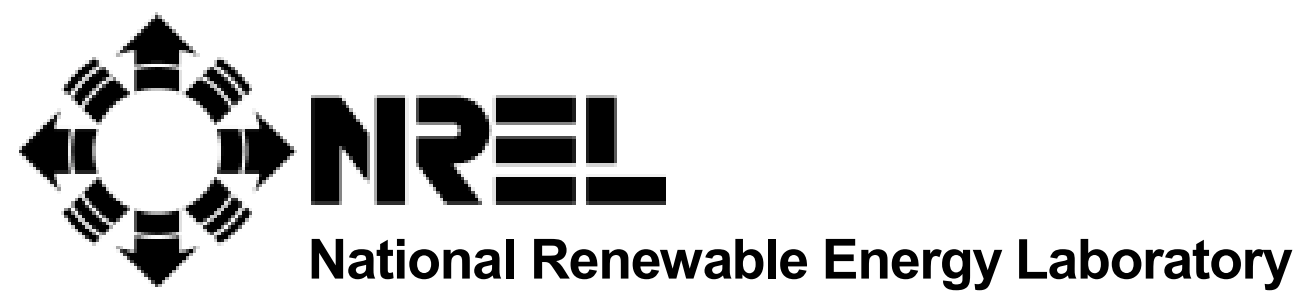

1617 Cole Boulevard

Golden, Colorado 80401-3393

NREL is a U.S. Department of Energy Laboratory

Operated by Midwest Research Institute $\bullet$ Battelle $\bullet$ Bechtel

Contract No. DE-AC36-98-G010337 


\section{NOTICE}

This report was prepared as an account of work sponsored by an agency of the United States government. Neither the United States government nor any agency thereof, nor any of their employees, makes any warranty, express or implied, or assumes any legal liability or responsibility for the accuracy, completeness, or usefulness of any information, apparatus, product, or process disclosed, or represents that its use would not infringe privately owned rights. Reference herein to any specific commercial product, process, or service by trade name, trademark, manufacturer, or otherwise does not necessarily constitute or imply its endorsement, recommendation, or favoring by the United States government or any agency thereof. The views and opinions of authors expressed herein do not necessarily state or reflect those of the United States government or any agency thereof.

Available to DOE and DOE contractors from:

Office of Scientific and Technical Information (OSTI)

P.O. Box 62

Oak Ridge, TN 37831

Prices available by calling 423-576-8401

Available to the public from:

National Technical Information Service (NTIS)

U.S. Department of Commerce

5285 Port Royal Road

Springfield, VA 22161

$703-605-6000$ or $800-553-6847$

or

DOE Information Bridge

http://www.doe.gov/bridge/home.html

Printed on paper containing at least $50 \%$ wastepaper, including $20 \%$ postconsumer waste 


\section{Preface}

This report, which is the result of our visit to China during September-October 1998, evaluates the current status of photovoltaics (PV) business and applications in China. In the first section, an overview summarizes the findings; the remainder of this section describes the current status of the key aspects of the PV businesses, markets, and distribution channels. The next section provides data obtained from the businesses in the form of a completed questionnaire and company/organization profiles information organized in a table format. The following section includes a detailed itinerary of the trip. The contact information for all of the experts interviewed during the trip (Business Card Listing) is provided in the next section. Detailed company/organization profiles and summaries of visits made to China are provided in the subsequent section. These summaries were developed from the minutes of the various meetings that took place during the visits. The final section of the report offers a "photo album" consisting of snapshots of the Chinese businesses and/or their operations.

This composite document provides only some of the information gathered during this visit; more detailed, customized information, pertinent to specific sectors of the U.S. PV industry, is best conveyed directly to individual PV companies. 


\section{Table of Contents}

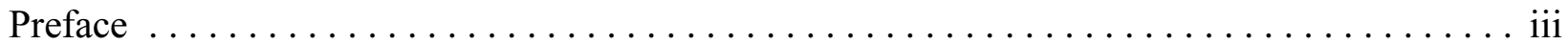

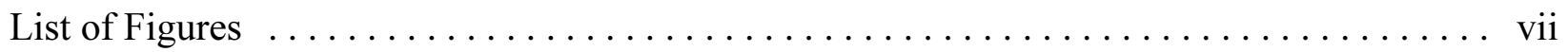

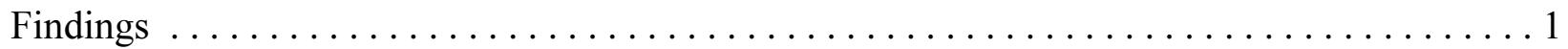

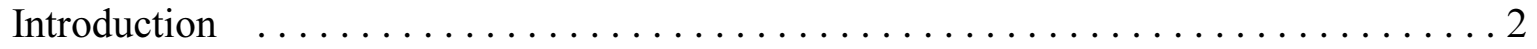

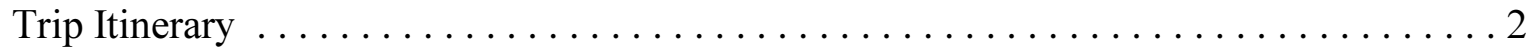

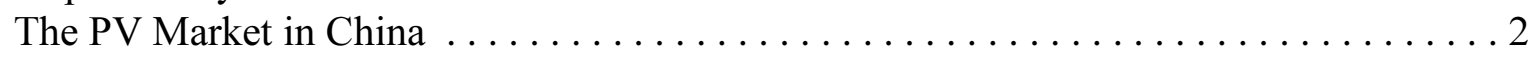

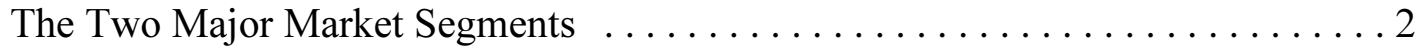

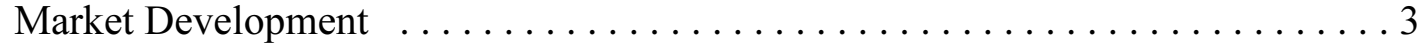

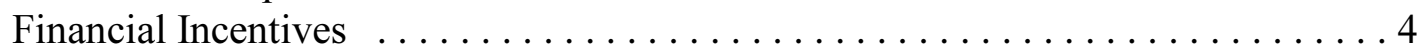

PV Product Distribution in China $\ldots \ldots \ldots \ldots \ldots \ldots \ldots \ldots \ldots \ldots \ldots \ldots$

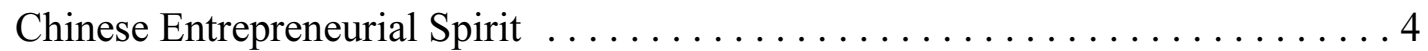

The PV Product Distribution Network $\ldots \ldots \ldots \ldots \ldots \ldots \ldots \ldots \ldots \ldots$

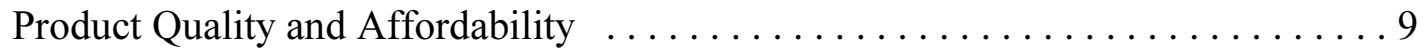

PV Manufacturing in China . . . . . . . . . . . . . . . . . . . . . . 11

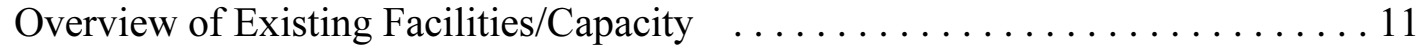

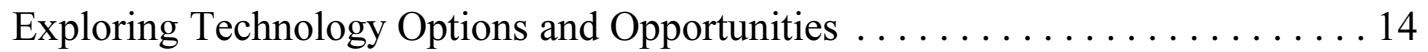

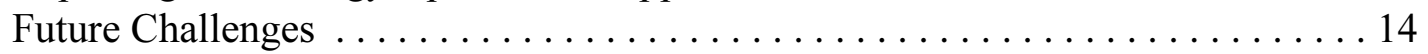

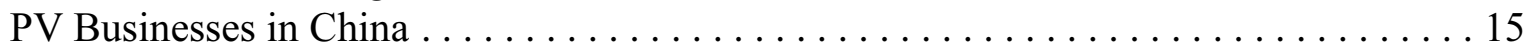

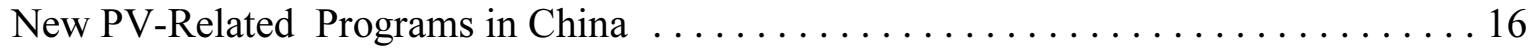

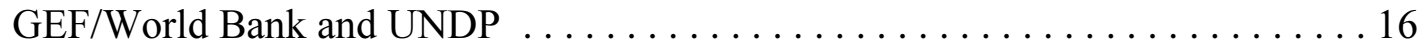

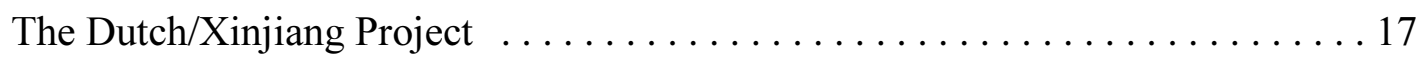

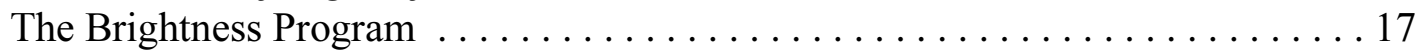

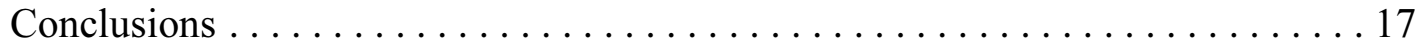

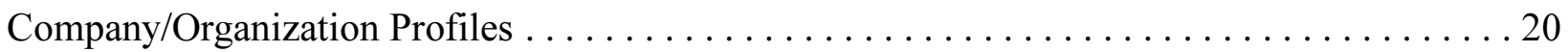

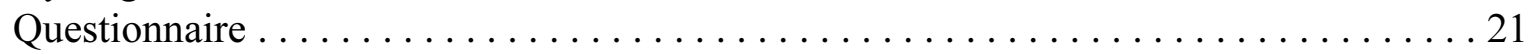

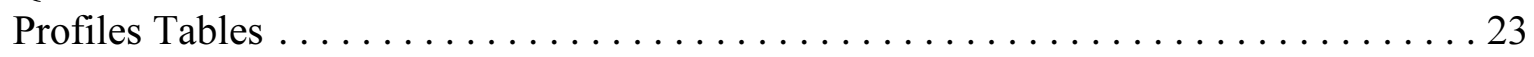

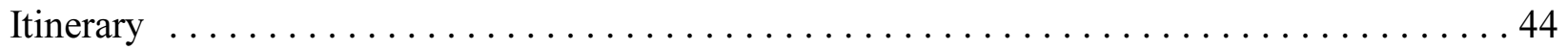

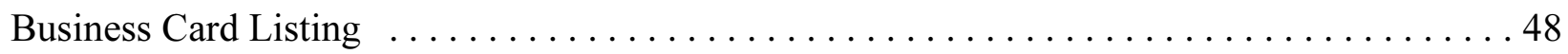

Visit Report_-Detailed Company/Organization Profiles $\ldots \ldots \ldots \ldots \ldots \ldots \ldots \ldots$

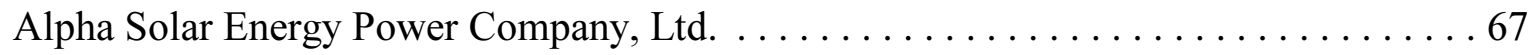

Beijing General Research Institute for Non-Ferrous Metals . . . . . . . . . . . . 67

Beijing New Building Materials Company, Ltd. . . . . . . . . . . . . . . 68

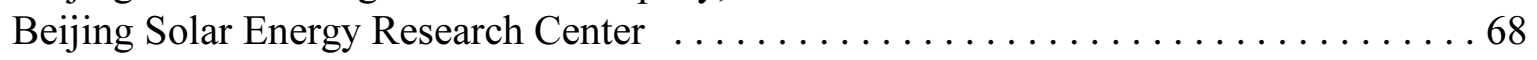

Beinei Group Corporation-Diesel Engine Factory $\ldots \ldots \ldots \ldots \ldots \ldots \ldots \ldots \ldots$

Center for Renewable Energy Development $\ldots \ldots \ldots \ldots \ldots \ldots \ldots \ldots$

China Photovoltaic Technology Development Center . . . . . . . . . . . . . 71

Dawa Solar Energy Company, Ltd. of Xining, Qinghai . . . . . . . . . . . . 73

Gansu GNERI Solar Electric Power Company, Ltd. . . . . . . . . . . . . . . . . . . 73

Gansu Provincial Electronic Industry Corporation $\ldots \ldots \ldots \ldots \ldots \ldots \ldots \ldots$

Gansu PV Company Ltd. . . . . . . . . . . . . . . . . . . . 76 


\section{Table of Contents (continued)}

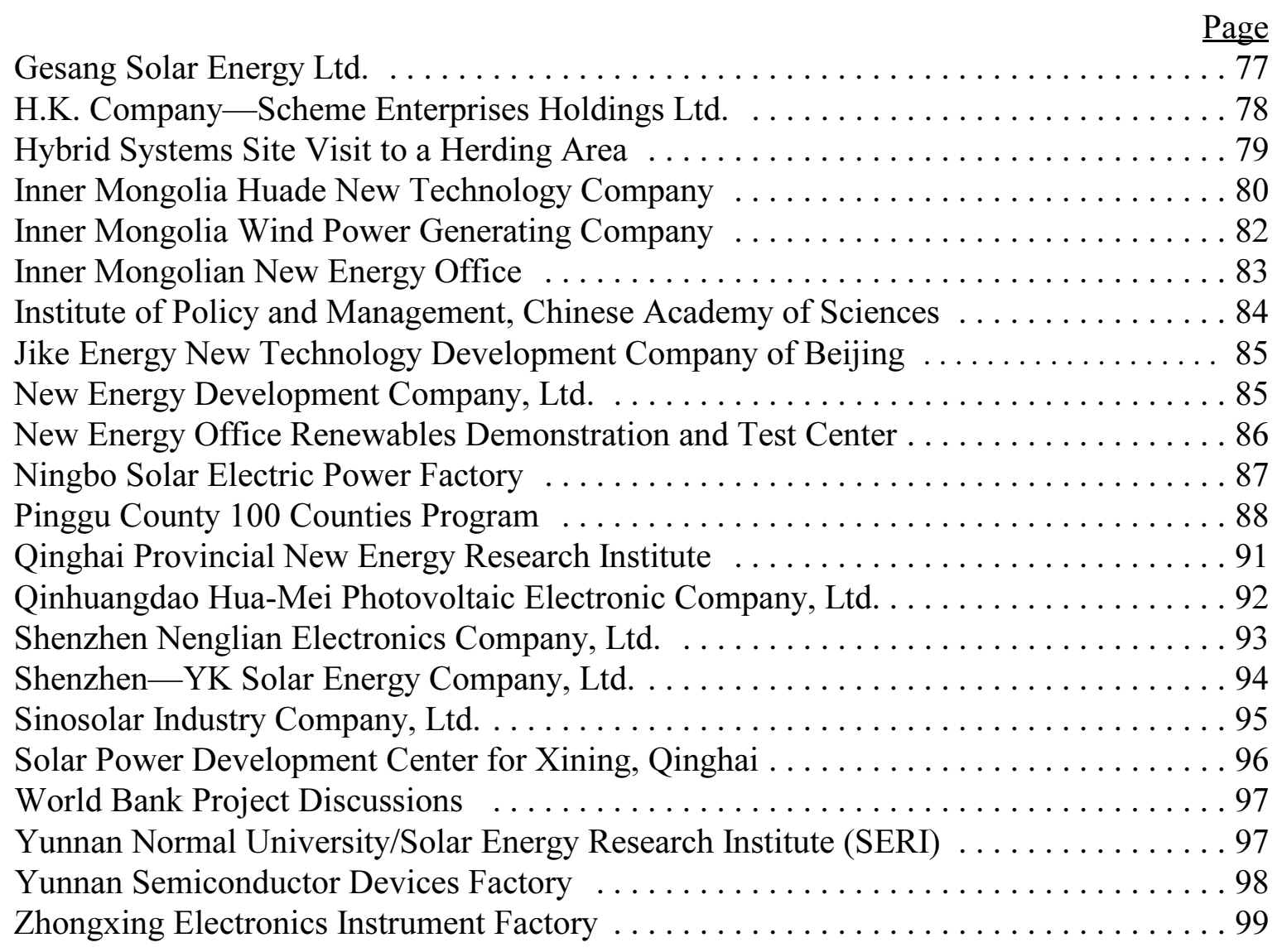

Photo Album 


\section{List of Figures}

Page

Figure 1. Typical solar home system $\ldots \ldots \ldots \ldots \ldots \ldots \ldots \ldots \ldots \ldots \ldots \ldots \ldots$

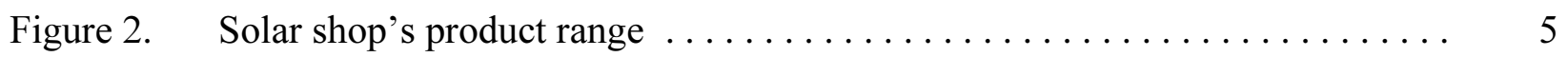

Figure 3. Typical solar shop $\ldots \ldots \ldots \ldots \ldots \ldots \ldots \ldots \ldots \ldots \ldots \ldots \ldots \ldots \ldots \ldots \ldots \ldots$

Figure 4. Remote hybrid-powered home-Inner Mongolia $\ldots \ldots \ldots \ldots \ldots \ldots \ldots$

Figure 5. Hybrid system wiring and electronics $\ldots \ldots \ldots \ldots \ldots \ldots \ldots \ldots \ldots \ldots$

Figure 6. Remote hybrid site - Inner Mongolia $\ldots \ldots \ldots \ldots \ldots \ldots \ldots \ldots \ldots$

Figure 7. No wire and no neighbors-Inner Mongolia $\ldots \ldots \ldots \ldots \ldots \ldots \ldots \ldots$

Figure 8. Collection tank under construction for biomass system $\ldots \ldots \ldots \ldots \ldots \ldots$

Figure 9. Inner Mongolia site visit team $\quad \ldots \ldots \ldots \ldots \ldots \ldots \ldots \ldots \ldots \ldots \ldots \ldots$

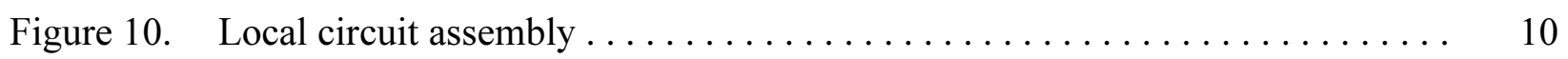

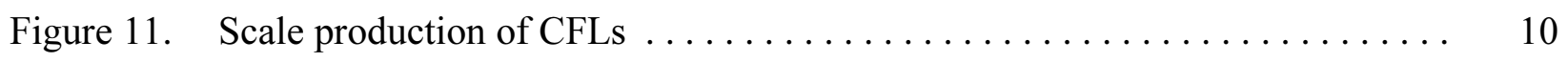

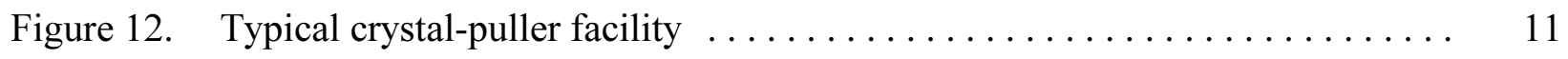

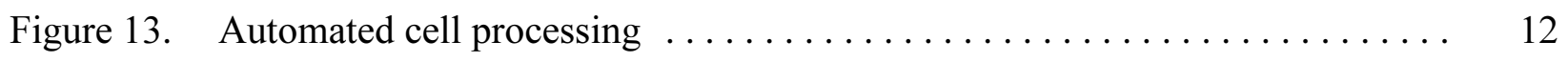

Figure 14. Amorphous silicon deposition chambers $\ldots \ldots \ldots \ldots \ldots \ldots \ldots \ldots \ldots . \ldots \ldots$

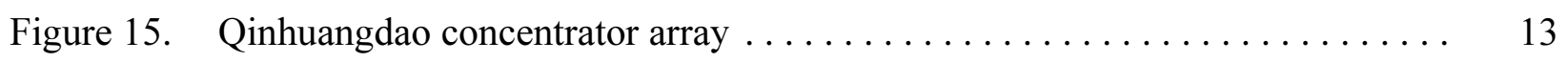

Figure 16. Shenzhen roof-mounted array $\ldots \ldots \ldots \ldots \ldots \ldots \ldots \ldots \ldots \ldots \ldots \ldots \ldots \ldots \ldots$ 
Findings 


\section{Findings}

\section{Introduction}

During the course of our 40-day visit to China, we met with more than 100 specialists in the Chinese renewables industry including all of the indigenous photovoltaics (PV) manufacturers, most of the distributors/systems integrators, and the key institutions involved in developing PV technologies and business. We also received considerable assistance from the Center for Renewable Energy Development, as well as 10 or more capable interpreters. With the help of all these sources, we were able to confirm that there are many encouraging signs - as well as many critical challenges - for both the international and indigenous PV industries in the energy markets in China.

Although more than 70 million people in China are without access to grid electricity, many of the unelectrified regions benefit from considerable renewable resources, including good solar insolation. Current annual PV sales are still modest, however, and are estimated to be between 2.0 and 2.5 megawatts (MW). The total market, which was about $2 \mathrm{MW}$ per annum in 1998, is expected to grow at a yearly rate of between $20 \%$ and $30 \%$.

\section{Trip Itinerary}

Our China trip began in Beijing in early September 1998; subsequent visits were then made to Qinghai and Gansu, two of the northwestern provinces where many of the PV system distributors/integrators are based. We then returned to Beijing for visits to local institutes and attended the jointly sponsored Ministry of Agriculture and U.S. Department of Energy (DOE) renewables workshop. The next visit was to Zhejiang Province, which borders the east coast, for meetings at the Solar PV center and one of the PV module plants. Moving south, we then visited Guangdong province and its Shenzhen Special Economic Zone (SEZ) (adjacent to Hong Kong), followed by a visit to Foshan further to the west. The southwestern province of Yunnan and its capital Kunming (where another major PV module manufacturer is located) was next on the list. After passing through Beijing briefly, the next stop was in Qinhuangdao, the location of two more PV manufacturers (only a few hours train ride to the northeast of Beijing). After pausing for the Chinese national holiday, we visited Beijing, Hong Kong, and Inner Mongolia. All subsequent meetings and visits occurred in and around the Beijing area before our return to the United States in mid-October.

\section{The PV Market in China}

\section{The Two Major Market Segments}

The PV market in China is divided into the following two segments: industrial systems for powering communications in remote communities, such as the microwave repeater stations, fiber-optic links, and a small number of village power systems that range from a few kilowatts $(\mathrm{kW})$ to $50 \mathrm{~kW}$; and solar home systems (SHSs), which can be as small as $4 \mathrm{~W}$ or as large as $500 \mathrm{~W}$. The latter provide power to satellite receivers and to remote households. Larger systems can consist of PV/wind hybrid systems with battery storage.

The industrial market segment, which is largely dependent on a small number of government contracts, is serviced by a very small number of system integrators, some of whom also manage their own module manufacture and assembly operations. The SHS market, by contrast, is served by many and varied types of suppliers, including nearly all the crystal silicon module manufacturers and the vast majority of the mediumand small-system integrators/distributors. Nearly all sales in both segments are made without any credit; however, in the SHS segment, small amounts of credit are provided by some module suppliers to their customers, who are the system integrators/distributors. 
Typically, indigenous PV modules in China sell for between $\$ 5$ and $\$ 5.50$ per watt, whereas small systems sell at approximately $\$ 10$ per watt. Imported modules command a slight selling price premium.

\section{Market Development}

The vast majority of PV sales are made to remote rural provinces and autonomous regions such as Tibet, Xinjiang, Qinghai, Gansu, and Inner Mongolia; however, the PV production plants are mostly located thousands of miles away from these key markets. Currently, $90 \%$ of the modules supplied to the market in China are of indigenous manufacture. In addition, China exports single-crystal ingots and wafers $(\sim 1 \mathrm{MW})$ and most of the local thin-film production $(\sim 500 \mathrm{~kW})$.

The PV market in China is at the early stages of development and the vast majority of the end customers are unable to evaluate the performance of the systems that are on offer. The vast distances between average rural customers in northwest China hinders the development of customer knowledge. For the SHS market, selling price is the key driver; as a result, the trend in recent years has been for the systems offered to become smaller to reach lower desired selling prices. The smallest SHS currently on offer has a capacity of 4 watts and the vast majority of the systems sold are below 20 watts (see Figure 1). Given the unsophisticated nature of the majority of SHS customers, some of the retailers (solar shops) tend to price systems according to the physical size of the module rather than the measured peak wattage of the module. Bigger is assumed, by the end customer, to be more valuable; however, given the range of cell diameters and efficiencies (and, hence, module area efficiencies), the actual size of a module may bear little resemblance to the module's effectiveness in a system.

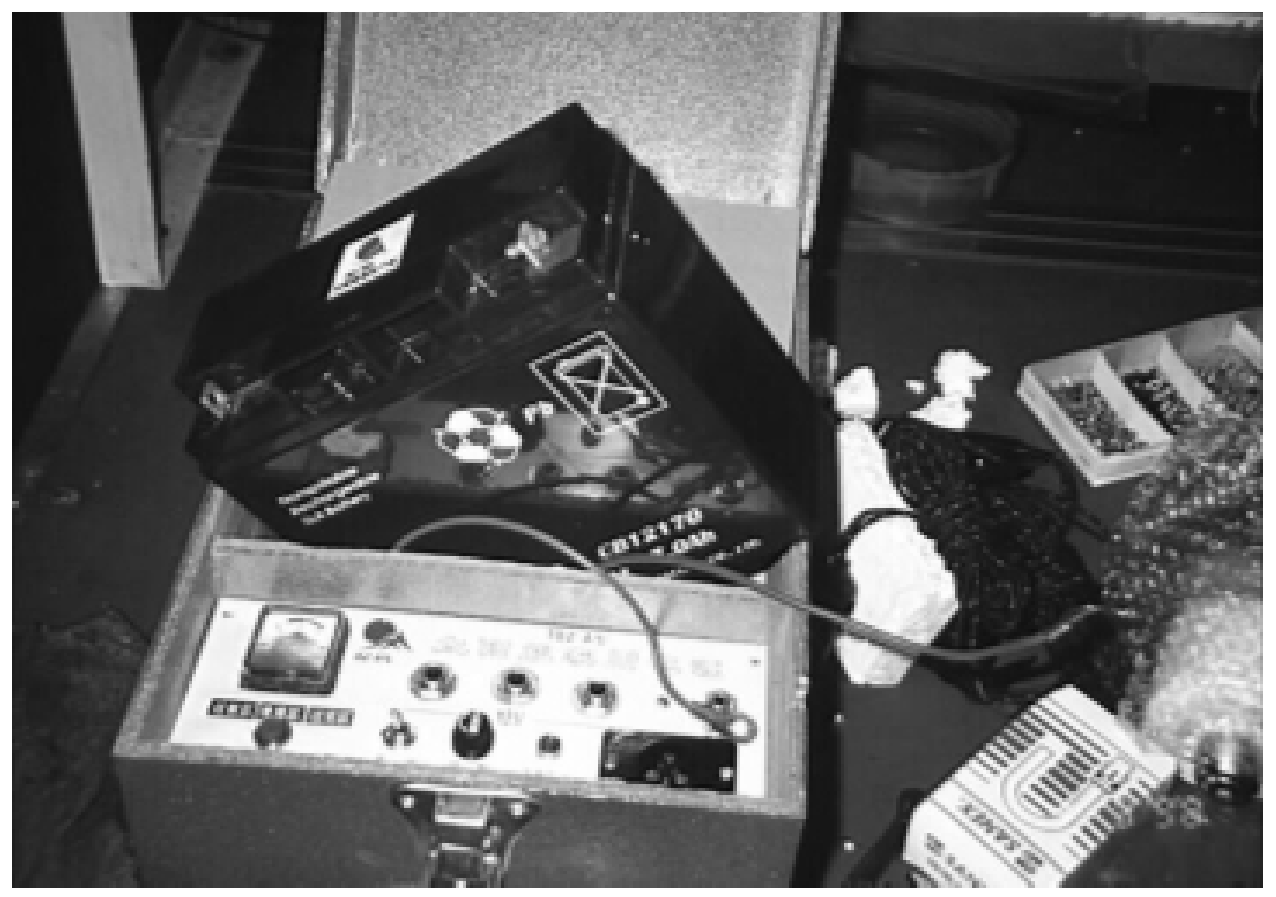

Figure 1. Typical solar home system 


\section{Financial Incentives}

Unlike other regions of the world, there are as yet no country-wide financial incentives in China to promote the use of PV and other renewables. The individual provinces have various subsidy programs targeting specific renewables and poverty alleviation funds are also used to reduce the cost of renewable power for remote, unelectrified homes. Although most forms of subsidy (designed initially to encourage technology adoption) can, after time, "distort" the market, the situation in China, particularly as it relates to small SHSs, appears to be coming close to a free market. The establishment and continuity of numerous solar shops and the healthy level of cash sales reflect a very significant commercial opportunity, considering the tens of millions of Chinese who do not have and will never have grid electricity. There is the risk, however, that failure to ensure that the cash customers are sold reliable products and provided with essential services, will damage the embryonic commercial market.

If large-scale bilateral programs such as the Dutch/Xinjiang project introduce unrealistic subsidies on PV systems (rather than offset the nonrecurring infrastructure investment), there is a real chance that the natural market mechanisms operating throughout northwestern China - the major market - will be destroyed. Similarly, if multilateral programs in China focus on accelerating market growth without fixing current product reliability and service infrastructure problems, the enormous PV market potential ( $>15 \mathrm{MW}$ per annum) might be lost forever or significantly delayed.

\section{PV Product Distribution in China}

\section{Chinese Entrepreneurial Spirit}

The entrepreneurial spirit in China that has been clearly evident amongst private-sector distributors is increasingly being given every encouragement in the state sector, even within the many research institutions that are having to sell product to survive. This seemingly boundless entrepreneurial spirit impacts PV distribution most noticeably in the efforts of many small distributors/integrators, which have emerged to offer PV packaged products to rural customers at affordable prices. Although these distributors might typically employ 20-30 people and develop a network of sales outlets, they also try to "manufacture" much of the balance of systems (BOS) for the SHS to improve short-term profit margins. Typically, the depth of technical understanding and the appreciation of the type of manufacturing regime essential for the production of reliable, cost-effective electronics for remote rural applications, is limited or nonexistent.

\section{The PV Product Distribution Network}

Although the many distributors/integrators, some of whose businesses are profiled later in this section, obviously have varying degrees of technical and manufacturing skills, they have all developed multi-path channels to the rural markets. Many of the distributors have their own products or sell them through one of the shops on the "solar street" in Xining, Qinghai (see Figures 2 and 3). These shops, of which there are at least nine (not all in the one street), essentially all sell the same products, albeit from different manufacturers or with different logos, at more or less the same price. There is very little product differentiation as yet in these early stages of market development. Some outlets will focus on a specific ethnic group, as in the case of the Tibetan distributor that offers a complete range of Tibetan products in its Xining shop ranging from solar PV to dried yak meat to Tibetan video disks; however, there is little apparently that differentiates the other product offerings from each other. Because all these shops are currently viable despite the similarity of product, the inherent market potential is clearly evident.

In addition to shops, each of the distributors has developed various agents and regional salespeople who either sell on commission, buy and sell the product, or are fully funded by the distributor to sell the product 


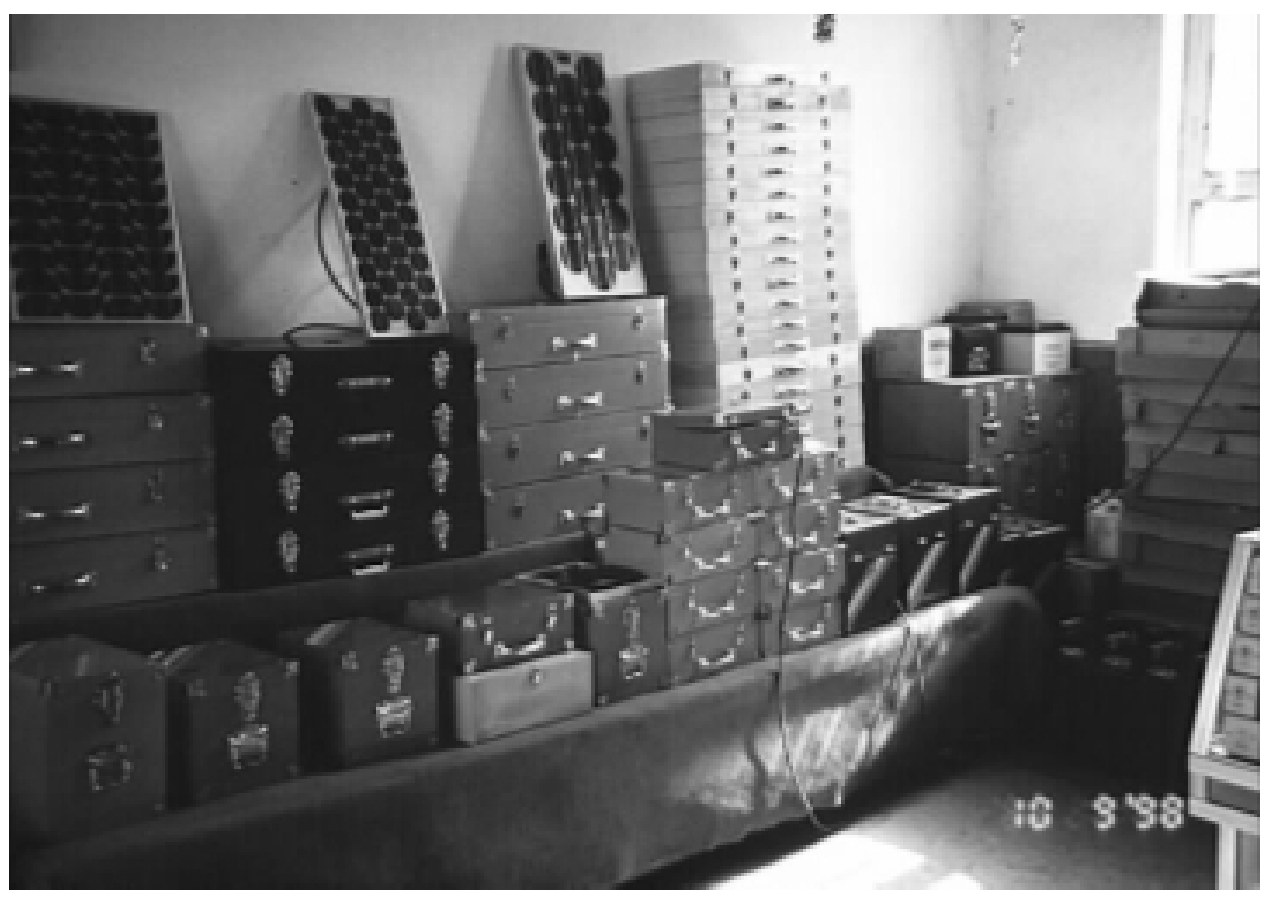

Figure 2. Solar shop's product range

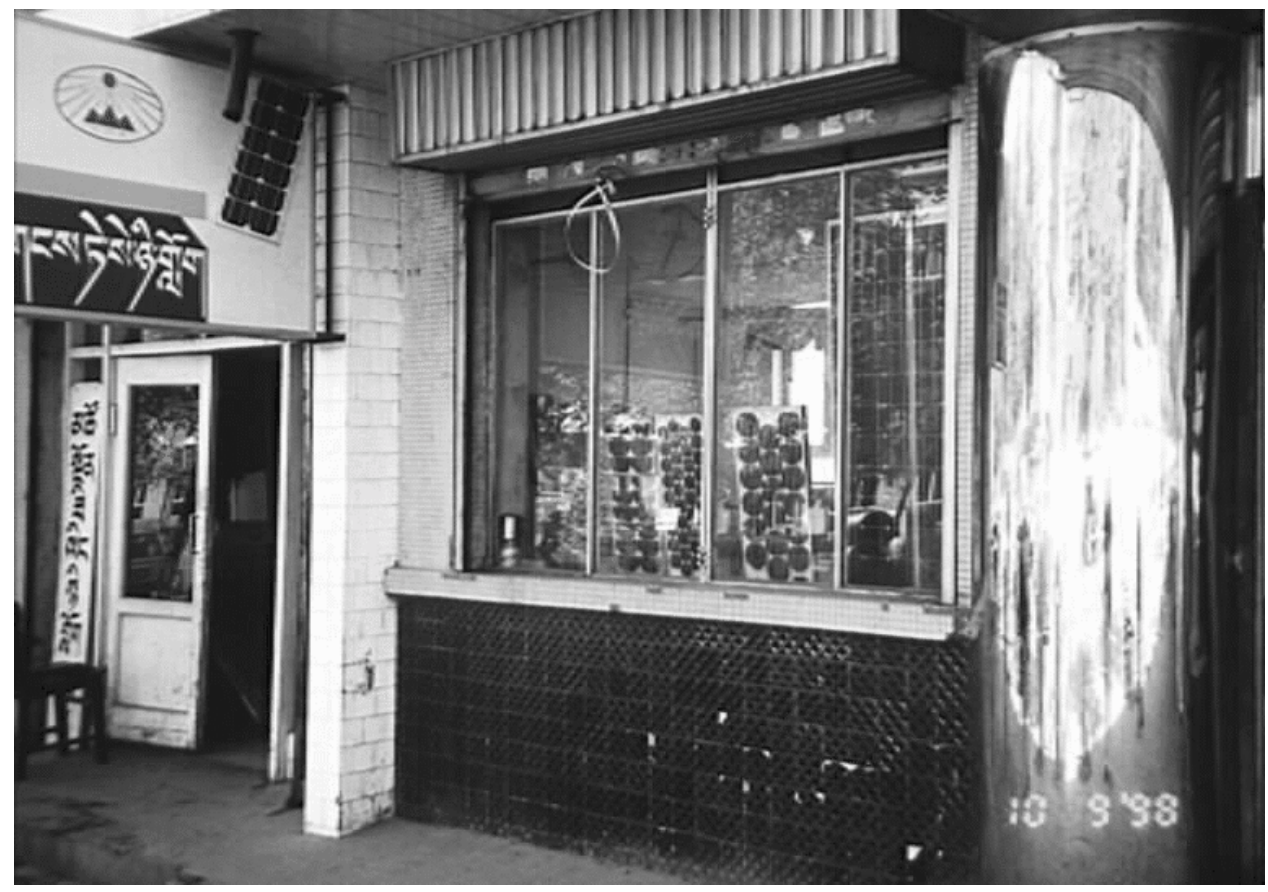

Figure 3. Typical solar shop 
in a particular region. As for product maintenance and guarantees, most distributors say that their agents and sales outlets carry out repairs of product under warranty. Some distributors go as far as leaving $10 \%$ of the purchase price (above and beyond commission) with the agent to cover possible repairs within the guarantee period. In the event that the product does not require repair, the remainder of the funds are passed to the distributor. Some distributors provide product training for their various agents; however, others talk of requiring the remote rural customer to mail the product back. When asked how many customers in any given year have mailed the product back, the remarkable answer is often zero. This cannot be simply interpreted in terms of the reliability of the product supplied; rather, what must also be taken into account is the logistical challenge facing a rural herdsman (who is possibly $50 \mathrm{~km}$ from the nearest small town), who has to mail an SHS to a distributor/integrator several provinces distant.

Some provincial energy offices have developed a network of county-level rural energy service centers with trained staff who also are beginning to sell commercial renewables product; however, many of the typical maintenance challenges currently experienced with the rural systems, namely repair to the circuit boards, require that the product be returned to the manufacturer. The rural herdsman, who typically has modest PV systems knowledge, may be as far as $100 \mathrm{~km}$ from the rural service center; without either electricity or phone, he needs to determine that the product has to be conveyed to the original manufacturer. (See Figures 4 through 7. Figures 8 and 9 depict construction associated with the ongoing 100 Counties Program and the comprehensive team that visited the hybrid units in Inner Mongolia.)

Larger state-owned distributors/integrators have launched market awareness/conditioning programs for PV and other renewables that include radio and newspaper advertising, as well as the distribution of product samples. The industrial market segment, which includes telecommunications power units, microwave repeater stations, and some village and island power units, is primarily served by a few established, full-service system integrators such as Beijing Jike Energy New Technology Development Company, Ltd., as well as some provincial research institutes. Few of the PV manufacturers, however, have the experience and resources to address this market segment. More typically, they simply supply the PV modules under contract

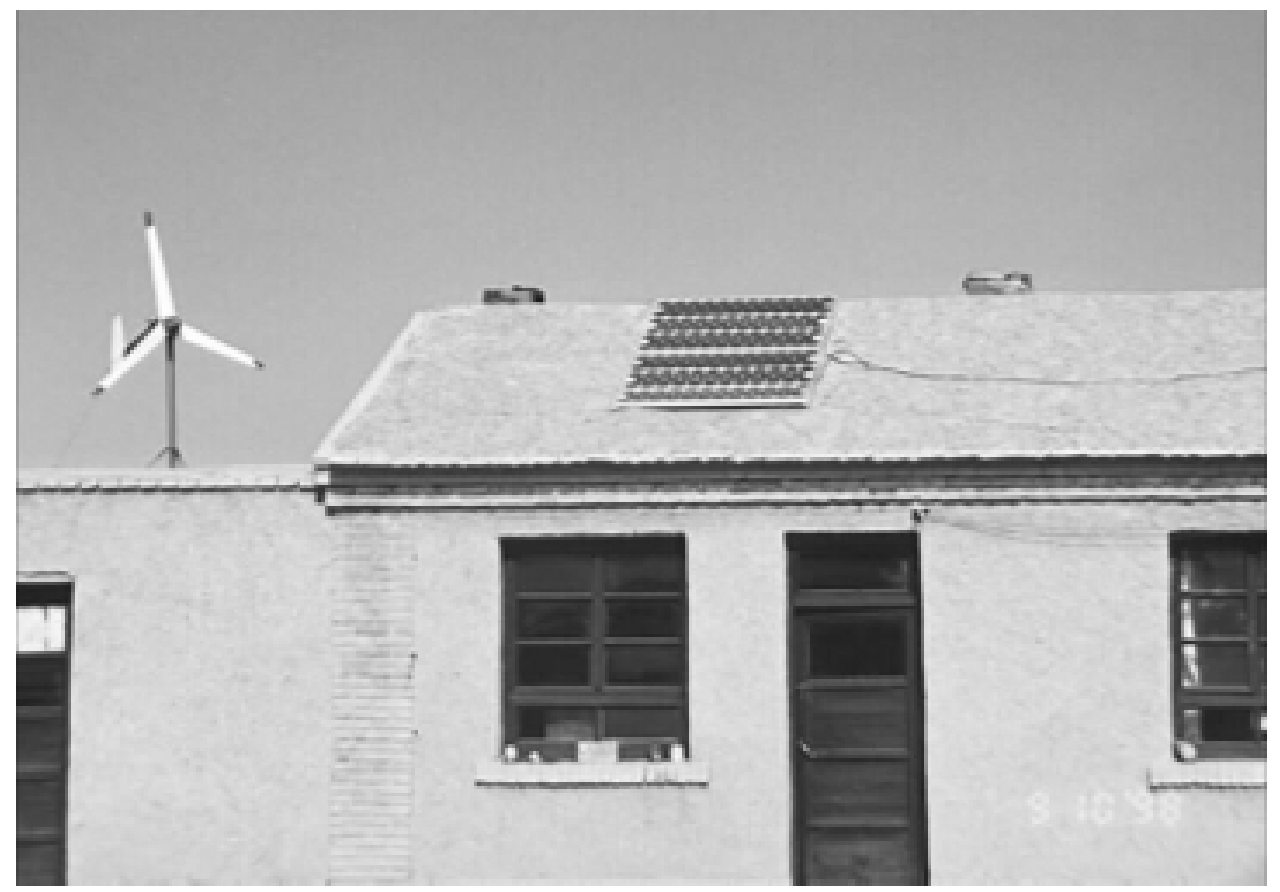

Figure 4. Remote hybrid-powered home-Inner Mongolia 


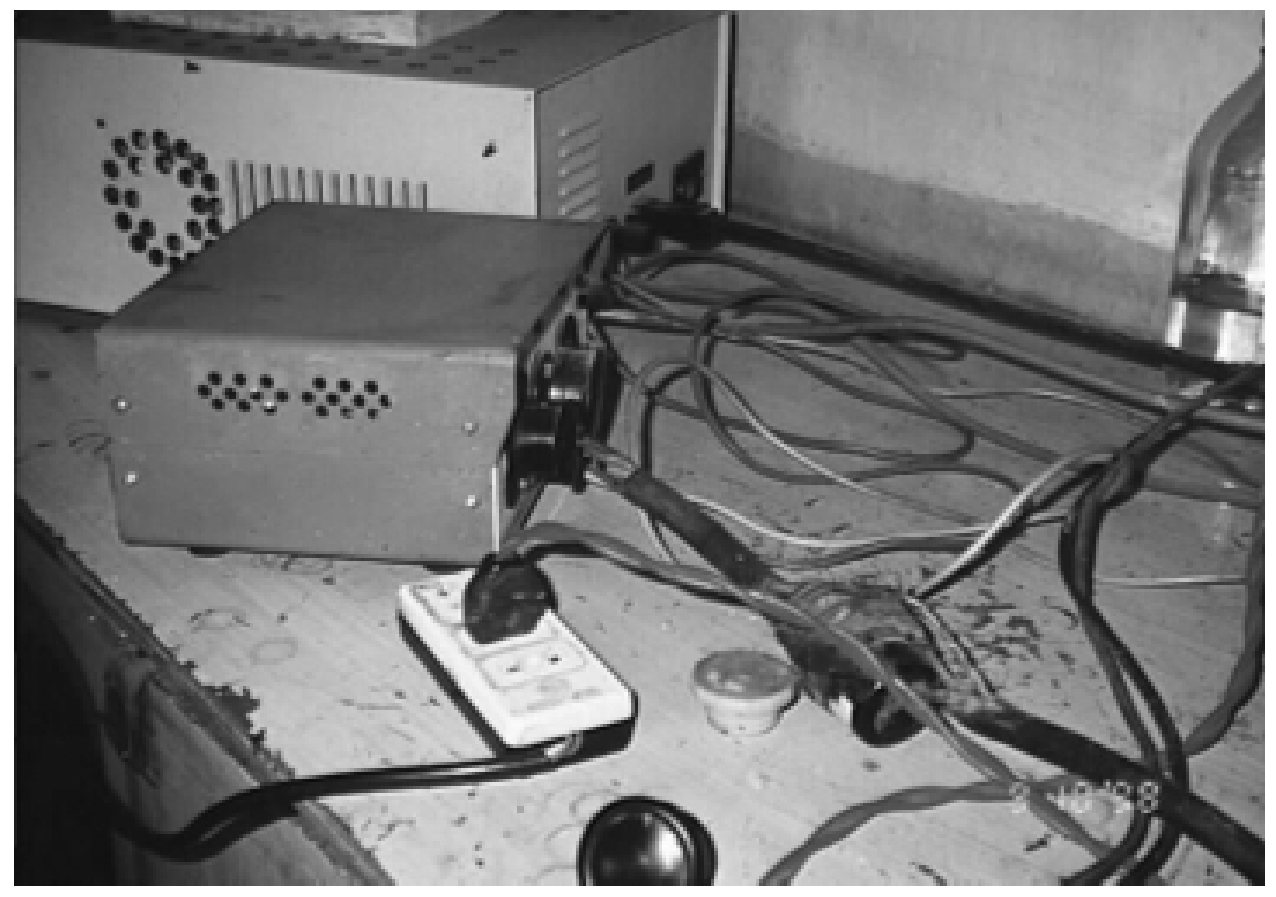

Figure 5. Hybrid system wiring and electronics

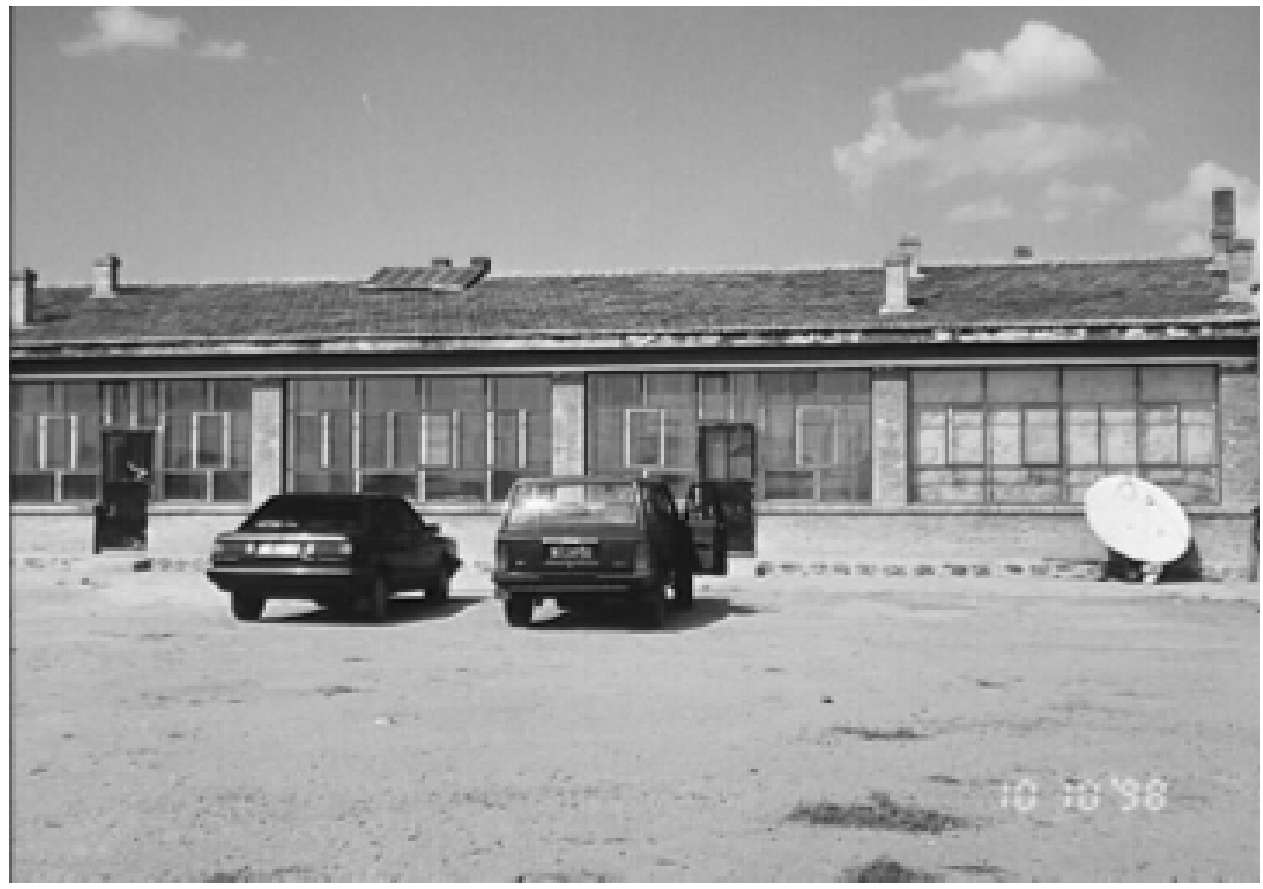

Figure 6. Remote hybrid site_-Inner Mongolia 


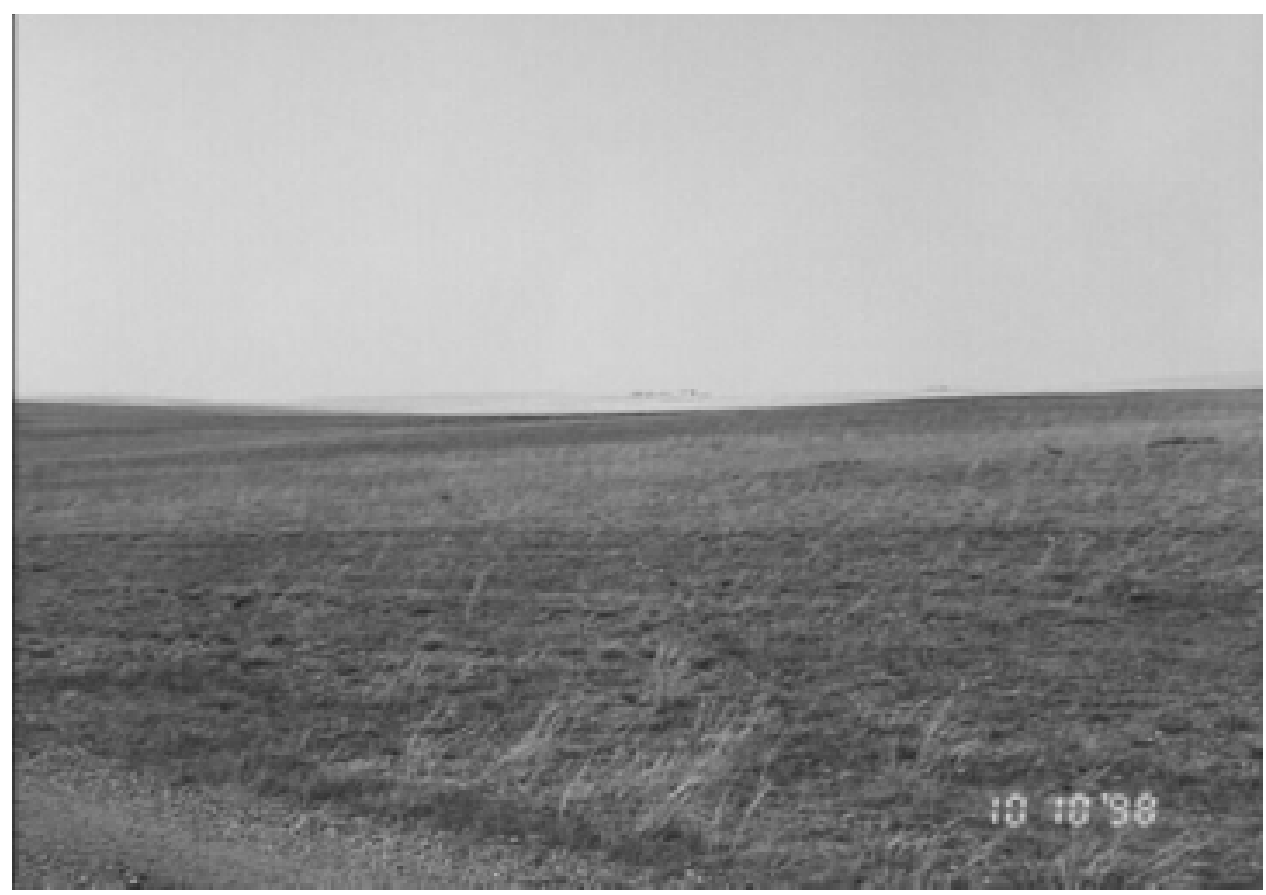

Figure 7. No wires and no neighbors-Inner Mongolia

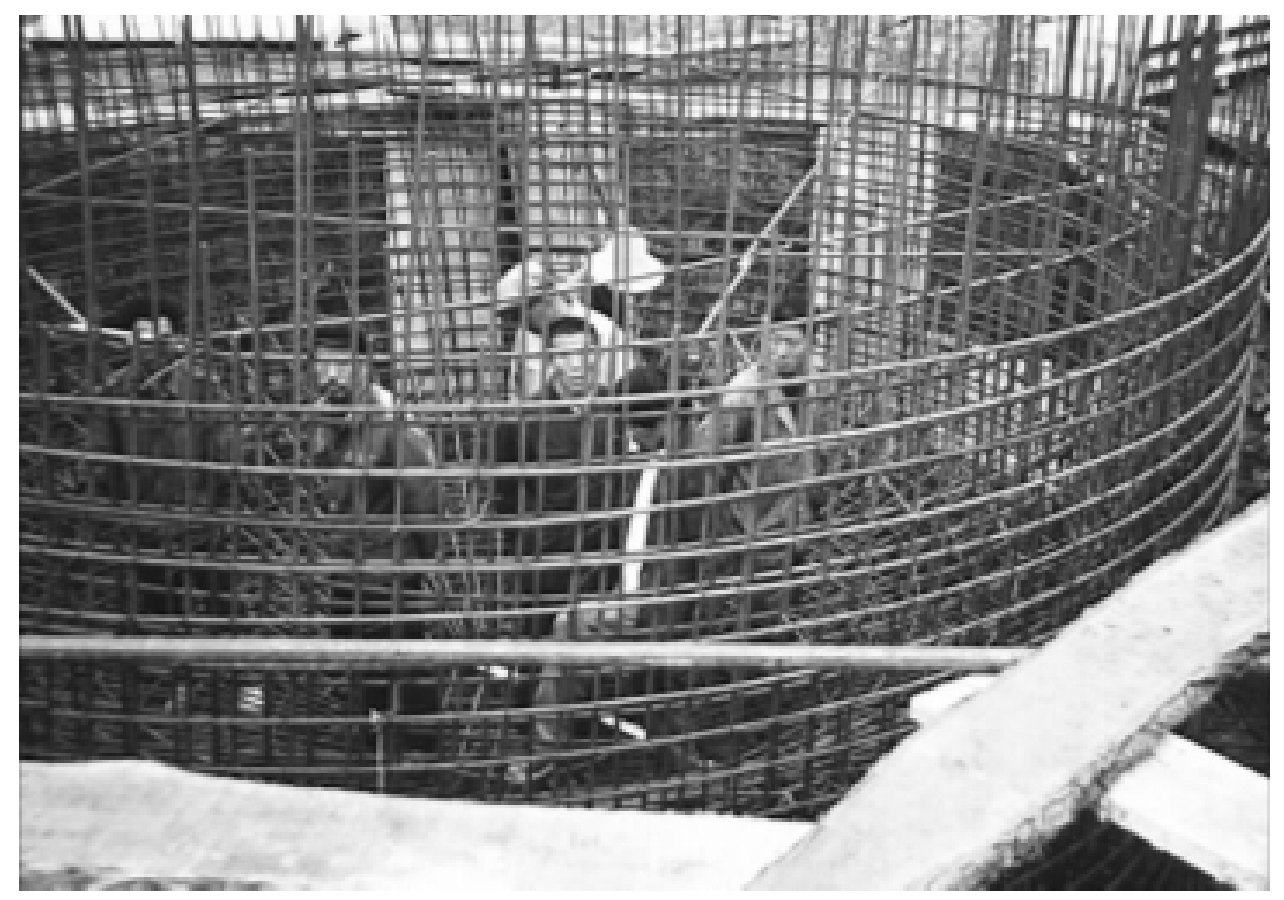

Figure 8. Collection tank under construction for biomass system 


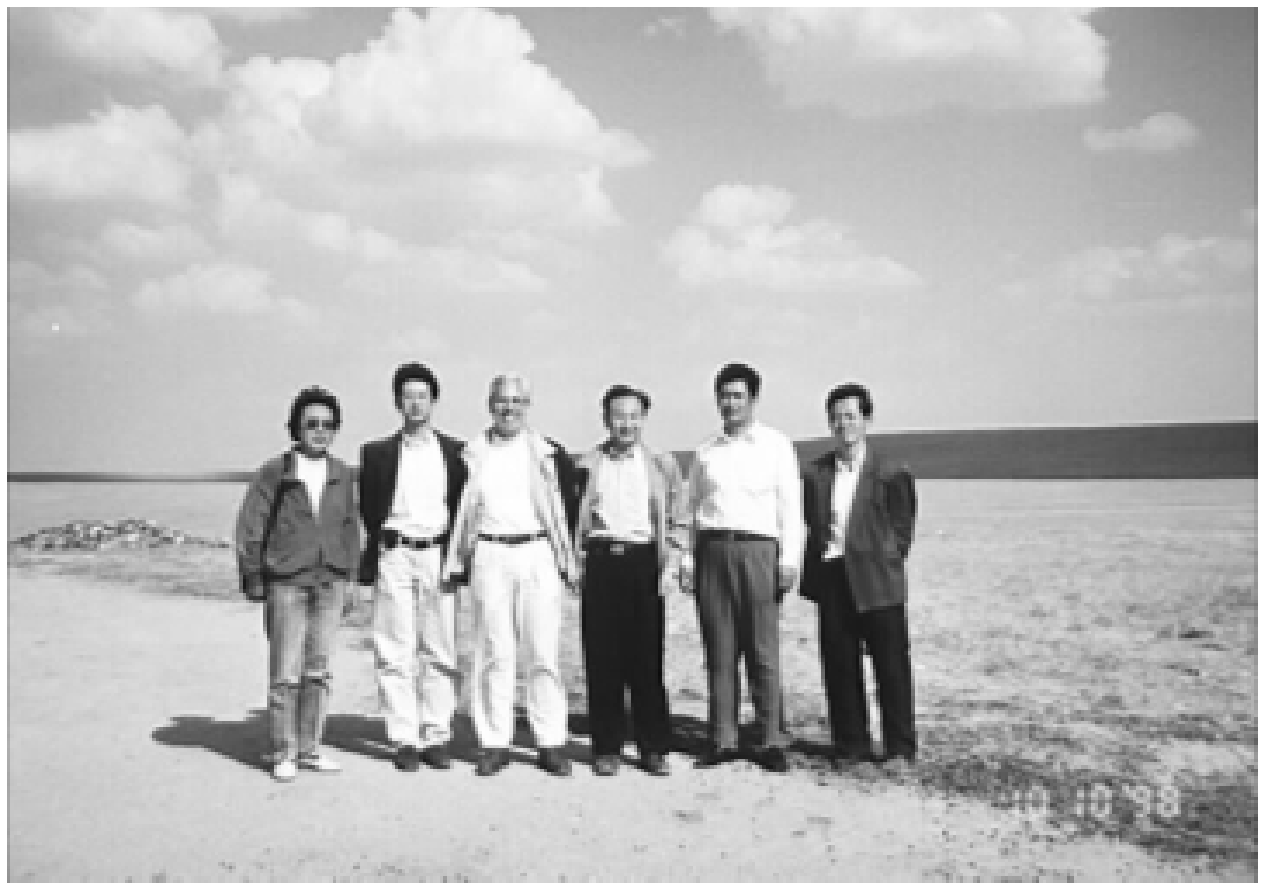

Figure 9. Inner Mongolia site visit team

to the integrator, who designs the system, acquires or builds the necessary inverters and controllers, and eventually installs the system and provides the guarantee and after-sales service. Small teams from the system integrator may then travel to a remote location in say, Tibet, become acclimated to the altitude, and then remain in that region for an extended period of time to complete the installation. As with any contract style of business, the annual demand is inherently unpredictable. In addition, given the extent of national and provincial government dependence, it is unrealistic to think of significantly enhancing this market demand in the short term other than by the addition of bilateral or multilateral programs.

\section{Product Quality and Affordability}

The use of circuit designs that are found to work in the laboratory, coupled with the purchase of off-spec components, no quality control, and no real customer feedback, may improve short-term profitability but will certainly damage the market in the long run. The small distributors tend to assemble the charge regulators and the dc circuits for the compact fluorescent tubes (see Figure 10), possibly saving \$1-\$3 in comparison with reliably produced components available in China. At the same time, military-quality electronics manufacturers, which make reliable controllers and dc light circuits (possibly even in the same city as the distributor/integrator) (see Figure 11), have significant production capacity, which is underutilized and may have higher product selling prices developed to support state overheads.

Overall system quality (including the electronics in general), however, seems to be of a high standard; at present, the locally manufactured modules are not causing significant reliability problems. The system specifications do not stipulate that module designs must undergo stringent reliability testing.

The key challenge today, however, given the absence of any significant credit mechanisms and the low and possibly even declining level of income of some potential rural customers, is providing an affordable PV product. Although the distributors have moved over time to even lower power levels $(<6$-W SHS), the 


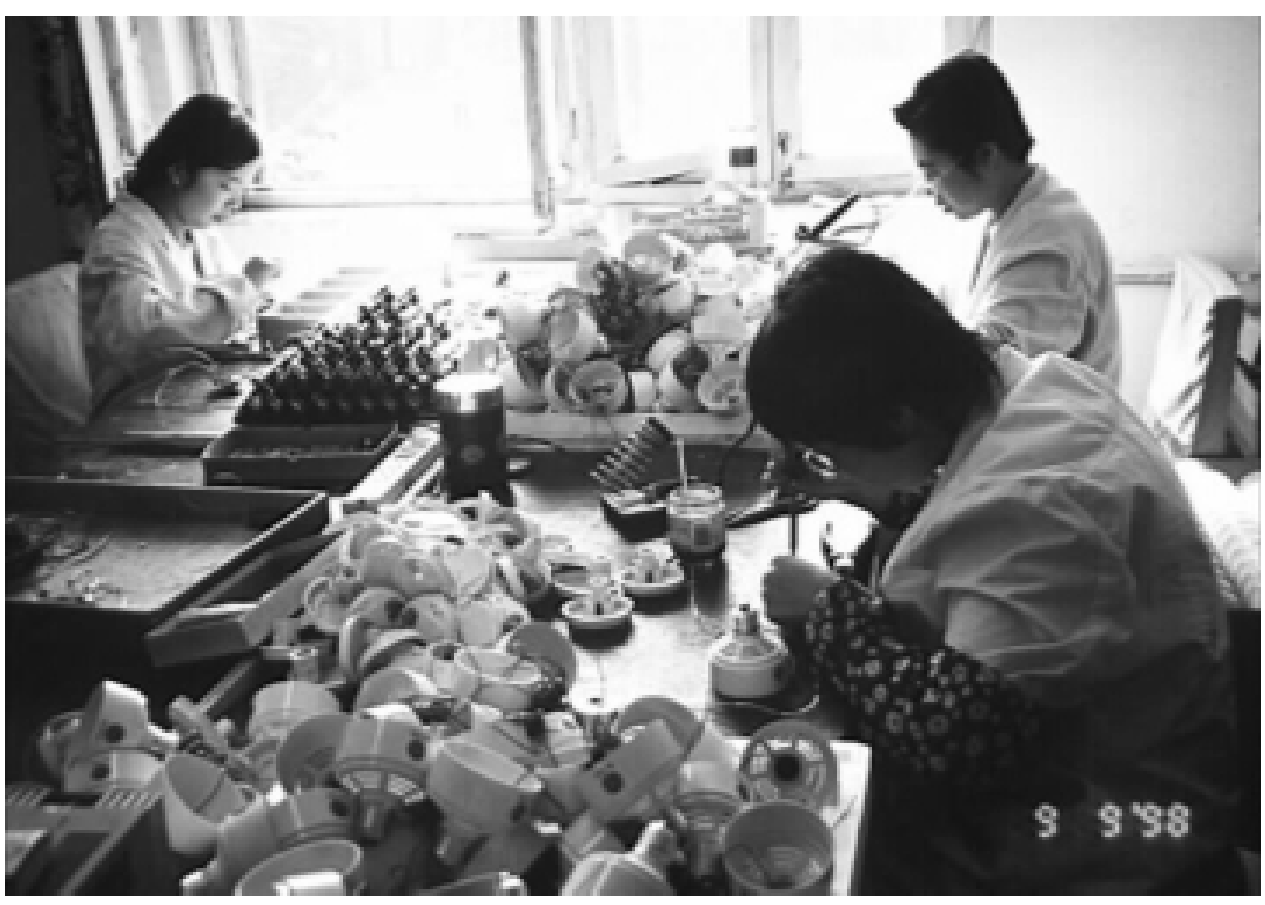

Figure 10. Local circuit assembly

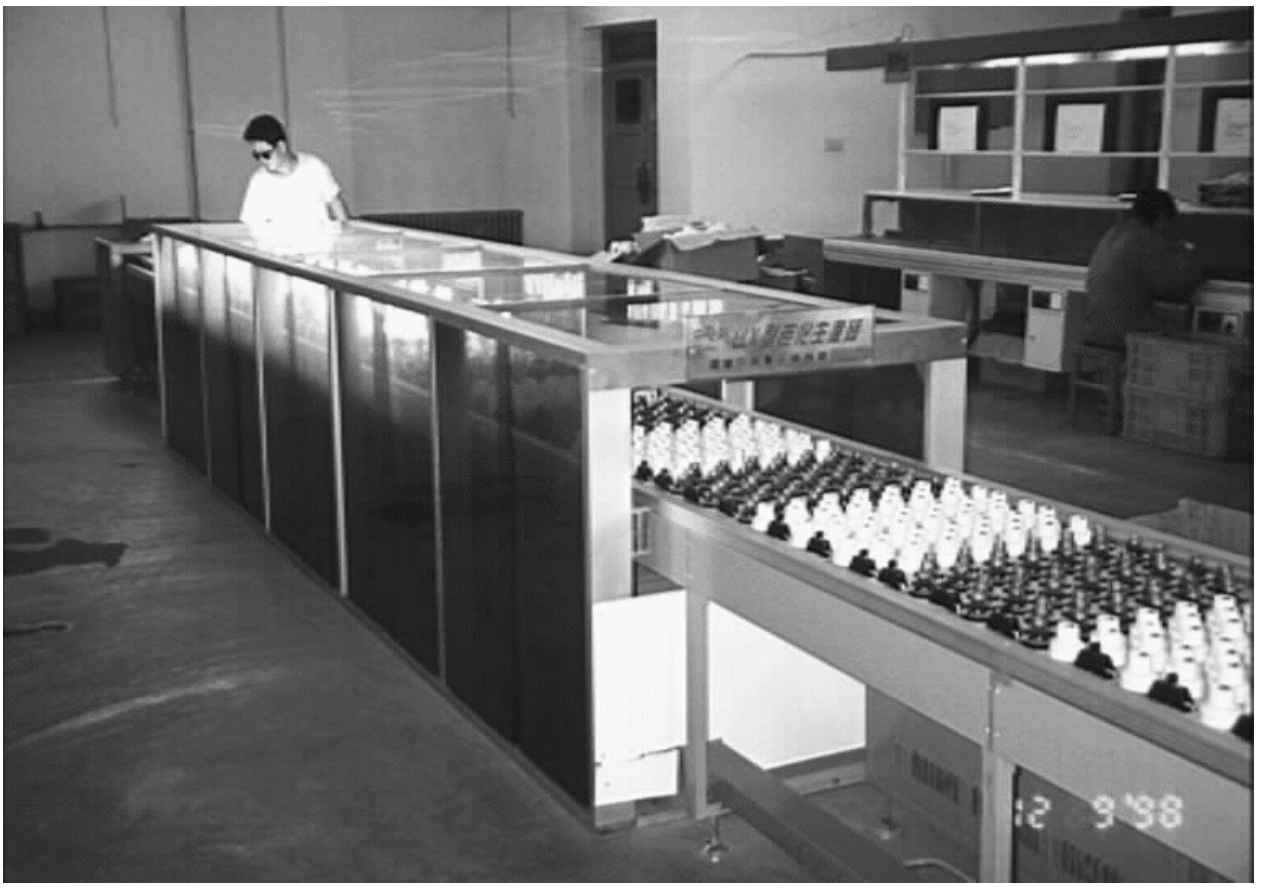

Figure 11. Scale production of CFLs 
transaction costs and any after-sales service costs remain essentially fixed; ultimately, the end customer will find the modest power insufficient. One innovative distributor has developed a "trade-up" approach: when the customer has outgrown the initial small system, they can trade it in against the purchase of the next larger system. This distribution concept addresses the fact that the customer will probably amass more money over time and wish that they had purchased a larger system. However, the total cost of reselling the used system (possibly at a discount) and the additional transaction costs of re-servicing the initial customer, plus any reliability implications of the sale of the used unit, must ultimately be covered by the rural customer's limited resources. If the PV system reliability and sales margins are both high and unit transaction costs for remote individual rural customers can be kept low relative to product costs, then this approach may prove viable.

\section{PV Manufacturing in China}

\section{Overview of Existing Facilities/Capacity}

Despite the modest size of the current PV market in China, there are four comprehensive crystalline module factories, two module assembly plants, and two amorphous silicon (a-Si) thin-film module plants. Much of the major equipment for the photovoltaic plants originated in the United States and was imported in the 1980s. The crystalline-processing capacity is approximately $2.5 \mathrm{MW}$; the two a-Si (Chronar origin) plants are each $1 \mathrm{MW}$ in capacity. Typical process equipment from several of the operational PV plants in China is depicted in Figures 12, 13, and 14. Single-crystal processing is significantly (at least five years) behind the cuttingedge processes used in the major international PV plants. There were no wire saws in

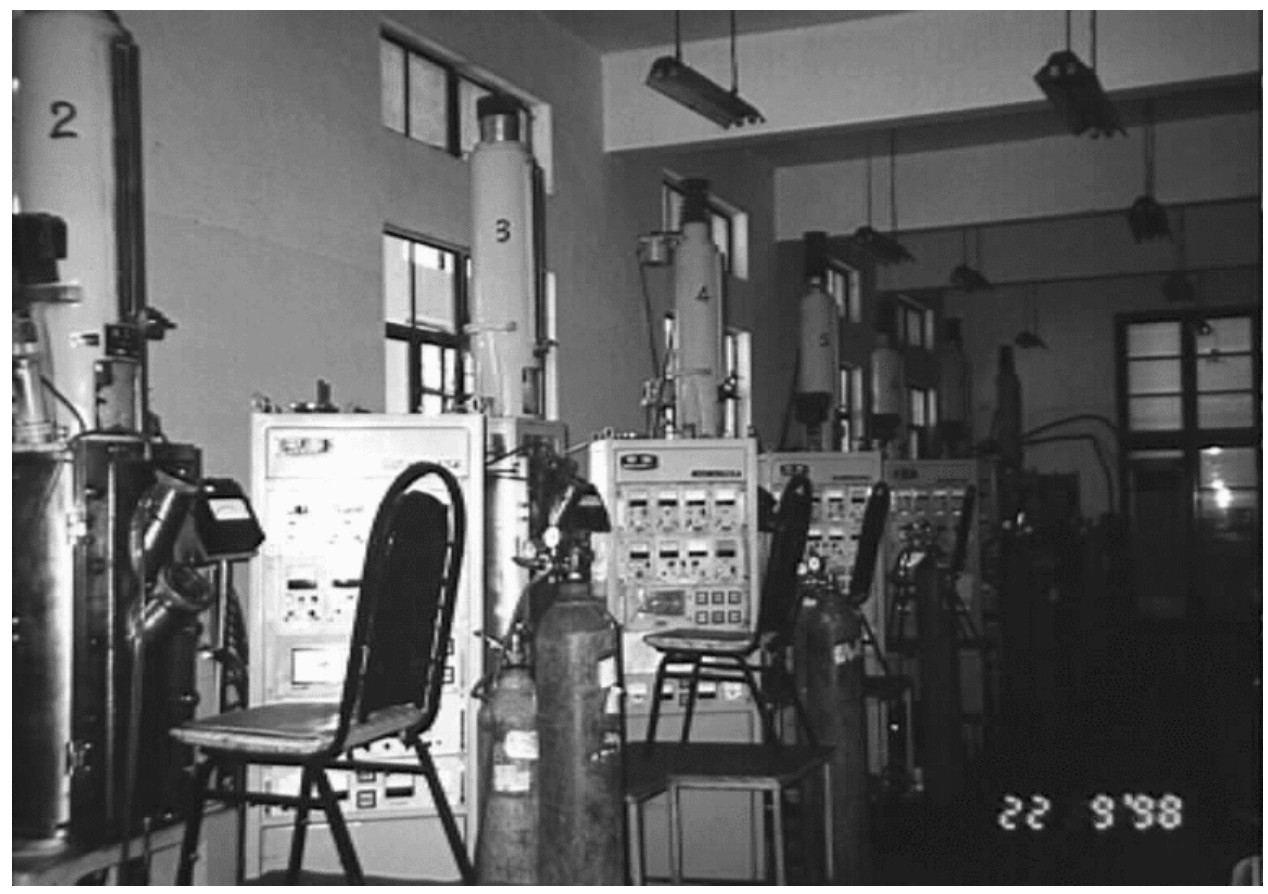

Figure 12. Typical crystal-puller facility 


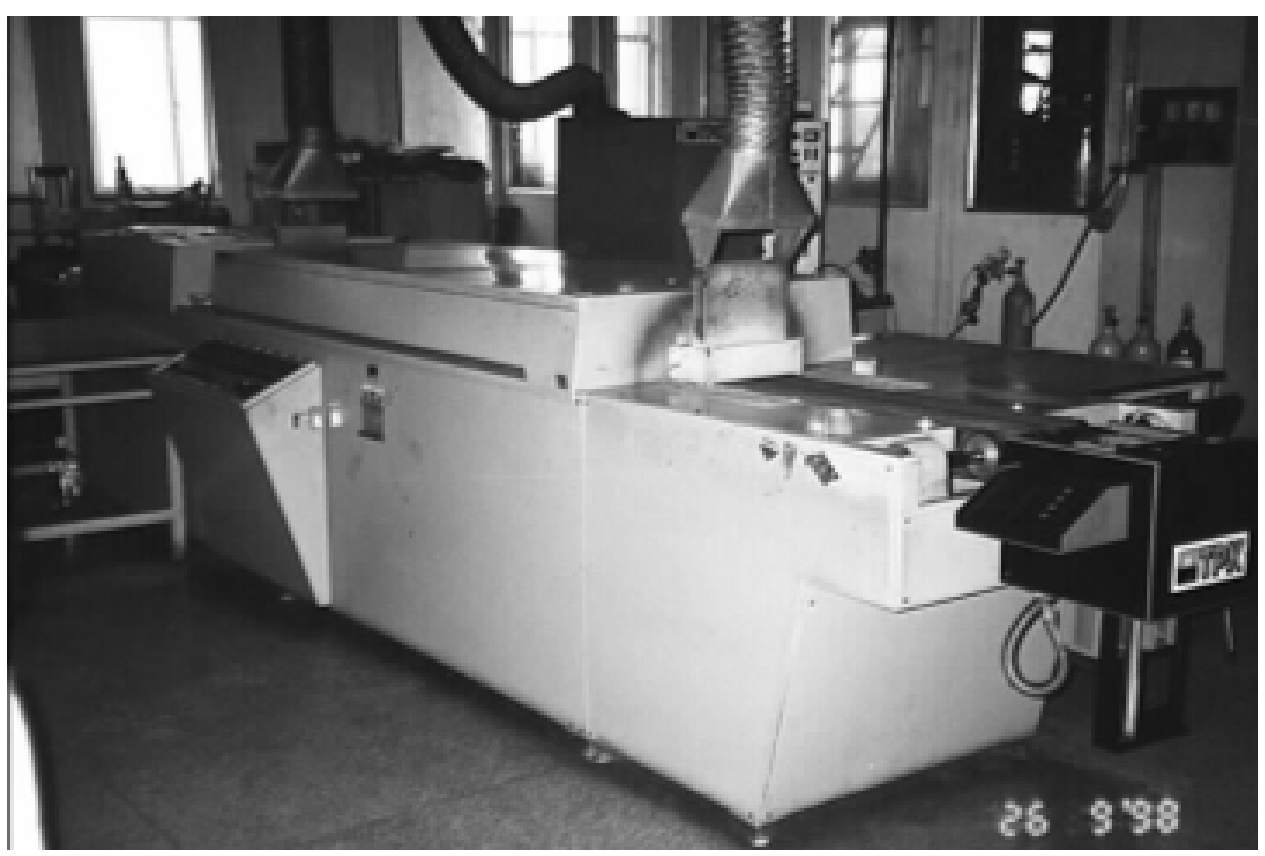

Figure 13. Automated cell processing

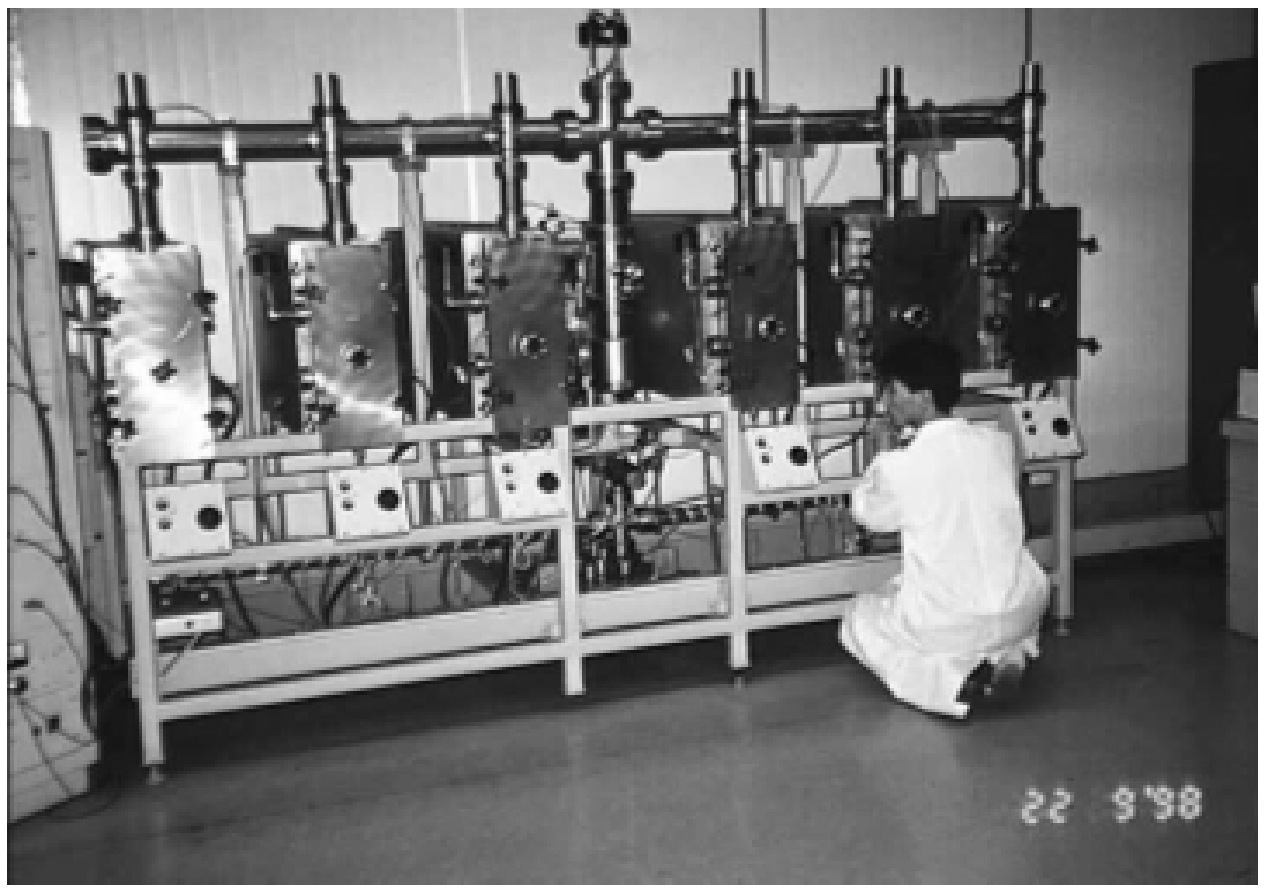

Figure 14. Amorphous silicon deposition chambers 
evidence, and low-voltage small-diameter cells were used for much of the production at one plant. Also, as one might expect, given the cost of labor, the introduction of automation was somewhat limited. Many of the required small (low-wattage) PV modules were assembled mainly by hand. Most of the crystalline plants are operating on a one-shift basis, with elements of the processing such as crystal pulling and wafering run on a multi-shift basis. Laminators and solar testers with the familiar Spire logos were much in evidence, as were some new processing equipment and pullers of Chinese origin.

Neither of the two crystalline assembly plants were visited during the trip; however, the modules that are contract-assembled for Shenzhen Nenglian Electronic Company, Ltd., look and perform like modules purchased directly from Siemens. The amorphous silicon plant in Shenzhen, despite rumors to the contrary, was in operation, albeit at much reduced capacity and quality. The a-Si deposition equipment (see Figure 14) looks and runs well; however, the plant seems to lack not only essential spare parts to maintain the process in good working order, but also the qualified technical effort essential for achieving and maintaining even modest product-quality levels. The Harbin a-Si plant, which is of a somewhat older vintage than had originally been assumed, most likely operates in a similar manner.

An example of the first demonstration array resulting from the Alpha Solarco joint venture (JV) (established to transfer the $\mathrm{x} 400$ concentrator technology) is shown in Figure 15. This technology will be installed at one village site in Tibet in 1999. An example of an indigenous crystalline array that has successfully survived a corrosive environment for five years (with some discoloration of the ethylene vinyl acetate [EVA]) is given in Figure 16.

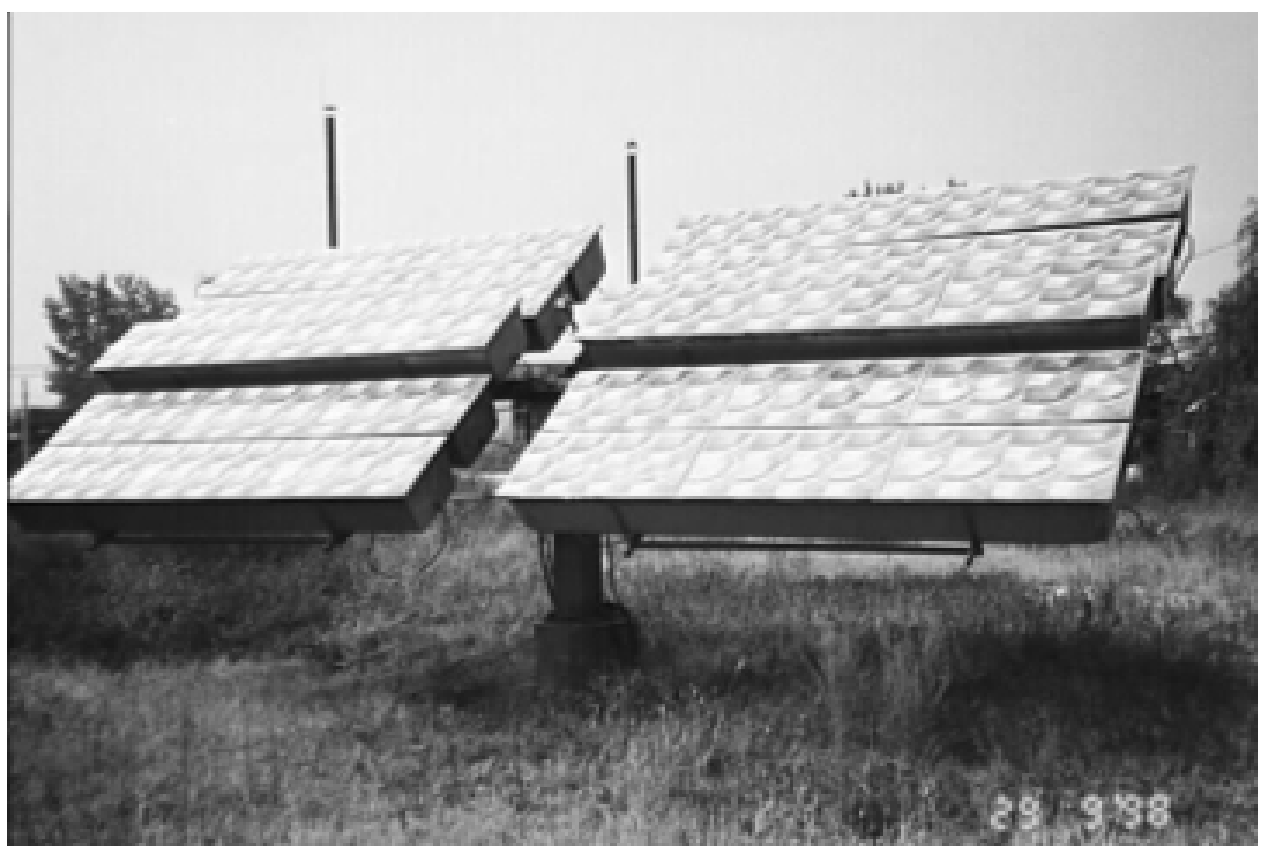

Figure 15. Qinhuangdao concentrator array 


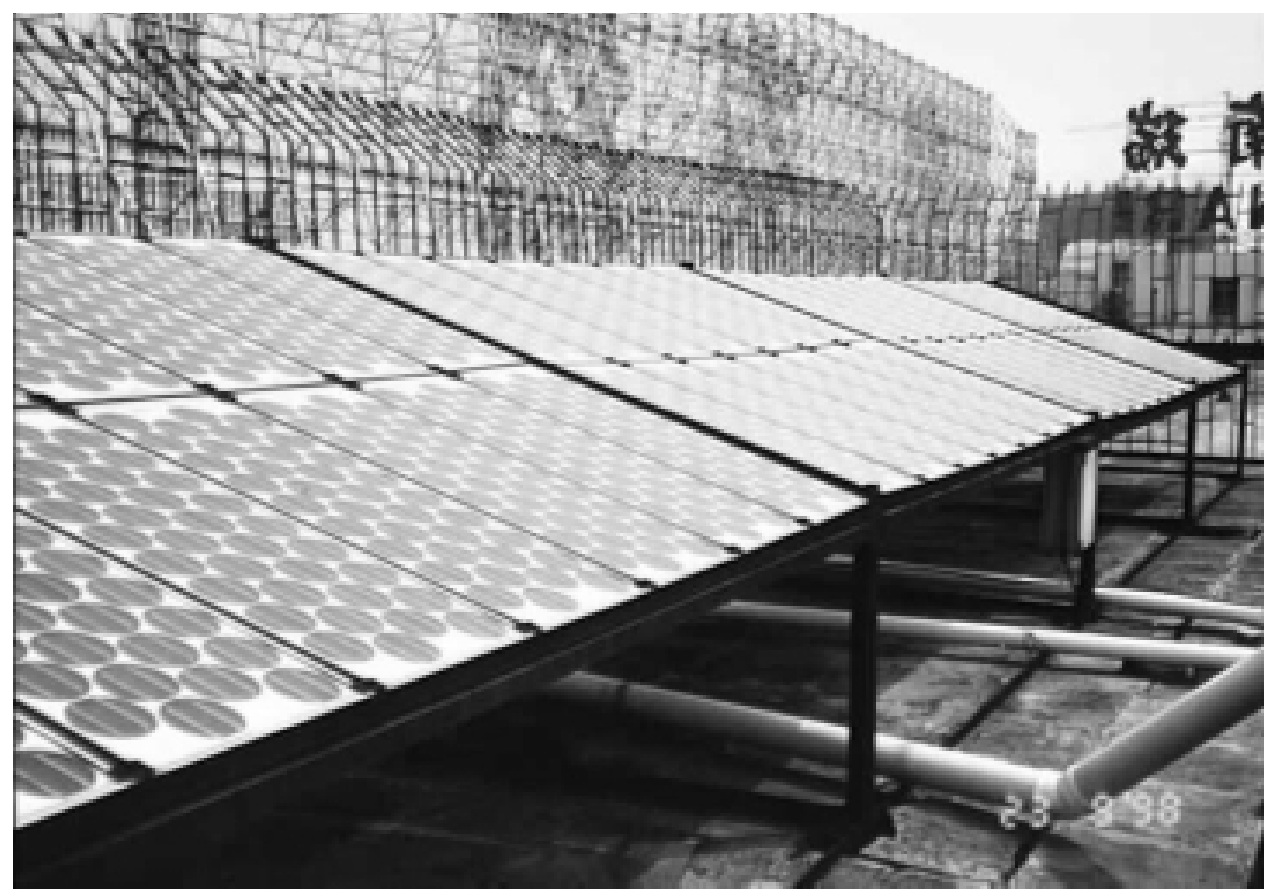

Figure 16. Shenzhen roof-mounted array

\section{Exploring Technology Options and Opportunities}

Each of the operational crystalline silicon plants is in need of significant technical update if they are to ultimately compete with international vendors. The gap between Chinese manufacturers and the world's leading manufacturers, in terms of technological advancement and production volumes, is clearly widening; there is a risk that, as and when the Chinese PV market is scaled up, international suppliers could either dominate it from offshore or establish local plants without needing to collaborate with the existing, possibly outdated, Chinese plants. This scenario obviously assumes that the Chinese authorities would not block such efforts.

There is some evidence that polysilicon casting and wafer processing may be introduced in the next several years to avoid front-end bottlenecks and reduce, to a certain extent, cell costs. Meanwhile, there are many challenges and opportunities on the thin-film front. Indeed, after reviewing the current PV markets in China, we concluded that from a technoeconomic standpoint, a quality thin-film process would offer the best solution. Unfortunately, given the nature of the material produced today by the two existing thin-film plants in China, most if not all of their output is exported, and none of it was evident in any of the small SHSs. Indeed, the upcoming Global Environment Facility (GEF)/World Bank program for China has specifically excluded thin films, despite their obvious inherent performance advantages.

\section{Future Challenges}

Given the status of PV research and development in the Chinese institutes coupled with their own need to sell product to survive, and the sheer cost of updating the existing PV industry, the only realistic hope for a significant manufacturing technology advance would be through the establishment of joint ventures with the United States (or other recognized international leaders), or in some bilateral/multilateral initiative tailored to solve this growing problem. 
Some of the principal challenges facing the Chinese PV manufacturing sector are as follows:

- Improve the quality of the product produced by one or both of the a-Si plants in China so that it can meet international performance standards.

- Begin to establish good thin-film performance with SHSs in northwest China using existing, quality thinfilm product available from several U.S. manufacturers.

- Encourage the World Bank to reword the specifications to focus on established performance and reliability standards rather than a blanket exclusion of thin films.

Given the average income levels of many of the more than 70 million Chinese who have no electricity, as well as the current market trend towards low-wattage SHSs, solving the three challenges listed above should result in future market opportunities of $>5 \mathrm{MW}$ per annum for any indigenous and overseas quality thin-film plants.

\section{PV Businesses in China}

Each of the commercial PV businesses we visited during this trip were asked to respond to a questionnaire that had been supplied prior to the visits. The results of the survey - which have been transcribed into individual tables - are included in this section of the report. (Note: Whenever competitive commercial businesses are asked to respond to market share and total annual sales questions, their responses might be subject to some exaggeration; however, having in many instances toured the plants and evaluated their throughput, we are reasonably confident that the numbers are essentially accurate.)

Most of the businesses were modestly profitable but financially limited. All of the PV manufacturers were running significantly below capacity, despite the evident excess consumer demand for SHSs within China and significant export opportunities for reasonably priced, quality PV modules. Judging by the average margins and the level of excess capacity of the various plants, access to additional funds at reasonable interest rates would provide an opportunity to further increase profitability. In one particular instance, one of the PV plants (backed by a reliable letter of credit) had to turn down export business that was equal in value to all the shipments that it had made in China in that year.

Most of the technology companies expressed a desire to collaborate with U.S. firms, either in the PV or BOS area; however, they had little detailed knowledge of the capabilities of specific U.S. companies nor any regular contact with U.S. PV or BOS firms. Most if not all of the distributor/integrator companies were convinced that their homemade circuits were not only more cost effective, but at least as reliable as the professionally manufactured circuits supplied by the quality conscious, professionally managed Chinese factories.

Many of the distributors/integrators do not currently have the habit of issuing formal supply invoices to their customers. Nor do they pay taxes. In some instances, due to their size, they may not be required to formally register and pay taxes.

All of the small SHS distributors and most of the PV module manufacturers expressed hope that the upcoming GEF/World Bank program would help their businesses, either by providing a modest subsidy to the system supplier ( $\$ 1.50 /$ watt per system) or by improving the viability of the distributors (thereby improving the health of the module suppliers' main customers). To date, there seems to be little understanding of the need for the existing distributors to:

- Opt for buying qualified system components at higher initial costs or significantly enhancing their own technical and production staff, in order to be able to make reliable systems. 
- Install quality control procedures consistent with trying to produce quality systems.

- Establish customer service and repair infrastructures to fulfill the required product and service guarantees essentially required by the GEF program.

- Issue formal invoices to customers in order to ultimately collect the subsidy from the Ministry of Finance, and, in so doing, possibly be required to pay taxes that might offset any subsidy.

Not only do the small distributors need help to improve the quality of their BOS, they also need guidance and assistance in establishing comprehensive service infrastructures to enable a sustainable market to be developed in the midterm.

The industrial systems firms are subject to the unpredictable nature of the contract business, particularly at this early stage of PV market development in China when volumes are small. Their main technical needs are not in modules, but more in the BOS aspects of the latest, most efficient systems. Although there is a need for gridinteractive PV systems and sophisticated hybrid controllers, there is little evidence of suitable technology having been developed in China for either of these applications.

\section{New PV-Related Programs in China}

Currently, there are several sizeable PV-specific or PV-related programs that are under development for China that can be expected to significantly change the size and character of the PV markets and business in China in the next few years. The key programs will be outlined here for completeness; however, comprehensive details on these programs should be available from the agencies listed.

\section{GEF/World Bank and UNDP}

The World Bank/GEF Renewable Energy Project for China, which was scheduled to begin around June 1999, includes $190 \mathrm{MW}$ of grid-connected wind farms and $10 \mathrm{MW}$ of PV SHSs, together with technology assistance for local production of both PV and wind and technical assistance for commercial development. The total budget is more than $\$ 390$ million. The GEF/United Nations Development Programme (UNDP) Renewable Energy Project, which (like the World Bank Project) may begin before June 1999, involves capacity building for promoting commercialization, as well as technology demonstration. The budget for this program is $\$ 26$ million.

Currently, the target regions for the sale/installation of the PV systems are limited to the following six provinces/autonomous regions: Qinghai, Xinjiang, Gansu, Inner Mongolia, the west part of Sichuan, and Tibet. Given the likely concentration of a planned Dutch aid program for installing PV systems in the autonomous region of Xinjiang, there is a possibility that the World Bank project would favor the remaining five regions rather than "competing" with the extensive Dutch PV system program in Xinjiang.

As to eligibility for the GEF/World Bank project, the following users would be the focus: rural households, rural schools, rural hospitals, village head offices, and other village facilities. The PV systems can be $10 \mathrm{~W}_{\mathrm{p}}$ and above, together with wind and PV hybrids for households and 2-kW PV stations for non-household use. The focus is on the distributors; however, in order to help them to develop their business plans and to use qualified components in their systems, they may become eligible for a $\$ 1.50 / \mathrm{W}_{\mathrm{p}}$ subsidy on systems sold in the target areas. Some fraction of the subsidy (say, 5\%) may be retained till the end of the program to ensure that the suppliers' products perform well and that the distributors honor their guarantees.

Currently, distributors are on the list as being eligible to participate, although it is possible as the program progresses that this list might be reduced if firms cannot meet the required performance objectives. It is 
envisaged that the $10 \mathrm{MW}$ of PV will be installed over a period of five years. If the project creates additional business, this would double the annual demand for PV in China during the project.

The large-scale, grid-connected wind systems will be installed in four provinces on preselected sites. Power purchase agreements (PPAs) are already in place for the specific sites. The required turbines are to be $\sim 300 \mathrm{~kW}$ per unit and the selling price of the generated electricity will be between 0.7 and $0.62 \mathrm{RMB}$ (Renminbi, or "People's Money")/kilowatt-hour, depending on the site and its known wind resource. (Note-The exchange rate for the Chinese unit of currency is: $\sim 8.3 \mathrm{RMB}=\$ 1$ U.S.)

\section{The Dutch/Xinjiang Project}

A letter of intent was signed for this project in March 1998. Various feasibility studies are under way involving the supply of 60,000 SHSs to be installed entirely in the province of Xinjiang. The project would entail the provision of Dutch funds to cover $60 \%$ of the cost of the hardware alone; at this time neither the service infrastructure nor the installation costs would be covered. These additional costs would need to be borne locally in China. The PV systems would mainly be between 25 and $50 \mathrm{~W}$. Individual households might be expected to pay between 1,400 and 1,700 RMB per system at the $25-\mathrm{W}$ scale. In addition, a smaller quantity of larger systems are apparently planned for Xinjiang. Shell was apparently selected to be the PV project company.

Nevertheless, there is considerable concern in the Chinese PV community that this project might eventually involve excessive subsidies at the point of sale, which would inevitably distort the PV market in the northwestern provinces. Those in the community fear that this would negatively impact their own modest margins.

Although this project may not add to the market for indigenous modules (because these would almost certainly come from Holland/Europe), it might be expected to have significant local resource implications for the modest-scale, quality system integrators/installers and the suppliers of reliable BOS.

\section{The Brightness Program}

In 1996, the State Development and Planning Commission launched the Brightness Program, with the overall objective of providing renewable power for lighting the rural unelectrified regions of China. The overarching target is to supply 20 million Chinese with small renewable systems by the year 2010. Although this program has adopted a considerable challenge, it has yet to be matched with adequate money to achieve these goals. However, ongoing programs within the individual provinces that adopt their regional goals, and any international collaboration programs that focus on renewables for rural areas, are being counted within the umbrella of this Brightness Program.

\section{Conclusions}

- The status of PV manufacturing technology in China today is significantly (5 to 10 years) behind that of the West.

- The reliability of the modules from most of the manufacturers in China is not currently a pressing problem.

- Technology updates for the Chinese PV industry are not readily available from either provincial or national institutes, which are currently being encouraged to manufacture and sell products in competition with the very industries that need their help. 
- There is an overwhelming desire to collaborate with the U.S. PV industry in order to update PV technology and develop its vast market potential; however, there is neither a clear understanding of the range of U.S. PV companies and their technologies, nor of their specific competitive strengths and weaknesses.

- In general, the "manufacture" of charge regulators, inverters, and dc light ballasts by 10-50-person distributor/integrator operations with limited experience is considered to be the least reliable aspect of the PV industry in China.

- The larger scale, professionally designed, quality controlled, manufactured product currently being produced in China is considered too expensive by distributors, which have opted to make their own. The real costs of any lack of reliability are probably borne by the end-use customers.

- The emphasis on low-cost systems assembled by distributors/integrators competing solely on the basis of price leads to the adoption of poor or unsuitable storage batteries, which, in turn, results in short battery life.

- The PV markets are currently dominated by small $(\sim 10-\mathrm{W})$, semiportable solar home systems, which are sold to widely dispersed rural customers, with little or no service infrastructure.

- Because of the limited resources of the majority of the distributors, the critical service infrastructure required to serve the remote markets has not been developed.

- The majority of existing and potential end users are ill equipped, at this stage, to make informed system choices.

- At this fragile stage of market development, there is a need for a buffer between remote, ill-informed rural customers and short-term, commercially motivated suppliers.

- There is a ready cash market today for many tens of thousands of SHSs per annum.

- Most of the current small SHSs that are sold to rural customers will probably fail within a short period (i.e., $<12$ months).

- There is little quantitative data on the reliability of small systems in the remote markets.

- The very nature of the remote rural markets makes the absence of reliability data even more dangerous. No news is not necessarily good news.

- Some innovative credit mechanisms have been successfully applied to the sale of remote SHSs; however, there are many examples of ineffective credit programs.

- At the provincial level there is little knowledge of the critical evaluations undertaken and the experience gained in other parts of the world in adopting PV rather than grid extension as a reliable, appropriate, and more cost-effective way of providing electricity to remote regions. Making this data and experience available in the right form to a broad range of organizations concerned with the provision of services to remote communities, should accelerate the adoption of distributed PV electrification where appropriate.

- The modest module wattage of the majority of the current PV systems sold suggests that thin-film PV technology would be the most appropriate, reliable, and cost-effective choice for manufacturing solar panels. 
- Poor experience with indigenous thin films has stalled the adoption of what is arguably the most appropriate technology. 


\section{Company/Organization Profiles}




\section{Questionnaire}

\section{Renewable Energy (PV Technology) Business and Applications Evaluation}

\section{China: September-October 1998-National Renewable Energy Laboratory (United States) Company/Organization Profiles}

Please answer as many of the following questions as possible regarding your company or organization.

\section{Company Particulars}

1. Name, address, and location of company and name of key managers, directors, or officers including telephone and facsimile numbers and e-mail address.

2. When was the company established? Please provide approximate date.

3. What type of company? Please tell us, for example: state-owned, private-sector, or for-profit company within an institution, or other type.

4. Size of company-annual level of sales (1992-1997). Total number of employees; forecast percentage growth in sales for the next five years?

\section{Company Products or Services}

5. What is company's main business (photovoltaic modules or balance of systems manufacturer, system integrator, distributor, etc.)

6. List products or services offered and any key PV technologies employed.

7. Identify any existing licensing agreements with international PV technology companies.

\section{Markets Served}

8. Identify geographic market regions that your company serves within China and the level of export activity (key territories and the percentage of your annual sales that are exported).

9. Key market segment types served (percentage that goes to telecommunications segment, rural electrification, or other, etc.)

10. Estimate company's percentage share of total available market in the market segments that your company serves.

\section{Key Barriers to Profitably Expanding Your Business}

Please identify the main barriers that your business sees:

11. Financial resources, customer credit facilities, lack of customer awareness, absence of effective distribution channels, component of system reliability, lack of advanced or competitive technology, insufficient trained personnel or other reason. (List most important to your business.)

\section{Partnership Objectives}

12. Please indicate if your company or organization is partnering with a U.S. business or organization.

13. Is your company interested in partnering with a U.S. concern?

14. What type of technology, product, service or resource would your company be most interested in accessing via a U.S. partner organization or firm?

15. Specify preferred type of business relationship (joint venture, licensing, investment, etc.)

16. In the event that such a relationship would require significant investment, please identify where your company would find the financial resources to share in the investment. 


\section{Previous Experience with U.S. Collaboration}

17. Identify nature of any previous or ongoing collaborations with U.S. concerns in the area of PV technology or business.

\section{The Following Questions are for PV Module Manufacturers}

18. What PV technology do you use? Single-crystal silicon, polycrystalline, amorphous silicon, or other?

19. What part of the module process does your company undertake? Wafer fabrication, cell processing, module assembly?

20. How big are the modules that you typically produce in peak watts per module?

21. How many modules did your company produce last year (1997) in total peak watts?

22. What reliability testing do your modules undergo?

23. What is the longest time (in years) that you have had modules working continuously in the field?

24. What do you find the least reliable part of the systems that your modules are used in, for example, the charge regulators, the batteries, the fluorescent-light ballasts or others? Please indicate. 


\section{Company Profiles}

\begin{tabular}{|c|c|c|}
\hline 1 & Company Name & Alpha Solar Energy Power Company, Ltd.-Qinhuangdao, Hebei \\
\hline 2 & When Established & 1990 \\
\hline 3 & Type & State joint venture (JV) with U.S. Alpha Solarco plus minor share owned by Hong Kong R\&D company. \\
\hline 4 & Size of Company & Original investment $\sim \$ 4$ million (U.S.). $<20$ employees. \\
\hline 5 & Main Business & PV concentrators. \\
\hline 6 & Products & Current scale of Chinese PV markets does not suit concentrator technology. \\
\hline 7 & Existing Licenses & Inactive partnership with Alpha Solarco due to major funding difficulties. \\
\hline 8 & Which Geographical Markets Served & Demo concentrator array for Tibet-expressed interest in export markets. \\
\hline 9 & Key Market Segments Served & Could serve professional segment if technology ready and markets develop towards larger systems. \\
\hline 10 & $\%$ Share of Segments & Zero. \\
\hline 11 & Main Barriers & Outdated technology, lack of funds \& technical assistance, no appreciation of concentrator strengths. \\
\hline 12 & Current Relationship with U.S. Firm & Inactive relationship with JV partner due to financial stress. \\
\hline 13 & Interested in Partnering with U.S. Firm & Not their main focus at present. \\
\hline 14 & Technology, Product, or Service Sought & Need to understand how best to market their current strengths. \\
\hline 15 & Preferred Type of Relationship & An active $\mathrm{JV}$. \\
\hline 16 & Where Can They Find Financing & Funding currently being provided by state enterprise but coming to an end if no improvement. \\
\hline 17 & Nature of Existing Relationship with U.S. & Lapsed. \\
\hline 18 & Which PV Technology is Used & Alpha Solarco concentrator technology (X 400). \\
\hline 19 & Which Part of the Module Process & Import, Fresnel lenses and custom tape. \\
\hline 20 & Size of Typical Modules & 150-W concentrators plus small SHS with purchased flat-plate modules $(8-12 \mathrm{~W})$. \\
\hline 21 & Output in 1997 Watts Peak & $\sim 15-\mathrm{kW}$ demo unit for Tibet. \\
\hline 22 & Reliability Testing Done & In-house and demo unit on site. \\
\hline 23 & How Long Have Modules Operated & 3 years for on-site array. \\
\hline 24 & Least Reliable System Component & Batteries and electronics. \\
\hline
\end{tabular}




\section{Company Profiles (Continued)}

\begin{tabular}{|c|c|c|}
\hline 1 & Company Name & Beijing General Research Institute for Non-Ferrous Metals-PV Group (Beijing). \\
\hline 2 & When Established & Began selling 1985. \\
\hline 3 & Type & State institution, mainly research. \\
\hline 4 & Size of Company & PV group very small ( $\sim 15$ people). Total sales $\sim 20 \mathrm{~kW}, \sim 0.8$ million RMB. \\
\hline 5 & Main Business & Research in PV crystalline and thin film. PV sales help cover salaries. \\
\hline 6 & Products & Small modules and SHSs. \\
\hline 7 & Existing Licenses & None. \\
\hline 8 & Which Geographical Markets Served & Northwestern provinces. \\
\hline 9 & Key Market Segments Served & SHS distributor-rural unelectrified homes. \\
\hline 10 & $\%$ Share of Segments & $5 \%$. \\
\hline 11 & Main Barriers & Keeping volume low so as to avoid head-on competition with main industry players. \\
\hline 12 & Current Relationship with U.S. Firm & Valued adviser to U.S./NREL/DOE and to Chinese government and industry. \\
\hline 13 & Interested in Partnering with U.S. Firm & N/A. \\
\hline 14 & Technology, Product, or Service Sought & None. \\
\hline 15 & Preferred Type of Relationship & - \\
\hline 16 & Where Can They Find Financing & - \\
\hline 17 & Nature of Existing Relationship with U.S. & - \\
\hline 18 & Which PV Technology is Used & Single-crystal production and a-Si research scale. \\
\hline 19 & Which Part of the Module Process & Pullers to finished modules. \\
\hline 20 & Size of Typical Modules & 20 watt. \\
\hline 21 & Output in 1997 Watts Peak & $20 \mathrm{~kW}$. \\
\hline 22 & Reliability Testing Done & In-house and related institutes. \\
\hline 23 & How Long Have Modules Operated & $>5$ years. \\
\hline 24 & Least Reliable System Component & Electronics-BOS. \\
\hline
\end{tabular}


Company Profiles (Continued)

\begin{tabular}{|c|c|c|}
\hline 1 & Company Name & $\begin{array}{l}\text { Jike Energy New Technology Development Company of Beijing. Ministry of Electronic Industries- } \\
\text { Beijing. }\end{array}$ \\
\hline 2 & When Established & 1982 \\
\hline 3 & Type & State owned. \\
\hline 4 & Size of Company & $200 \mathrm{~kW}$ per annum of system sales, 12 staff, 10 million RMB sales per annum depending on contracts. \\
\hline 5 & Main Business & Professional systems sales and installation. Uses other suppliers' modules. \\
\hline 6 & Products & Telecommunications power systems, industrial power units, and some rural electrification. \\
\hline 7 & Existing Licenses & None. \\
\hline 8 & Which Geographical Markets Served & Tibet, and remainder of northwestern China and northeast China. \\
\hline 9 & Key Market Segments Served & Communications 50\%, industrial 10\%, rural electrification $40 \%$. \\
\hline 10 & $\%$ Share of Segments & Professional, large-scale $60 \%$, rural SHS $10 \%$. \\
\hline 11 & Main Barriers & Major systems depend on state funding. \\
\hline 12 & Current Relationship with U.S. Firm & Customer for some modules. \\
\hline 13 & Interested in Partnering with U.S. Firm & Yes. \\
\hline 14 & Technology, Product, or Service Sought & Broaden systems capability, including grid interactive and hybrid. \\
\hline 15 & Preferred Type of Relationship & JV investment. \\
\hline 16 & Where Can They Find Financing & Not clear. \\
\hline 17 & Nature of Existing Relationship with U.S. & Participant in DOE/Inner Mongolia projects. Customer for U.S./German modules. \\
\hline 18 & Which PV Technology is Used & N/A. Not PV manufacturer. \\
\hline 19 & Which Part of the Module Process & - \\
\hline 20 & Size of Typical Modules & - \\
\hline 21 & Output in 1997 Watts Peak & - \\
\hline 22 & Reliability Testing Done & - \\
\hline 23 & How Long Have Modules Operated & - \\
\hline 24 & Least Reliable System Component & - \\
\hline
\end{tabular}




\section{Company Profiles (Continued)}

\begin{tabular}{|c|c|c|}
\hline 1 & Company Name & Beijing New Building Materials Company, Ltd.-Beijing. \\
\hline 2 & When Established & 10 plus years ago. \\
\hline 3 & Type & State-owned-100-500 related companies. \\
\hline 4 & Size of Company & $600-800$ million RMB (just the local units). \\
\hline 5 & Main Business & All aspects of building materials to complete factory-built homes. \\
\hline 6 & Products & Roof struts, windows, wall materials, doors, cladding materials, etc. \\
\hline 7 & Existing Licenses & None in PV area. \\
\hline 8 & Which Geographical Markets Served & Throughout all of China. \\
\hline 9 & Key Market Segments Served & Building industry. \\
\hline 10 & $\%$ Share of Segments & Unknown; however, probably dominant in chosen markets. \\
\hline 11 & Main Barriers & Wants to enter PV after studying it for 5 years. \\
\hline 12 & Current Relationship with U.S. Firm & Distributor for Solarex modules. \\
\hline 13 & Interested in Partnering with U.S. Firm & Yes. \\
\hline 14 & Technology, Product, or Service Sought & PV technology. \\
\hline 15 & Preferred Type of Relationship & Some form of PV venture after sufficient market development. \\
\hline 16 & Where Can They Find Financing & Does not seem to be a problem. \\
\hline 17 & Nature of Existing Relationship with U.S. & Distribution and project development. \\
\hline 18 & Which PV Technology is Used & Has crystalline PV roof tiles on solar building. \\
\hline 19 & Which Part of the Module Process & - \\
\hline 20 & Size of Typical Modules & - \\
\hline 21 & Output in 1997 Watts Peak & - \\
\hline 22 & Reliability Testing Done & - \\
\hline 23 & How Long Have Modules Operated & - \\
\hline 24 & Least Reliable System Component & - \\
\hline
\end{tabular}




\section{Company Profiles (Continued)}

\begin{tabular}{|c|c|c|}
\hline 1 & Company Name & Beijing Solar Energy Research Center-Beijing. \\
\hline 2 & When Established & Technical company established 1988. \\
\hline 3 & Type & State ownership_-Beijing Municipality, research institute with some manufacturing. \\
\hline 4 & Size of Company & 250 staff, 200 million RMB/annum, produce 100,000 evacuated solar tubes per annum. \\
\hline 5 & Main Business & Producing and selling solar thermal products and efficient stoves. Developing PV production (crystalline). \\
\hline 6 & Products & Solar thermal collectors, efficient stoves. \\
\hline 7 & Existing Licenses & None. \\
\hline 8 & Which Geographical Markets Served & Throughout China. \\
\hline 9 & Key Market Segments Served & Solar thermal water heaters (institutions and homes), rural cook stoves. \\
\hline 10 & $\%$ Share of Segments & $\sim 40 \%$ solar thermal, $15 \%$ stoves. \\
\hline 11 & Main Barriers & Market development and PV technology development. \\
\hline 12 & Current Relationship with U.S. Firm & None. \\
\hline 13 & Interested in Partnering with U.S. Firm & Yes. \\
\hline 14 & Technology, Product, or Service Sought & Improved solar thermal efficiencies. \\
\hline 15 & Preferred Type of Relationship & Not known. \\
\hline 16 & Where Can They Find Financing & State resources. \\
\hline 17 & Nature of Existing Relationship with U.S. & None. \\
\hline 18 & Which PV Technology is Used & Single crystal in pilot-scale, front-end only. \\
\hline 19 & Which Part of the Module Process & Pilot cell processing. \\
\hline 20 & Size of Typical Modules & - \\
\hline 21 & Output in 1997 Watts Peak & - \\
\hline 22 & Reliability Testing Done & - \\
\hline 23 & How Long Have Modules Operated & - \\
\hline 24 & Least Reliable System Component & - \\
\hline
\end{tabular}




\section{Company Profiles (Continued)}

\begin{tabular}{|c|c|c|}
\hline 1 & Company Name & Gansu GNERI Solar Electric Power Company, Ltd.-Lanzhou, Gansu. \\
\hline 2 & When Established & 1990 \\
\hline 3 & Type & Collective originally, now stock company ( $80 \%$ owned by ERI, $20 \%$ owned by workers). \\
\hline 4 & Size of Company & 36 people, 600 SHSs/annum, $\sim 1.4$ million RMB per annum. \\
\hline 5 & Main Business & Selling and assembling SHSs and some professional systems. \\
\hline 6 & Products & Small SHSs, communications power units. \\
\hline 7 & Existing Licenses & None. \\
\hline 8 & Which Geographical Markets Served & Gansu, Qinghai, and Inner Mongolia. \\
\hline 9 & Key Market Segments Served & SHS rural electrification, professional. \\
\hline 10 & $\%$ Share of Segments & $10 \%$ SHS, $5 \%$ professional. \\
\hline 11 & Main Barriers & Shortage of capital cost of money to them versus private sector. \\
\hline 12 & Current Relationship with U.S. Firm & None. \\
\hline 13 & Interested in Partnering with U.S. Firm & Does not see any need. \\
\hline 14 & Technology, Product, or Service Sought & None. \\
\hline 15 & Preferred Type of Relationship & - \\
\hline 16 & Where Can They Find Financing & State agency. \\
\hline 17 & Nature of Existing Relationship with U.S. & None. \\
\hline 18 & Which PV Technology is Used & - \\
\hline 19 & Which Part of the Module Process & - \\
\hline 20 & Size of Typical Modules & - \\
\hline 21 & Output in 1997 Watts Peak & - \\
\hline 22 & Reliability Testing Done & - \\
\hline 23 & How Long Have Modules Operated & - \\
\hline 24 & Least Reliable System Component & - \\
\hline
\end{tabular}




\section{Company Profiles (Continued)}

\begin{tabular}{|c|c|c|}
\hline 1 & Company Name & Gansu PV Company, Ltd.-Lanzhou, Gansu. \\
\hline 2 & When Established & 1992 \\
\hline 3 & Type & Private Chinese/U.S. partnership, majority Chinese (51\%). \\
\hline 4 & Size of Company & 3-4,000 small SHSs/annum, $\sim 5$ million RMB per annum sales. \\
\hline 5 & Main Business & SHS sales and assembly. \\
\hline 6 & Products & Portable SHS with trade-up options to move to larger units. \\
\hline 7 & Existing Licenses & None. \\
\hline 8 & Which Geographical Markets Served & Gansu, Qinghai, and Inner Mongolia. \\
\hline 9 & Key Market Segments Served & Rural SHS. \\
\hline 10 & $\%$ Share of Segments & $20 \%$ \\
\hline 11 & Main Barriers & Cost of modules. \\
\hline 12 & Current Relationship with U.S. Firm & Joint venture with Solar Electric Light Fund (SELF). \\
\hline 13 & Interested in Partnering with U.S. Firm & Not at present. \\
\hline 14 & Technology, Product, or Service Sought & - \\
\hline 15 & Preferred Type of Relationship & - \\
\hline 16 & Where Can They Find Financing & - \\
\hline 17 & Nature of Existing Relationship with U.S. & Participation in NREL/Inner Mongolia project, ongoing partnership with SELF. \\
\hline 18 & Which PV Technology is Used & N/A. Not a module manufacturer. \\
\hline 19 & Which Part of the Module Process & - \\
\hline 20 & Size of Typical Modules & - \\
\hline 21 & Output in 1997 Watts Peak & - \\
\hline 22 & Reliability Testing Done & - \\
\hline 23 & How Long Have Modules Operated & - \\
\hline 24 & Least Reliable System Component & - \\
\hline
\end{tabular}




\section{Company Profiles (Continued)}

\begin{tabular}{|c|c|c|}
\hline 1 & Company Name & H.K. Co. Scheme Enterprises Holdings Ltd.-Foshan, Guangdong. \\
\hline 2 & When Established & 1986 \\
\hline 3 & Type & Private technology company with 1 H.K. shareholder, 7 from mainland. Operates under Foshan CST. \\
\hline 4 & Size of Company & 224 people in HQ location, 14 subsidiaries, $\sim 100$ million RMB. \\
\hline 5 & Main Business & Development, production, sales UPS, controllers and inverters. \\
\hline 6 & Products & Inverters 1 kVA-100 kVA, UPSs 1 kVA-200 kVA. \\
\hline 7 & Existing Licenses & None at present. \\
\hline 8 & Which Geographical Markets Served & Throughout China. \\
\hline 9 & Key Market Segments Served & Professional, telecommunications, and remote power. \\
\hline 10 & $\%$ Share of Segments & $15 \%-20 \%$ \\
\hline 11 & Main Barriers & Slump in Chinese economy. \\
\hline 12 & Current Relationship with U.S. Firm & Ongoing with Santak. \\
\hline 13 & Interested in Partnering with U.S. Firm & Yes. \\
\hline 14 & Technology, Product, or Service Sought & Broaden product offering. \\
\hline 15 & Preferred Type of Relationship & Tech transfer, market development. \\
\hline 16 & Where Can They Find Financing & Existing shareholders. \\
\hline 17 & Nature of Existing Relationship with U.S. & Continuing mutually beneficial trading relationship. \\
\hline 18 & Which PV Technology is Used & N/A. Do not make or sell PV. \\
\hline 19 & Which Part of the Module Process & - \\
\hline 20 & Size of Typical Modules & - \\
\hline 21 & Output in 1997 Watts Peak & - \\
\hline 22 & Reliability Testing Done & - \\
\hline 23 & How Long Have Modules Operated & - \\
\hline 24 & Least Reliable System Component & - \\
\hline
\end{tabular}


Company Profiles (Continued)

\begin{tabular}{|c|c|c|}
\hline 1 & Company Name & Inner Mongolia Huade New Technology Company-Hohhot, Inner Mongolia. \\
\hline 2 & When Established & 1993-commercial activity. \\
\hline 3 & Type & Part of Livestock Machinery Institute — state owned. \\
\hline 4 & Size of Company & 30 people, sales $2.5-5$ million RMB/annum. \\
\hline 5 & Main Business & Village power PV, hybrids, and SHS. \\
\hline 6 & Products & 300-500-W wind generators, integrated wind-diesel battery systems, PV power units, and small SHS. \\
\hline 7 & Existing Licenses & Technology relationship with German company, none with U.S. \\
\hline 8 & Which Geographical Markets Served & Northwestern provinces, Inner Mongolia, and some islands. \\
\hline 9 & Key Market Segments Served & Remote village power, SHS. \\
\hline 10 & $\%$ Share of Segments & $15 \%$ village power, $10 \%$ SHS in general, and $50 \%$ of market in Inner Mongolia. \\
\hline 11 & Main Barriers & Seasonal income of local rural customers and reduced selling price of cashmere. \\
\hline 12 & Current Relationship with U.S. Firm & Distributor for U.S./German module supplier. \\
\hline 13 & Interested in Partnering with U.S. Firm & Yes. \\
\hline 14 & Technology, Product, or Service Sought & Improved electronics. \\
\hline 15 & Preferred Type of Relationship & Technology transfer \\
\hline 16 & Where Can They Find Financing & Limited funds in institute. \\
\hline 17 & Nature of Existing Relationship with U.S. & Distributor. \\
\hline 18 & Which PV Technology is Used & N/A. Do not manufacture PV modules. \\
\hline 19 & Which Part of the Module Process & - \\
\hline 20 & Size of Typical Modules & - \\
\hline 21 & Output in 1997 Watts Peak & - \\
\hline 22 & Reliability Testing Done & - \\
\hline 23 & How Long Have Modules Operated & - \\
\hline 24 & Least Reliable System Component & \\
\hline
\end{tabular}


Company Profiles (Continued)

\begin{tabular}{|c|c|c|}
\hline 1 & Company Name & Ningbo Solar Electric Power Factory_-Ningbo, Zhejiang. \\
\hline 2 & When Established & 1985 \\
\hline 3 & Type & State-owned. \\
\hline 4 & Size of Company & 109 people, 23 million RMB. \\
\hline 5 & Main Business & Modules and some boxed electronics. \\
\hline 6 & Products & Crystalline silicon modules, charge regulators. \\
\hline 7 & Existing Licenses & None. \\
\hline 8 & Which Geographical Markets Served & Northwestern provinces - modest export of small modules to Middle East and Africa. \\
\hline 9 & Key Market Segments Served & Professional communications \& navigation lights $20 \%$, SHS $80 \%, \& 300,000$ solar hats exported to date. \\
\hline 10 & $\%$ Share of Segments & Claimed $40 \%$ share of markets served. \\
\hline 11 & Main Barriers & Purchasing power in the rural unelectrified regions. \\
\hline 12 & Current Relationship with U.S. Firm & None, but has bought Spire equipment. \\
\hline 13 & Interested in Partnering with U.S. Firm & Saw no advantage. \\
\hline 14 & Technology, Product, or Service Sought & None. \\
\hline 15 & Preferred Type of Relationship & $\mathrm{N} / \mathrm{A}$ \\
\hline 16 & Where Can They Find Financing & Local state agency. \\
\hline 17 & Nature of Existing Relationship with U.S. & $\mathrm{N} / \mathrm{A}$ \\
\hline 18 & Which PV Technology is Used & Crystalline silicon—Looking to add polysilicon front-end process to clear bottleneck. \\
\hline 19 & Which Part of the Module Process & Ingots, modules (entire process). \\
\hline 20 & Size of Typical Modules & $\sim 18-22$ watt biggest sellers - need more of their 2-inch cells than is typical to get required voltage. \\
\hline 21 & Output in 1997 Watts Peak & $580 \mathrm{~kW}$ in 1997 - anticipate similar level this year. \\
\hline 22 & Reliability Testing Done & In-house plus significant product in field for $\sim 8$ years $\left(18^{\text {th }}\right.$ Research Institute). \\
\hline 23 & How Long Have Modules Operated & 10 years. \\
\hline 24 & Least Reliable System Component & Small controllers. \\
\hline
\end{tabular}


Company Profiles (Continued)

\begin{tabular}{|c|c|c|}
\hline 1 & Company Name & Qinhuangdao Hua-Mei Photovoltaic Electronic Company, Ltd.-Qinhuangdo. \\
\hline 2 & When Established & 1985 \\
\hline 3 & Type & State-owned joint venture. \\
\hline 4 & Size of Company & 200 employees, 20 million RMB, 20\%-30\% increase per annum. \\
\hline 5 & Main Business & PV modules. \\
\hline 6 & Products & Crystalline modules and electronics. \\
\hline 7 & Existing Licenses & None. \\
\hline 8 & Which Geographical Markets Served & NW provinces in China, no exports to date. \\
\hline 9 & Key Market Segments Served & Professional $80 \%$, SHS markets $20 \%$. \\
\hline 10 & $\%$ Share of Segments & $30 \%$ share professional, $25 \%$ share SHS. \\
\hline 11 & Main Barriers & Cash flow-restricting exports. \\
\hline 12 & Current Relationship with U.S. Firm & None to date; however, several recent visits. \\
\hline 13 & Interested in Partnering with U.S. Firm & Very interested in partnering. \\
\hline 14 & Technology, Product, or Service Sought & Update PV technology, increase capacity, add added-value business. \\
\hline 15 & Preferred Type of Relationship & Joint venture. \\
\hline 16 & Where Can They Find Financing & They would contribute land, machinery. State agencies may match any invested funds. \\
\hline 17 & Nature of Existing Relationship with U.S. & None, but has bought Spire equipment in past. \\
\hline 18 & Which PV Technology is Used & Single crystal. \\
\hline 19 & Which Part of the Module Process & Ingots to modules-entire process. \\
\hline 20 & Size of Typical Modules & $10-40$ watts. \\
\hline 21 & Output in 1997 Watts Peak & $300 \mathrm{~kW}$. \\
\hline 22 & Reliability Testing Done & In-house. \\
\hline 23 & How Long Have Modules Operated & 8 years. \\
\hline 24 & Least Reliable System Component & Electronics. \\
\hline
\end{tabular}


Company Profiles (Continued)

\begin{tabular}{|c|c|c|}
\hline 1 & Company Name & Qinghai Provincial New Energy Research Institute -Xining, Qinghai. \\
\hline 2 & When Established & 1992, first commercial company formed-institute in operation since 1983. \\
\hline 3 & Type & State-owned research institute. \\
\hline 4 & Size of Company & 34 people in commercial company excluding sales outlets; 10 million RMB sales last year (1997). \\
\hline 5 & Main Business & Complete range of systems including wind, solar thermal, and PV. Services include market conditioning. \\
\hline 6 & Products & SHSs, larger communications power units, satellite TV power systems for herdsmen, small wind $(\sim 300 \mathrm{~W})$. \\
\hline 7 & Existing Licenses & None. \\
\hline 8 & Which Geographical Markets Served & Qinghai, Tibet, Gansu, and Sichuan. \\
\hline 9 & Key Market Segments Served & SHSs, small hybrids, and communications. \\
\hline 10 & $\%$ Share of Segments & Before 1995 had $100 \%$ of SHS market in Qinghai. Now said to have $45 \%$ of Qinghai SHS and 30\% in China. \\
\hline 11 & Main Barriers & Lack of credit for sales to rural customers, lack of clear understanding of tech. development in U.S. \& other. \\
\hline 12 & Current Relationship with U.S. Firm & None. \\
\hline 13 & Interested in Partnering with U.S. Firm & Yes. \\
\hline 14 & Technology, Product, or Service Sought & Technology updates and investment to move to stock company. \\
\hline 15 & Preferred Type of Relationship & JV. \\
\hline 16 & Where Can They Find Financing & State owners, including possible low-interest loans. \\
\hline 17 & Nature of Existing Relationship with U.S. & None. \\
\hline 18 & Which PV Technology is Used & N/A. Not a PV module manufacturer. \\
\hline 19 & Which Part of the Module Process & - \\
\hline 20 & Size of Typical Modules & - \\
\hline 21 & Output in 1997 Watts Peak & - \\
\hline 22 & Reliability Testing Done & - \\
\hline 23 & How Long Have Modules Operated & - \\
\hline 24 & Least Reliable System Component & - \\
\hline
\end{tabular}




\section{Company Profiles (Continued)}

\begin{tabular}{|c|c|c|}
\hline 1 & Company Name & Gesang Solar Energy, Ltd.-XXining, Qinghai. \\
\hline 2 & When Established & 1993 \\
\hline 3 & Type & Private, run and owned by Tibetan women. \\
\hline 4 & Size of Company & 22 people, 5 million RMB sales. 6,000 systems (SHS). \\
\hline 5 & Main Business & Assembling SHSs and selling them to Tibetans, both inside and outside of Tibet. \\
\hline 6 & Products & 4-,10-, and 20-W SHSs. \\
\hline 7 & Existing Licenses & None. \\
\hline 8 & Which Geographical Markets Served & Tibet and the provinces bordering Tibet with large Tibetan populations. \\
\hline 9 & Key Market Segments Served & SHS only. \\
\hline 10 & $\%$ Share of Segments & Qinghai SHS 20\%-30\% share, $25 \%$ share in other served regions. \\
\hline 11 & Main Barriers & Technical depth, insufficient funds to expand credit program, and lack of good business planning data. \\
\hline 12 & Current Relationship with U.S. Firm & None. \\
\hline 13 & Interested in Partnering with U.S. Firm & Yes. \\
\hline 14 & Technology, Product, or Service Sought & Greater technical depth and additional funds. \\
\hline 15 & Preferred Type of Relationship & JV (steady growth). \\
\hline 16 & Where Can They Find Financing & Limited own funds. \\
\hline 17 & Nature of Existing Relationship with U.S. & None. \\
\hline 18 & Which PV Technology is Used & N/A. Not a PV module manufacturer. \\
\hline 19 & Which Part of the Module Process & - \\
\hline 20 & Size of Typical Modules & - \\
\hline 21 & Output in 1997 Watts Peak & - \\
\hline 22 & Reliability Testing Done & - \\
\hline 23 & How Long Have Modules Operated & - \\
\hline 24 & Least Reliable System Component & - \\
\hline
\end{tabular}


Company Profiles (Continued)

\begin{tabular}{|c|c|c|}
\hline 1 & Company Name & Qinghai Xining Gesang Solar Energy Company, Ltd.-Xining, Qinghai. \\
\hline 2 & When Established & 1997 \\
\hline 3 & Type & Private stock company, mainly owned by one retired individual. \\
\hline 4 & Size of Company & 19 people, estimated 3 million RMB per annum sales. 100 SHSs per annum rate. \\
\hline 5 & Main Business & SHS assembly and sales. \\
\hline 6 & Products & $10-\mathrm{W}$ and $18-\mathrm{W}$ SHSs, some including lights and radio built into system. \\
\hline 7 & Existing Licenses & None. \\
\hline 8 & Which Geographical Markets Served & Xinjiang, Qinghai, Tibet, Gansu, and Sichuan. \\
\hline 9 & Key Market Segments Served & SHS only. \\
\hline 10 & $\%$ Share of Segments & $\sim 10 \%$ \\
\hline 11 & Main Barriers & Lack of credit sales program. \\
\hline 12 & Current Relationship with U.S. Firm & None. \\
\hline 13 & Interested in Partnering with U.S. Firm & Yes. \\
\hline 14 & Technology, Product, or Service Sought & Need to improve technology. \\
\hline 15 & Preferred Type of Relationship & Balanced joint venture. \\
\hline 16 & Where Can They Find Financing & Original investor and others - modest level. \\
\hline 17 & Nature of Existing Relationship with U.S. & None. \\
\hline 18 & Which PV Technology is Used & N/A. Not module manufacturer. \\
\hline 19 & Which Part of the Module Process & - \\
\hline 20 & Size of Typical Modules & - \\
\hline 21 & Output in 1997 Watts Peak & - \\
\hline 22 & Reliability Testing Done & - \\
\hline 23 & How Long Have Modules Operated & - \\
\hline 24 & Least Reliable System Component & - \\
\hline
\end{tabular}


Company Profiles (Continued)

\begin{tabular}{|c|c|c|}
\hline 1 & Company Name & Qinghai Xining Solar Energy Power Development Center-Xining, Qinghai. \\
\hline 2 & When Established & 1995 \\
\hline 3 & Type & Private stock company, owned by founder/manager. \\
\hline 4 & Size of Company & 42 people, 6 million RMB, 5,000 SHSs per annum. \\
\hline 5 & Main Business & SHSs for rural unelectrified. \\
\hline 6 & Products & 4-, 10-, 20-W SHSs. \\
\hline 7 & Existing Licenses & None. \\
\hline 8 & Which Geographical Markets Served & Qinghai and rest of northwestern provinces, plus Nepal. \\
\hline 9 & Key Market Segments Served & SHSs only. \\
\hline 10 & $\%$ Share of Segments & $10 \%$. \\
\hline 11 & Main Barriers & Sales ability, failure to differentiate product offering, and lack of credit. \\
\hline 12 & Current Relationship with U.S. Firm & None. \\
\hline 13 & Interested in Partnering with U.S. Firm & Yes. \\
\hline 14 & Technology, Product, or Service Sought & Increase technical competence and improve selling reach. \\
\hline 15 & Preferred Type of Relationship & JV. \\
\hline 16 & Where Can They Find Financing & Own funds. \\
\hline 17 & Nature of Existing Relationship with U.S. & None. \\
\hline 18 & Which PV Technology is Used & N/A. Not module manufacturer. \\
\hline 19 & Which Part of the Module Process & - \\
\hline 20 & Size of Typical Modules & - \\
\hline 21 & Output in 1997 Watts Peak & - \\
\hline 22 & Reliability Testing Done & - \\
\hline 23 & How Long Have Modules Operated & - \\
\hline 24 & Least Reliable System Component & - \\
\hline
\end{tabular}




\section{Company Profiles (Continued)}

\begin{tabular}{|c|c|c|}
\hline 1 & Company Name & Shenzhen Nenglian Electronics Company, Ltd.-Shenzhen, Guangdong. \\
\hline 2 & When Established & 1997-However, management has many years of PV systems experience. \\
\hline 3 & Type & Totally private with 3 stockholders. Unique relationship with contract module assembly plant in Hubei. \\
\hline 4 & Size of Company & 8 people in Shenzhen plus partner/contract module assembly plant as needed; sales 11 million RMB 1997. \\
\hline 5 & Main Business & Single-crystal modules both imported and made in China, inverters and controllers and complete systems. \\
\hline 6 & Products & Chinese assembled, $\sim 20-\mathrm{W}$ modules using imported components, locally produced BOS, imported modules. \\
\hline 7 & Existing Licenses & None-Arms-length relationship with U.S. PV component supplier. \\
\hline 8 & Which Geographical Markets Served & Northwestern China, plus Tibet. \\
\hline 9 & Key Market Segments Served & Quality professional systems and small modules to SHS integrators/distributors. \\
\hline 10 & $\%$ Share of Segments & Professional $20 \%$ share. SHS $10 \%$. \\
\hline 11 & Main Barriers & Lack of single agency lead, lack of credit for market, reduced income of herdsmen, small-system quality. \\
\hline 12 & Current Relationship with U.S. Firm & Yes-customer/supplier. \\
\hline 13 & Interested in Partnering with U.S. Firm & Yes. \\
\hline 14 & Technology, Product, or Service Sought & Broaden full system offering and add capital. \\
\hline 15 & Preferred Type of Relationship & Active JV. \\
\hline 16 & Where Can They Find Financing & Current investors plus Shenzhen Special Economic Zone (SEZ). \\
\hline 17 & Nature of Existing Relationship with U.S. & All components \& some complete modules imported from U.S. company. \\
\hline 18 & Which PV Technology is Used & Single-crystal silicon exclusively. \\
\hline 19 & Which Part of the Module Process & Assembly contractor uses imported cells, glass, and encapsulants for small modules. \\
\hline 20 & Size of Typical Modules & 20 watts made in China; $55-\mathrm{W}$ imported finished modules. \\
\hline 21 & Output in 1997 Watts Peak & $\sim 200 \mathrm{~kW} 1997$, possibly lower in current year due to reduced income levels of rural customers. \\
\hline 22 & Reliability Testing Done & Sending modules to $18^{\text {th }}$ Electronics Inst. However, no national standard yet established. \\
\hline 23 & How Long Have Modules Operated & $\sim 100 \mathrm{~kW}$ in field for more than 5 years (from previous ventures but same technology). \\
\hline 24 & Least Reliable System Component & Small-system BOS. \\
\hline
\end{tabular}


Company Profiles (Continued)

\begin{tabular}{|c|c|c|}
\hline 1 & Company Name & Shenzhen-YK Solar Energy Company, Ltd.-Shenzhen, Guangdong. \\
\hline 2 & When Established & 1988 \\
\hline 3 & Type & Originally, JV between Chronar of U.S., Yukong of Korea, Shenzhen regional development, and IMF. \\
\hline 4 & Size of Company & 60 people currently running at reduced level $\sim 30,000 \mathrm{~W}_{\mathrm{p}}$ per month; sales in $1997 \sim 1$ million RMB. \\
\hline 5 & Main Business & Producing and exporting 9-W a-Si modules. \\
\hline 6 & Products & 3' x 1' a-Si modules and some consumer products. Possible addition of calculator-style solar chips process. \\
\hline 7 & Existing Licenses & Lapsed arrangement with initial JV partner Chronar, which subsequently went bankrupt. \\
\hline 8 & Which Geographical Markets Served & Exports only-Southern Africa and Europe. \\
\hline 9 & Key Market Segments Served & Low-cost, consumer-style markets and SHS. \\
\hline 10 & $\%$ Share of Segments & $<5 \%$ share of markets served. \\
\hline 11 & Main Barriers & Reliability question and the focus of Chinese agencies on crystalline silicon. Replacement spare parts. \\
\hline 12 & Current Relationship with U.S. Firm & None at present. \\
\hline 13 & Interested in Partnering with U.S. Firm & Yes. \\
\hline 14 & Technology, Product, or Service Sought & Bringing the process up to a quality standard and assisting in accessing Chinese markets. \\
\hline 15 & Preferred Type of Relationship & JV with investment plus additional technology. \\
\hline 16 & Where Can They Find Financing & Shenzhen Special Economic Zone has very aggressive incentives. \\
\hline 17 & Nature of Existing Relationship with U.S. & N/A. \\
\hline 18 & Which PV Technology is Used & Chronar a-Si single junction. \\
\hline 19 & Which Part of the Module Process & From float glass and gas to finished modules. \\
\hline 20 & Size of Typical Modules & 3 ' x 1'. \\
\hline 21 & Output in 1997 Watts Peak & $50 \mathrm{~kW}$. \\
\hline 22 & Reliability Testing Done & Little to none. \\
\hline 23 & How Long Have Modules Operated & The current module process and encapsulation are not consistent with multiyear life. 2 years claimed. \\
\hline 24 & Least Reliable System Component & Do not supply finished systems. \\
\hline
\end{tabular}


Company Profiles (Continued)

\begin{tabular}{|c|c|c|}
\hline 1 & Company Name & Sinosolar Industry Company, Ltd.--Shenzhen, Guangdong. \\
\hline 2 & When Established & 1993 \\
\hline 3 & Type & $100 \%$ state owned -5 stockholders under Ministry of Electronics Group. \\
\hline 4 & Size of Company & 100 staff in Shenzhen + 80 elsewhere, 60 million RMB sales 1997. \\
\hline 5 & Main Business & Efficient lighting, SHS, submersible pumps. \\
\hline 6 & Products & DC CFLs, range of AC submersible pumps $(250 \mathrm{~W})$. \\
\hline 7 & Existing Licenses & Pump developed with German university involvement-no licence. \\
\hline 8 & Which Geographical Markets Served & Export lights to Europe and elsewhere, SHS to northwestern provinces, pumps still at demo stage. \\
\hline 9 & Key Market Segments Served & SHS rural unelectrified. Efficient lighting. \\
\hline 10 & $\%$ Share of Segments & $<10 \%$ SHS, $\sim<2 \%$ lighting. \\
\hline 11 & Main Barriers & Small size of market in China. \\
\hline 12 & Current Relationship with U.S. Firm & None. \\
\hline 13 & Interested in Partnering with U.S. Firm & None. \\
\hline 14 & Technology, Product, or Service Sought & - \\
\hline 15 & Preferred Type of Relationship & - \\
\hline 16 & Where Can They Find Financing & - \\
\hline 17 & Nature of Existing Relationship with U.S. & - \\
\hline 18 & Which PV Technology is Used & N/A. Do not manufacture PV modules. \\
\hline 19 & Which Part of the Module Process & - \\
\hline 20 & Size of Typical Modules & - \\
\hline 21 & Output in 1997 Watts Peak & - \\
\hline 22 & Reliability Testing Done & - \\
\hline 23 & How Long Have Modules Operated & - \\
\hline 24 & Least Reliable System Component & - \\
\hline
\end{tabular}


Company Profiles (Continued)

\begin{tabular}{|c|c|c|}
\hline 1 & Company Name & Xining New Energy Development Company-Xining, Qinghai. \\
\hline 2 & When Established & 1996 \\
\hline 3 & Type & Private stock company with manager owning majority, plus a few of the workforce. \\
\hline 4 & Size of Company & 35 people, 4-5,000 SHSs per annum, 3 million RMB sales. \\
\hline 5 & Main Business & SHSs including some larger units $(\sim 300 \mathrm{~W})$. \\
\hline 6 & Products & Assemble small SHSs using Chinese modules from range of suppliers. \\
\hline 7 & Existing Licenses & None. \\
\hline 8 & Which Geographical Markets Served & Qinghai, Tibet, Inner Monglolia, Hunan, Gansu, Sichuan, Pakistan, Mongolia, and Nepal. \\
\hline 9 & Key Market Segments Served & SHS. \\
\hline 10 & $\%$ Share of Segments & $25 \%$ share of SHS markets served. \\
\hline 11 & Main Barriers & Technical limits of his workforce. \\
\hline 12 & Current Relationship with U.S. Firm & None. \\
\hline 13 & Interested in Partnering with U.S. Firm & Yes. \\
\hline 14 & Technology, Product, or Service Sought & Technology enhancement plus financing for gradual (step-by-step) growth. \\
\hline 15 & Preferred Type of Relationship & JV partnering. \\
\hline 16 & Where Can They Find Financing & Current investors within limits. \\
\hline 17 & Nature of Existing Relationship with U.S. & None. \\
\hline 18 & Which PV Technology is Used & N/A. Not PV manufacturer. \\
\hline 19 & Which Part of the Module Process & - \\
\hline 20 & Size of Typical Modules & - \\
\hline 21 & Output in 1997 Watts Peak & - \\
\hline 22 & Reliability Testing Done & - \\
\hline 23 & How Long Have Modules Operated & - \\
\hline 24 & Least Reliable System Component & - \\
\hline
\end{tabular}




\section{Company Profiles (Continued)}

\begin{tabular}{|c|c|c|}
\hline 1 & Company Name & Yunnan Semiconductor Devices Factory_-Kunming, Yunnan. \\
\hline 2 & When Established & 1977 \\
\hline 3 & Type & $100 \%$ state ownership under the Yunnan Chamber of Electronics. \\
\hline 4 & Size of Company & 300 employees, $\sim 400$ kW shipped/annum, 20 million RMB sales. \\
\hline 5 & Main Business & Crystalline PVmodules. \\
\hline 6 & Products & Mostly complete systems, some small number of modules without BOS. \\
\hline 7 & Existing Licenses & None. \\
\hline 8 & Which Geographical Markets Served & Western China focusing on Tibet, based on its geographical advantage. \\
\hline 9 & Key Market Segments Served & Professional systems (railways, telecommunications, power systems), SHS. \\
\hline 10 & $\%$ Share of Segments & $40 \%$ professional segment, $20 \%$ SHS. \\
\hline 11 & Main Barriers & Lack of capital to cover technology innovation. \\
\hline 12 & Current Relationship with U.S. Firm & Agreement on controllers. \\
\hline 13 & Interested in Partnering with U.S. Firm & Yes. \\
\hline 14 & Technology, Product, or Service Sought & $\begin{array}{l}\text { Further update PV technology and add polycrystalline silicon processing plus larger-quality inverter } \\
\text { technoloov }\end{array}$ \\
\hline 15 & Preferred Type of Relationship & JV investment. \\
\hline 16 & Where Can They Find Financing & Close relationship with Yunnan agencies. \\
\hline 17 & Nature of Existing Relationship with U.S. & Importing leading to tech transfer. \\
\hline 18 & Which PV Technology is Used & Single-crystal silicon. \\
\hline 19 & Which Part of the Module Process & Complete-pullers to modules. \\
\hline 20 & Size of Typical Modules & 40 watt and $10 \% 20$ watt. \\
\hline 21 & Output in 1997 Watts Peak & $400 \mathrm{~kW}$, expect to grow to $1.5 \mathrm{MW}$ in next few years with addition of polysilicon process. \\
\hline 22 & Reliability Testing Done & In-house and Yunnan Normal University. \\
\hline 23 & How Long Have Modules Operated & 15 years. \\
\hline 24 & Least Reliable System Component & Electronics_-light ballasts. \\
\hline
\end{tabular}


Company Profiles (Concluded)

\begin{tabular}{|c|c|c|}
\hline 1 & Company Name & Zhongxing Electronics Instrument Factory_-Lanzhou, Gansu. \\
\hline 2 & When Established & 1992 PV involvement, sister and parent companies established $10+$ years earlier. \\
\hline 3 & Type & State-owned, part of the Provincial Electronic Industry Corporation. \\
\hline 4 & Size of Company & $1,000 \mathrm{SHS} /$ annum, $>800$ workers in entire factory, sales of energy-saving products 50 million RMB/annum. \\
\hline 5 & Main Business & Energy-saving products. \\
\hline 6 & Products & Water heaters, compact fluorescent tubes, PV SHS, and charge controllers. \\
\hline 7 & Existing Licenses & None. \\
\hline 8 & Which Geographical Markets Served & Gansu, Qinghai, and Sichuan. \\
\hline 9 & Key Market Segments Served & SHSs, small and medium scale $(20,38$, and $100 \mathrm{~W})$, efficient electric water heaters, and CFLs. \\
\hline 10 & $\%$ Share of Segments & $\sim 10 \%$ in SHS. \\
\hline 11 & Main Barriers & High cost of state overhead and lack of own PV production. \\
\hline 12 & Current Relationship with U.S. Firm & None. \\
\hline 13 & Interested in Partnering with U.S. Firm & Yes. \\
\hline 14 & Technology, Product, or Service Sought & PV module technology. \\
\hline 15 & Preferred Type of Relationship & JV. \\
\hline 16 & Where Can They Find Financing & State will contribute and provide $\$ 1-\$ 2 /$ watt subsidy. \\
\hline 17 & Nature of Existing Relationship with U.S. & None. \\
\hline 18 & Which PV Technology is Used & Interested in poly process, but not currently manufacturing. \\
\hline 19 & Which Part of the Module Process & - \\
\hline 20 & Size of Typical Modules & - \\
\hline 21 & Output in 1997 Watts Peak & - \\
\hline 22 & Reliability Testing Done & - \\
\hline 23 & How Long Have Modules Operated & - \\
\hline 24 & Least Reliable System Component & - \\
\hline
\end{tabular}




\section{Itinerary}


Saturday, September 05, 1998

8:00 PM Departed Philadelphia en route Vancouver via Vegas.

Sunday, September 06, 1998

11:30 PM Overnight in Vancouver arriving 2:30 am next morning.

\section{Monday, September 07, 1998}

1:00 PM Departed Vancouver en route Beijing on, Canada Air

3:30 PM Arrived Beijing - by taxi to Traders Hotel

7:00 PM Meeting in Traders Hotel with Li Junfeng \& Zhu Li of CRED.

\section{Tuesday, September 08, 1998}

8:30 AM By car to Cred accompanied by Zhu Li Met other colleagues in office including Wang Zhongying \& Zhou Aimimng.

Received outline itinererary and learned that Zhou will accompany me on the trip to Qinghai and Gansu.

2:30 PM Met in Traders Hotel with Xiuguo Li of the China Academy of Sciences.

8:00 PM Telephone Discussion with Lin Anzhong and agreed to meet as and when 1 get back from travels. I will at that time be able to visit his developmet labs.

10:00 PM Meeting with Wang Spcheng who came to the Traders Hotel after his flight back from travels. Interesting discussions and we agreed that I would give him a telephone call on September 18 to arrange to meet and visit his plant on September 19 (probably pm)

\section{Wednesday, September 09, 1998}

8:30 AM Flight from Beijing to Qinghai - met at Airport in Xining by representatative of local economic council.

2:30 PM Visit to Energy Research Institute of Qinghai Province - briefing by Wu Da -Cheng Chairman and Associate Professor. Solar energy company and institute colocated. The institute is the prime shareholder at $\sim 38 . ? \%$ the rest of the shareholders work in the company.

\section{Thursday, September 10, 1998}

9:00 AM Qinghai Xining New Energy Develpment

Co. Zhao Su -( Ex School Teacher).

11:00 AM Qinghai Xining Solar Energy Power Development Center-Ma Bo. Graduate Automation engineer concerned about product differentiation and market distribution development.

2:00 PM Qinghai Xining Gesang solar -energy Ltd. Co. - Zhuo Ma - Tibetan (female) fniınter
Thursday, September 10, 1998 (Continued)

and credit schemes - finger print signatures - seasonal sales profile. Look at Gender Energy opportunities. -visited their shop in Xining that sells Tibetan medical herbs and dried beef as well as other Tibetan products. (They, husband and wife entertained Joe and I plus Ding Sinian to Tibetan dinner that evening. Concerns expressed about the lack of a Solar Industries Association- as a result they are all competing largely on price.

4:00 PM Xining Dawa Solar Energy Co. - Ding Sinian - young man - larger systems plus boom box product and ideas about separators for butter for the herdsmen. Very detailed questions about the reliability of thin film photovoltaics. The world bank program excludes thin film. a-Si. Explained that a-Si was the answer but reliable a-Si. The small modules area is the natural territory of thin film PV where the cost of producing low wattage and sufficient voltage is lowest

\section{Friday, September 11, 1998}

10:00 AM Visit to solar shops in two of the main streets in Xining. Requested Provincial statistics from the local economic development unit.

\section{Saturday, September 12, 1998}

8:00 AM Depart from Xining via train for Lanzhou in Gansu Province

2:30 PM Meeting with Gansu SPC - SETC

\section{Sunday, September 13, 1998}

9:00 AM Visit to Chongxing Electronics Factory

2:00 PM Gansu PV Company Ltd.

\section{Monday, September 14, 1998}

9:00 AM Visit with Gansu New Energy Research Institute - Gansu Academy of Sciences

4:30 PM Return to Beijing via air.

\section{Tuesday, September 15, 1998}

8:30 AM Brief meeting with John Buckley of UK DTI who was visiting Beijing to organize the UK renewable Energy meeting which was to start the next day in the China World conference center.

9:00 AM Visit to Beijing Solar Energy Research Center in the company of Dr. Jia Xinan of Thermomax.

2:00 PM Visit to Beijing New Building Materials Co. Ltd.

Wednesday, September 16, 1998

9:00 AM Start of three day DOE/MOA workshop at the Sino/European center for 
Wednesday, September 16, 1998 (Continu

Thursday, September 17, 1998

9:00 AM DOE/MOA workshop - Day 2.

Friday, September 18, 1998

2:00 PM Close of DOE/MOA workshop.

3:00 PM Visit to Lin An Zhong Institute for non ferrous metals in Beijing

Saturday, September 19, 1998

8:30 AM Meeting with Dick Blieden United Solar Systems Corp.

3:00 PM Discussions with Wang Sechung of Beijing Jike Energy New Technology Development Co.

Sunday, September 20, 1998

9:00 AM Administartion \& R\&R

Monday, September 21, 1998

8:00 AM Depart Beijing Hotel en route airport.

10:00 AM Flight to Hangzhou visit with Solar PV center in Hangzhou

2:00 PM Visit with China PV Development Center

7:30 PM Overnight Hangzhou

Tuesday, September 22, 1998

8:00 AM Depart for Ningbo via road

11:00 AM Visit with Ningbo Solar Electric Power factory.

9:30 PM Depart by delayed flight from Ningbo en route Shenzhen.

11:30 PM Overnight Shenzhen

Wednesday, September 23, 1998

9:00 AM Meeting with Shenzhen -YK Solar Energy Co. Ltd.

2:30 PM Visit with Shenzhen Nenglian Elecronic Co. Ltd.

9:00 PM Overnight Shenzhen

Thursday, September 24, 1998

9:30 AM Visit with Sinosolar Industry Co. Ltd.

2:30 PM Visit with Shenzhen Municipal Scence and Technology Bureau Dept. of International Cooperation

8:00 PM Overnight Shenzhen

Friday, September 25, 1998

9:00 AM Depart via train to Foshan

2:00 PM Visit with H.K. Co. Scheme Enterprises Holdings Ltd.

9:00 PM Overnight Foshan
Saturday, September 26, 1998

9:30 AM Tour of historic center of Foshan and display of ceramic arts.

2:30 PM Flight to Kunming from Guangdong

5:30 PM Discussions with Yunnan

Semiconductor factory

Sunday, September 27, 1998

9:00 AM Visit to Yunnan Semiconductor Device Factory

Monday, September 28, 1998

8:30 AM Meeting with Yunnan Normal University Solar Energy Research Institute.

12:00 PM Depart Kiunming en route Beijing

3:00 PM Arrive Beijing domestic airport

Tuesday, September 29, 1998

8:30 AM Depart Beijing via train en route Qinhuangdao with Lin An Zhong.

1:00 PM Visit Qinhuangdao Haumei Photoelectronic device Company.

Wednesday, September 30, 1998

9:00 AM Visit with Qihuangdao Alpa Solar Energy Power Co. Ltd.

3:00 PM Depart Qinhuangdao via train en route to Beijing.

10:00 PM Arrive Beijing.

Thursday, October 01, 1998

9:00 AM China National Holiday.

Friday, October 02, 1998

9:00 AM Progress visit report given that China business is on holiday.

Saturday, October 03, 1998

9:00 AM Progress visit report.

\section{Sunday, October 04, 1998}

9:00 AM Progress visit report.

5.30 PM Discussions with Anil Cabraal of the World Bank re: GEF China program. Agreed to discuss in detail in Washington after my trip is completed. Questions asked about distribution notices regarding the China GEF opportunity for international PV firms.

\section{Monday, October 05, 1998}

9:30 AM Change Return Flights to US in order to extend China visit.

7:00 PM Dinner with Madame Deng Keyun, Dai Lin and family. 
Wednesday, October 07, 1998

10:30 AM Visit to Hong Kong.

Thursday, October 08, 1998

2:30 PM Arrive Beijing from Hong Kong.

8:00 PM Night train to Hohhot Inner Mongolia

Friday, October 09, 1998

7:30 AM Arrive Hohhot

9:00 AM New Energy Office of Inner Mongolia ,

11:30 AM Meeting with Prof Ji Binghou Dept of

Physics Inner Mongolia University

2:00 PM Visit to Renewable Energy Center and

Demonstration Site on outskirts of

Hohhot. Meeting with Prof Liu Zhizhang

Inner Mongolia Natural Energy Institute.

\section{Saturday, October 10, 1998}

8:00 AM Travel to remote herding region $250 \mathrm{~km}$ North East of Hohhot to see installed small hybrid systems and the nature of the unelectrified regions in Inner Mongolia.

\section{Sunday, October 11, 1998}

10:00 AM Meeting with Inner Mongolia Wind Power General Company in Hohhot Headquarters Building

2:30 PM Meeting with Huade New Energy Company Hohhot

8:00 PM Night train back to Beijing.

\section{Monday, October 12, 1998}

7:30 AM Arrive Beijing Station.

9:30 AM Meeting with Li Junfeng \& Miao Hong in connection with World Bank GEF project and Brightness Program.

\section{Tuesday, October 13, 1998}

8:30 AM Full day visit to Pinggu County (North West of Beijing) in Company of $\mathrm{Li}$ Jing Ming (MOA) to see progress on 100 Counties program and to learn of the coordinated approach to County Energy/Economy upliftment.

\section{Wednesday, October 14, 1998}

8:00 AM Unable to visit Qingdao due to extreme weather conditions and alternative visits to Bejing officials not possible due to foreign travel or the 2 Solar conferences.

10:00 AM Visited Beijing (R\&R).

Thursday, October 15, 1998

9:30 AM Flight back to Newark via Detroit.

2:30 PM Arrive Newark NJ. 


\section{Business Card Listing}




\section{Business Card Listing}

Alpha Solar Energy Power Company, Ltd.

Zeng Yuan

22 Yanshan Street

Qinhuangdao, Hebei, China

Post Code: 066001

Tel.: (0335) 3071913

Fax: (0338) 3067975

Beijing General Research Institute for Non-Ferrous Metals

An-Zhong Lin, Ph.D., Group Leader

No. 2 Xinjiekou Wai Street

Beijing, China

Post Code: 100088

Tel.: 86-10-62014488 (ext. 4129)

Fax: 86-10-62046618

E-mail: linkang@public.east.cn.net

Beijing New Building Materials Company, Ltd.

William Xiao, Associate Chief Engineer/Senior Engineer

Dewai Xisanqi

Beijing, China

Post Code: 100085

Tel.: 86-10-62913831 (ext. 2271)

Fax: 86-10-62912658

Liang Chongbiao, Ph.D., Senior Engineer

Xisanqi Deshengmenwai

Haidian District, Beijing, China

Post Code: 100085

Tel.: 86-10-82913831-627 82915824

Fax: 86-10-82912658

Beinei Group Corporation-Diesel Engine Factory

Jin Pinli, Director

31 Guangqu Road

Chao Yang District, Beijing, China

Post Code: 100022

Tel.: 67751651

Fax: 67751683

Zhang Shuncheng, Deputy Director/Chief Engineer

31 Guangqu Road

Chao Yang District, Beijing, China

Post Code: 100022

Tel.: 67751651

Fax: 67751683

Center for Renewable Energy Development 


\section{Dai Lin, Chief International Cooperation Economist}

Zhansimen Road

Shahe, Changping County, Beijing, P.R. China

Post Code: 102206

Tel.: 86-10-69733110, 86-10-69737074

Fax: 86-10-69733110

E-mail: dailin@mail.ied.ac.cn

Hu Runqing, Assistant Professor

Zhansimen Road

Shahe, Changping County, Beijing, P.R. China

Post Code: 102206

Tel.: 86-10-69733110, 86-10-69737074

Fax: 86-10-69733110

E-mail: lijf@public.bta.net.cn

Li Jingjing, Deputy Director/Associate Professor

Zhansimen Road

Shahe, Changping County, Beijing, P.R. China

Post Code: 102206

Tel.: 86-10-69733110, 86-10-69737074

Fax: 86-10-69733110

E-mail: jingjing@public.east.cn.net

\section{Li Junfeng, Director}

Zhansimen Road

Shahe, Changping County, Beijing, P.R. China

Post Code: 102206

Tel.: 86-10-69733110, 86-10-69737074

Fax: 86-10-69733110

E-mail: lijf@public.bta.net.cn

Liu Xiaofeng, International Cooperation Research Fellow

Zhansimen Road

Shahe, Changping County, Beijing, P.R. China

Post Code: 102206

Tel.: 86-10-69733110, 86-10-69737074

Fax: 86-10-69733110

E-mail: lijf@public.bta.net.cn

Shi Jingli, Assistant Professor

Zhansimen Road

Shahe, Changping County

Beijing, P.R. China

Post Code: 102206

Tel.: 86-10-69733110, 86-10-69737074

$68342288(\mathrm{H})$ 
Fax: 86-10-69733110

E-mail: lijf@public.bta.net.cn

Center for Renewable Energy Development (Continued)

Wang Zhongying, Deputy Director/Senior Energy Economist

Zhansimen Road

Shahe, Changping County, Beijing, P.R. China

Post Code: 102206

Tel.: 86-10-69733110, 86-10-69737074

Fax: 86-10-69733110

E-mail: lijf@public.bta.net.cn

\section{Zhang Zhengmin, Chief Scientist}

Zhansimen Road

Shahe, Changping County, Beijing, P.R. China

Post Code: 102206

Tel.: 86-10-69733110, 86-10-69737074

Fax: 86-10-69733110

E-mail: lijf@public.bta.net.cn

\section{Zhou Aiming, Research Fellow}

Zhansimen Road

Shahe, Changping County, Beijing, P.R. China

Post Code: 102206

Tel.: 86-10-69733110, 86-10-69737074

Fax: 86-10-69733110

E-mail: lijf@public.bta.net.cn

\section{Zhu Li, Energy Economist}

Zhansimen Road

Shahe, Changping County, Beijing, P.R. China

Post Code: 102206

Tel.: 86-10-69733110, 86-10-69737074

Fax: 86-10-69733110

E-mail: lijf@public.bta.net.cn

Chinese Academy of Sciences, Institute of Policy and Management

Xiuguo Li, Professor

Room 606, Unit 3, Building 410

Ke Xue Yuan Nan Li

Chaoyang District, Beijing, China

Post Code: 100101

Tel.: +86-10-64875548

Fax: +86-10-64875548

E-mail: lixiuguo@163.net

Chinese Energy Research Society

Deng Keyun, Senior Engineer

Beiluyuan, 4-6-201

Baiwain Zhang, Beijing, P.R. China 
Tel.: 64192611

Fax: 66124948

Chinese National Photovoltaic Technology Development Centre

Chang Jinming, President/Senior Engineer

42 Wener Road

Hangzhou, China

Post Code: 310012

Tel.: 0086-571-8840768 8840766

Fax: 0086-571-8840771

Tang Jun, Project Manager/Engineer

42 Wener Road

Hangzhou, China

Post Code: 310012

Tel.: 86-571-8840766

Fax: 86-571-8840771

Xin Mingyi, Deputy Director

42 Wener Road

Hangzhou, China

Post Code: 310012

Tel.: 86-571-8840789

Fax: 86-571-8823621

Chinese National Photovoltaic Technology Development Centre (Kaifeng Solar Cell Factory)

Du Jian Guo, Business Director

No. 45 Xinhua Dong Street

Kaifeng, Henan, China

Post Code: 475000

Tel.: 0378-5957722

Chinese Solar Energy Society

Ji Binghou, Standing Director/Professor, Inner Mongolia University

Hohhot, China

Post Code: 010021

Tel.: (0471) 454433-625

Fax: (0471) 451761

Dawa Solar Energy Company, Ltd. of Xining Qinghai

Ding Si Nian, Manager

No. 1 Shangbin River Street

Xining, Qinghai, China

Post Code: 810000

Tel.: 0971-8213315

Fax: 0971-8213315 
Department of Trade and Industry

John Buckley, Trade Promoter

c/o ETSU

Harwell, Didcot

Oxfordshire, OX11 0RA, United Kingdom

Tel.: $+44(0) 1235433791$

Fax: $+44(0) 1235433213$

E-mail: 101331.663@compuserve.com

Energy Department of the Economic Committee of Guangdong Province

Xie Shi Chao, M.S., Section Chief

No. 305 Dongfeng Road C

Guangzhou, China

Post Code: 510031

Tel.: 020-83133262

Fax: 83333805

Gansu Department of Energy-Environmental Protection Provincial Economic \& Trade Commission Shirong Zhao, Director/Engineer

1 Central Square

Lanzhou, China

Post Code: 730030

Tel.: $81621178465941-25021$

Gansu GNERI Natural Energy Research Institute

Qi Guoqing, Senior Engineer

177 S. Dingxi Road

Lanzhou, Gansu, China

Post Code: 730000

Tel. \& Fax: 86-931-8616243

E-mail: gneri@son.20.gsinfo.sti.ac.ch

Xi Wenhua, Director/Associate Professor

177 S. Dingxi Road

Lanzhou, Gansu, China

Post Code: 730000

Tel.: 86-0931 8611444

Fax: 86-0931 8616243

E-mail: gneri@sun20.gsinfo.sti.ac.ch or gneri@L2.gs.cinfo.net

Zhang Danping, Deputy Director/Engineer

177 S. Dingxi Road

Lanzhou, Gansu, China

Post Code: 730000

Tel.: 86-931-8616615 (ext. 2061)

Fax: 86-931-8616243

E-mail: gneri@sun20.gsinfo.sti.ac.ch 
Gansu PV Company, Ltd.

Wang Yu, CEO/Senior Engineer

12 Nanchang Road

Lanzhou, China

Post Code: 730000

Tel.: 0931-8842317

General Research Institute for Non-Ferrous Metals

An-Zhong Lin, Ph.D., Group Leader

No. 2 Xin Jie Kou Wai Da Jie

Beijing, China

Post Code: 100088

Tel.: 861-62014488 (ext. 4129)

Fax: 861-62040618

E-mail: linkang@public.east.cn.net

Wu Ruiha, Professor/Higher Senior Engineer

2 Xin Jie Kou Wai Da Jie

Beijing, China

Post Code: 100088

Tel.: 62001806

E-mail: WRHZY@inw.com.cn

Gesang Solar Energy Ltd. Company of Xining (Qinghai)

Shen Mao

No. 12-1 Changjiang Street

Xining, Qinghai, China

Post Code: 8810000

Tel.: 0971-6130963, 8246514

Fax: 0971-8246514

H.K. Company Scheme Enterprises Holdings Ltd.

Foshan Economics Commission (State Organization)

Ou Zhi Xian, Vice-Chief of Section/Engineer

5/F, 8 Pulan-2 Road

Foshan, Guangdong, China

Post Code: 528000

Tel.: 3320181

Fax: 3322379

Foshan Municipality Economy Committee (State Organization)

Liu Shi Kai, Vice Director

No. 8 Pulan-2 Road

Foshan, Guangdong, China

Post Code: 528000

Tel.: (0757) 3328879

Fax: (0757) 3322379 
Foshan Plastics Group Company Ltd. (Private Firm)

Zhang Hong, Senior Interpreter

82 Fenjiang Zhong Road

Foshan, Guangdong, China

Post Code: 528000

Tel.: (0757) 2283570

Fax: (0757) 2282344

E-mail: gzfsyf_e@.public1.guangzhou.gd.cn

Guangdong Province, Economic Committee (Energy Dept.) (State Organization)

Xie Shi Chao, M.S./Section Chief

305 Dongfeng Road C.

Guangzhou, China

Post Code: 510031

Tel.: 020-83133262

Fax: 83333805

Huade New Technology Company of Inner Mongolia

Jianping Qin, General Manager/Senior Engineer

506 Zhaowuda Road

Hohhot, P.R. China

Post Code: 010010

Tel.: 0471-4913805

Fax: 0471- 4951674

E-mail: qjp@public.hh.nm.cn

Yang Shikun

No. 506 Wuda Street

Xincheng Region, Huhehaode, Inner Mongolia, P.R. China

Post Code: 010010

Tel.: $0471-4913805$

Fax: 0471-4968471

E-mail: huadecom@publich.hh.nm.cn

Huanyu Wind PV New Technology Ltd. of Inner Mongolia

Yangbin

Inner Mongolia, P.R. China

Post Code: 013450

Tel.: 0474-6901231

Fax: 0474-6902461

Inner Mongolia Natural Energy Institute

Liu Zhizhang

Hohhot, Inner Mongolia, P.R. China

Post Code: 010062 
Tel.: 6511533

Telex: 6503298

E-mail: Liuzz@mail.impu.edu.cn

Inner Mongolia New Energy Office

Lin Li, Director/Senior Engineer

141 Xin Cheng West Street

Inner Mongolia Science \& Technology Mansion

Hohhot, Inner Mongolia, P.R. China

Post Code: 010010

Tel.: (0471) 6921193

Fax: (0471) 6929306

Pang Shu Qin, Senior Engineer

141 Xin Cheng West Street

Inner Mongolia Science \& Technology Mansion

Hohhot, Inner Mongolia, P.R. China

Post Code: 010010

Tel.: (0471) 6921193

Fax: (0471) 6965929

Inner Mongolia Wind Power General Company

Chen Tong Mo, Adviser/Senior Engineer

218 Xin Lin South Road

Hohhot, Inner Mongolia, P.R. China

Post Code: 010020

Tel.: (0471) 6943461

Fax: (0471) 6942348

Zang Rui, Senior Engineer

218 Xi Lin South Road

Hohhot, Inner Mongolia, P.R. China

Post Code: 010020

Tel.: (0471) 6942348

Fax: (0471) 6924863

Zang Wenzhong, Production \& Technology Dept./Electrical Engineer

218 Xi Lin South Road

Hohhot, Inner Mongolia, P.R. China

Post Code: 010020

Tel.: (0471) 6943722

Fax: (0471) 69248636924863

Jike Energy New Technology Development Company of Beijing

Dong Luying, Assistant General Manager/Senior Engineer

No. 25 Qinghuadonglu

P.O. Box 927

Beijing, China 
Post Code: 100083

Tel.: 86-10-62344485

Fax: 86-10-62347144

Jike Energy New Technology Development Company of Beijing (Continued)

Wang Sicheng

No. 25 Tsinghua Street

Haidian Region, Beijing, China

Post Code: 100083

Tel.: 010-62344485

Fax: 010-62347144

Lanxing Industry and Commerce Company of Gansu

Feng Changjiang

No. 1681 Donggan East Road

Lanzhou, Gansu, China

Post Code: 730020

Tel.: 0931-8497615-180

Fax: 0931-8497530

Lanxing Whole System Assembling Company

Zi Liang Li, Manager/Economist

1681 Dongguandong Road

Lanzhou City, Gansu, China

Post Code: 730020

Tel.: (0931) 8651334

Fax: (0931) 8497530

Lanxing Wireless Electronics Factory (Ministry of Electronics)

\section{Zhong Jiang Peng}

1681 Dongguandong Road

Lanzhou City, Gansu, China

Post Code: 730020

Tel.: 8497615

Fax: 8497530

Lida New Energy Electronic Ltd. of Xinjiang

\section{Liu Juan}

Attached No. 6 of No. 12 Tuanjie Street

Urumqi, Xinjiang, Uygur Autonomous Region, China

Post Code: 830001

Tel.: 0991-2864425

Fax: 0991-2867449

National Engineering Research Centre/Beijing Solar Energy Research Institute (Beijing Sunpu Corp.)

\section{Li Zhongming}

3 Huayuan Road

Haidian District

Beijing, China

Post Code: 100083 
Tel.: 2018821, 2018887-3263

Fax: 861-2012880

New Energy Development Company, Ltd.

\section{Zhao Shu}

No. 26 Yongjun Alley East Town Region

Xining, Qinhai, China

Post Code: 810007

Tel.: 0971-8141965

Fax: 0971-8214416

New Energy Research Institute of Qinghai Province

Wu Da-Cheng, Chairman/Associate Professor

22 Wusi West Street, Xi Ning

Qinghai, China

Post Code: 810008

Tel.: 86-971-6135523 6154763

Fax: 86-971-6135523

Ningbo Solar Electric Power Factory

Fu Zhang Zhou

No. 80, Chanfong Street

Ningbo City, Zhejiang Province, China

Post Code: 315010

Tel.: (0574) 7121586

Fax: (0574) 7121586

\section{Zhou Kai Fu, Director/Engineer}

Xijiao, Qian Feng

Ningbo, Zhe Jiang, China

Post Code: 315010

Tel.: (0574) 7121586

Fax: (0574) 7121586

Pinggu County Energy Resources Office

Gao Shu Qiang, Party Secretary/Director/ Senior Agronomist

No. 6 Xinkai Street

Pinggu, China

Post Code: 101200

Tel.: 6996344

Qinghai New Energy Research Institute

Zhimin Zhang

No. 22 Wu-Shi West Road

Xining City, Qinghai, China

Post Code: 810008

Tel.: (0971) 6154262

Fax: (0971) 6150984

Qinghai Xining Gesang SolarEnerge Company, Ltd.

Zhuo Mou, Manager 
Guo Luo Xinig-based agency (Bus No. 9)

Tel.: 0971-6130963

Fax: 0971-8246514

Qinghuangdao Hua-Mei Photovoltaic Company, Ltd.

\section{Hui Hua Do}

No. 86 Jianguo Road

Qinghuangdao City, Hebei Province, China

Post Code: 066000

Tel.: (0335) 3031234-8044

Fax: (0335) 3035394

\section{Li Shu Gui, Senior Engineer}

No. 86 Jianguo Road

Qinhuangdao City, Hebei Province, China

Post Code: 066000

Tel.: (0335) 3031234

Fax: (0335) 3035394

Yen Fen Chang

No. 86 Jianguo Road

Qinghuangdao City, Hebei Province, China

Post Code: 066000

Tel.: (0335) 3035394

Fax: (0335) 3035394

Zhong Yongkun, Vice General Manager/Senior Accountant

No. 86 Jianguo Road

Qinhuangdao City, Hebei Province, China

Post Code: 066000

Tel.: (0335) 3031234

Fax: (0335) 3035394

Qinghuangdao Mechanical Electronic Industry Bureau

Xin Hua Chang, Chief Engineer

No. 27 Hongqi Road

Qinhuangdao, China

Post Code: 066000

Tel.: (0335) 3020934

Shanshui City, Lowping Township, People's Government

Yun Chi Zhi

Lowping Township

Shanshui City, Guandong Province, China

Post Code: 528137

Tel.: (0757) 7388566 
Shenzen Economy Development Bureau

Jiang Hai Yong

Room 425 4/F, The Second Building of Shenzen

Municipal Government

No. 8 Shang Bu Road

Shenzen, P.R. China

Post Code: 518006

Tel.: (0755) 2243851

Fax: (0755) 2240699

\section{Xu Jian, Doctor of Engineering}

Room 429 4/F, The Second Building of Shenzen

Municipal Government

No. 8 Shang Bu Road

Shenzen, P.R. China

Post Code: 518006

Tel.: (0755) 2223211-4418

Fax: (0755) 2240699

Shenzen-YK Solar Energy Company, Ltd.

Chen Can, District Sales Manager

Room 2001, 20/F, Yuehai Jinwei Building

No. 27 Jiabin Road

Shenzen, China

Post Code: -

Tel.: 86-755-5591013

Fax: 86-755-5591013

Chen Wu Kui, Chairman/General Manager

5\&6/F, 21 Street, Block Shuibei

First Road, Shuibei Industrial Area

Shenzen, China

Post Code: -

Tel.: (0755) 5501466

Fax: (0755) 5530984

Hu Qian, Vice General Manager

5\&6/F, 21 Street, Block Shuibei

First Road, Shuibei Industrial Area

Shenzen, China

Post Code: -

Tel.: (0755) 5501502

Fax: (0755) 5530984

Lin Xiao Feng, Marketing Department

5\&6/F, 21 Street, Block Shuibei

First Road, Shuibei Industrial Area

Shenzen, China 
Post Code: -

Tel.: (0755) 55069055501466

Fax: (0755) 5530984

Yang Wen Biao, Manager-Sales Department

Room 2001, 20/F, Yuehai Jinwei Building

No. 27 Jiabin Road

Shenzen, China

Post Code: -

Tel.: 86-755-5591013

Fax: 86-755-5591013

\section{Zeng Zu Qin, Director, General Manager/Senior Engineer}

Room 2001, 20/F, Yuehai Jinwei Building

No. 27 Jiabin Road

Shenzen, China

Post Code: -

Tel.: 86-755-5591013

Fax: 86-755-5591013

Shenzen Municipal Science \& Technology Bureau

Jeff J.P. Zhu

18, Shennan Road Central

Shenzen, P.R. China

Post Code: 518031

Tel.: 86-755-3205699

Fax: 86-755-3320184

Shenzen Science \& Technology Commission

\section{Li Zhongxiang}

Room 406

Shangbu Road

Shenzen, China

Sinosolar Industry Company, Ltd.

Ke Ping, Vice General Manager

West 6/F, 201 Building Chegongmiao Industrial Area

Shennan Road

Shenzen, China

Post Code: 518040

Tel.: 3303912

Fax: (0755) 3301865

E-mail: szzrl@public.52ptt.net.cn

Xu Shi Bin, Vice G. Engineer

6/F Block

201 Terra Industry Company, Ltd.

Shennan Road

Shenzen, China

Post Code: 518040 
Tel.: 3301166-8118

Fax: 3301865

Sino-U.S. Solar PV Joint Venture of Gansu (Anhua PV)

\section{Wang Anhua}

No. 12 Nanchang Street

Lanzhou, China

Post Code: 730000

Tel.: 0931-8842317

Fax: 0931-8616405

E-mail: wanhua@public.lz.gs.cn

Solar Electric Power Ltd. of Qinghai

Wu Dacheng

No. 22 Wusi West Road Xining

Qinghai, China

Post Code: 810008

Tel.: 0971-6154741, 6154763

Fax: 0971-6135532

Solar Electronic Engineering Company of Urumqi

\section{Yu Guoguang}

No. 2 Shengli Street

Urumqi, Xingjiang, China

Post Code: 830001

Tel.: 0991-2866602, 2861879

Fax: 0991-2881582

Solar Energy Science and Technology Development Company of Tibet

\section{Wang Guohua}

No. 40 Beijing South Street

Urumqi, Xinjiang, Uygur Autonomous Region, China

Tel.: 0991-3835905, 3835922

Fax: 0991-3835920

Solar Energy Society of Qinghai Province

Chi Yan Ho

Building W3

Qinghai Provincial Government, China

Post Code: 810000

Tel.: (0971) 8244844

Solar Power Development Center of Xining, Qinghai

Ma Bo

No. 4 Microwave Alley

Xining, Qinghai, China

Post Code: 810001

Tel.: 0971-6139601, 1399715308 
State Economic and Trade Commission

Liu Hongpeng

27 Xuanwumen

Xidajie, Beijing, P.R. China

Post Code: 100053

Tel.: 63193469

Fax: 63193460

E-mail: liuhp@public.bta.net.cn

Thermomax

\section{Dr. Jia Xinan}

Singapore Office

16 Cactus Road, Singapore 809585

Tel.: (65) 4831031

Fax: (65) 4835343

Headquarters: Balloo Crescent

Bangor BT19 2UP

United Kingdom

Tel.: (1247) 270411

Fax: (1247) 270572

Tianpu Solar Science and Technology Ltd. of Qinghai

Yang Zhigang

No. 3 Hutai East Alley

Xining, Qinghai, China

Post Code: 810008

Tel.: 1399717834

Fax: 0971-8215430

United Nations Development Programme

Xiadong Wang, Ph.D./GEF Technical Specialist for Climate Change

2499 Kapiolani Boulevard, Apt. 2900

Honolulu, Hawaii 96826

Tel./Fax: (808) 946-3742

E-mail: xiadong.wang@undp.org

Urumqi TaiKe High and New Technological Company, Ltd.

Yu Guo Guang, General Manager/Vice Chairman of the Board

Street No. 72

Xinjiang, China

Post Code: 830011

Tel.: 0086-0991-286602

Fax: 0086-0991-2862274

Wind Energy Company of Xinjiang

Yu Wuming

Tel.: 0991-5852435, 3714095

Fax: 0991-5816456

E-mail: xjwind@public.wi.xj.cn

Xinjiang New Energy Research Institute 


\section{Wang Guo Hua, Director/Research Professor}

No. 40, Beijing South Road

Xinjiang, P.R. China

Post Code: 830011

Tel.: (0991) 3835905

Fax: (0991) 3835920

Yunnan Normal University-Solar Energy Research Institute

Xie Jian, Vice-Director, Associate Professor

Kunming, Yunnan Province, P.R. China

Post Code: 650092

Tel.: 86-871-5322930 (ext. 6229, 6081)

Yunnan Provincial Economic \& Trade Company of China Resources Utilize Department

Xiao Guo Bao, Director

Dong Feng Eastan Road

Kunming, China

Post Code: 650041

Tel.: 0871-3327129

Fax: 0871-3327129

Yunnan Semiconductor Devices Factory

Wu Cong

Jian She Lu 24

Kunming, P.R. China

Post Code: 650033

Tel.: +86 (871) 5362240

Fax: +86 (871) 5337279

E-mail: yusemico@elephant.istiy.yn.cn

\section{Zhu Huimin, Vice Director}

No. 24 Jian She Road

Kunming, China

Post Code: 650033

Tel.: (0871) 5321431

Fax: (0871) 5337279

\section{Zhu Xiaomin, Director}

Jian She Lu 24

Kunming, P.R. China

Post Code: 650033

Tel.: +86 (871) 5337279

Fax: +86 (871) 5337279

E-mail: yusemico@elephant.istiy.yn.cn 
Zhongxing Electronic Instruments Factory Ning Zuo Wei, Head of Factory/Engineer

No. 150 Majiazhuang, Anning District

Lanzhou City, China

Post Code: 730070

Tel.: (0931) 7666051/0931-7675754

Fax: 0931-7675735 


\section{Visit Report-Detailed Company/Organization Profiles}

Please note: The information presented in the following section is subject to possible errors due to translation errors, difficulties in communication, and other factors. 


\section{Alpha Solar Energy Power Company, Ltd. Qinhuangdao, Hebei. 9/30/98}

Alpha Solar is a joint venture between Alpha Solar of the United States, a Hong Kong R\&D concern, and the provincial electronics industry. After initial discussions in 1990, concentrator product testing began in 1994-1995. The first 15-kW system was installed in Tibet in 1998. (The special demonstration selling price was $100 \mathrm{RMB}$ per $\mathrm{W}_{\mathrm{p}}$.) $\$ 2.4$ million was contributed by the Chinese parties and $\$ 1.6$ million by the U.S. firm. (The Hong Kong R\&D firm contributed only $\$ 200 \mathrm{~K}$.) The special-purpose cell/substrate attachment equipment was supplied from the United States; the large sheet presses required to stamp out the aluminum troughs for the $150-\mathrm{W}$ modules were of Chinese origin.

The concentrator solar cells, the Fresnel lens sheets, and a special double-sided tape are all imported from the United States; the remainder of the direct materials are from China. The cells cost $\$ 4 /$ unit, which ultimately provides an output of 6.5 watts under 400 times concentration. The cells, Fresnel lens, and tape contribute approximately $10 \%$ of the finished system selling price of $130 \mathrm{RMB} / \mathrm{watt}$. The finished modules, which provide approximately 150 watts, appear to be about the same area as two 55$\mathrm{W}$, flat-plate modules placed end to end. With scanning, the concentrator modules, which are sold at the same peak-watt price as flat-plate modules, provide approximately $30 \%$ more output than a scanned flat-plate array. A demonstration $1.5-\mathrm{kW}$ scanned concentrator array was observed within the grounds of the Qinhuangdao plant.

\section{Beijing General Research Institute for Non-Ferrous Metals Beijing. 9/18/98}

Within this very large complex that also houses a considerable semiconductor fabrication operation, the PV activity is relatively modest, with a staff of 15 people. The budget, approximately $\$ 200,000$ per annum, now has to be $50 \%$ funded from sales of product. (The remainder comes from government sources.) The small unit assembles crystalline modules, which are then sold to the small distributors (who in turn assemble and sell SHSs). The selling price of the modules is approximately 40-50 RMB per watt. The most popular modules are the 10- and 11-watt units. Current sales are only $20 \mathrm{~kW}$ per annum; this level of market activity is not sufficient to destroy the institute's technical relationships with other established PV manufacturers in China. Their PV research began in 1980 and their commercial activity has been under way since 1985. Although the institute's PV manufacturing line may be of modest scale, they understand what it takes to make a quality PV module. The techniques employed and the equipment in evidence, from pullers to ID saws to the laminator, were typically of U.S. origin; however, the institute used a considerable amount of manual labor, as was to be expected in a country such as China. The modules made by the institute have undergone limited environmental testing at various Chinese facilities; to date, however, no international test certification has been obtained.

The institute's group leader (An-Zhong Lin) is a respected PV expert who acted as a guide and interpreter for the visit to the two PV companies in Qinhuangdao. In addition to the work on crystalline silicon, the institute also develops thin-film photovoltaics, including amorphous silicon (a-Si). The small-scale a-Si line has been used to develop processing techniques suitable for solar-calculator PV cells. This processing method for solar-calculator chips was apparently supplied to the Shenzhen-based a-Si business. 


\section{Beijing New Building Materials Company, Ltd. Beijing. 9/15/98}

This diverse building material company has an interest in entering the PV arena. They currently have many factories throughout China, in which are produced everything from steel framing for buildings to wall finishing to roof materials to complete buildings. Within their factory grounds at Beijing headquarters, they have a very modern solar home with a $7.5-\mathrm{kW}$, grid-connected solar PV roof. The roof tiles use AstroPower, Inc., crystalline cells; the tiles were supplied from Europe, as were the various control units for the house. The overall finish of the house, including the solar roof, looked very professional, thus reflecting this entrepreneurial company's considerable resources and technical expertise. At the time of the visit, there were ongoing discussions with an existing international PV supplier that might lead to a joint venture. As with most other discussions in China, there was a general intent to take any venture that developed a step at a time; therefore, it is unlikely that one would see this firm leading in the Chinese PV market within the next few years. However, they would apparently be able to bring considerable resources and buildings expertise to bear on the PV integration market. Their focus is somewhat broader than simply any building-related markets; they are planning to serve the remote SHS markets as well.

\section{Beijing Solar Energy Research Center Beijing. 9/15/98}

After 18 years of R\&D, Beijing Solar Energy is most likely the largest solar thermal manufacturer in China. Established in 1979, the center now has a staff of 250 and carries out development activities in solar thermal and PV power generation. Their commercial arm, Sunpo, was established in 1988 to promote the commercialization of Beijing Solar's products. Sunpo's sales have reached 200 million RMB per annum, mostly from the sale of solar thermal energy conversion equipment. In 1992, under the auspices of the Chinese Academy of Sciences, the State Economic and Trade Commission established the National Engineering Center with the Solar Energy Research Center. Since that time, they have developed solar cells based on the Czochralski process and thin silicon. Currently, their highest efficiency is $19.70 \%$, and their buried-contact $5 \times 5 \mathrm{~cm}$ cells have reached $18.6 \%$ efficiency. Their poly thin film has reached $12.5 \%$ efficiency.

In addition to R\&D on solar PV, they have developed a pilot production line that currently focuses on making cells; however, they do have a plan to start manufacturing modules in the next few years. In the solar thermal area, they have been producing evacuated heat pipes for the last two years as part of a joint venture. Their tube capacity is approximately 500,000 per annum; they are actually producing about 100,000 tubes per annum.

There were many solar thermal units on display around the grounds of the center as well as in the company showroom. Their line of efficient stoves was also on display.

\section{Beinei Group Corporation-Diesel Engine Factory Beijing. 10/6/98}

Given that diesel generators - which need service and maintenance support — are generally also used in remote unelectrified areas, this visit to one of the major diesel manufacturers in China was arranged to get some firsthand understanding of the solutions adopted by diesel suppliers. This factory manufactures two basic types of diesel motor: air cooled and water cooled. Typically, they make about 5,000 units per annum of the 912 type (air cooled) and approximately 8,000 units of the 4115 type (water cooled). Some of the motor technology was originally introduced from Germany (KHD) in 1981; 
however, the motors are now made entirely in China. Most of the components (including fairly large engine block castings) are actually made at the factory site in Beijing. Some smaller aluminum castings are purchased from a separate supplier in China, because the technology is not compatible with the corporation's current processes. The small motors used for electricity generation are typically $85 \mathrm{~kW}$ and the biggest units that they make at this site are $140 \mathrm{~kW}$.

The air-cooled units are more suitable for the colder regions where the water might freeze or for the areas where the water quality is bad. To date they have supplied 300,000 water-cooled units and 70,000 air-cooled units in China, with the typical price of the air-cooled units being 34,000 RMB and that of the water-cooled units being 15,000 RMB. As was the case with many other suppliers in China, this company was not having a typical year; sales were down due to the slump in the economy, and they expected to sell only 2,000 air-cooled motors and 5,000 water-cooled units.

The factory has a workforce of 708 people, and the Beinei Group as a whole has about 9,000 employees. The factory sales force totals 17 people; they sell to distributors and generator manufacturers throughout China. Although they do not sell to end users, they do provide a network of maintenance facilities throughout China to fulfill the guarantees and provide after-sales maintenance (as required). The repair/maintenance work on motors over one year old is carried out on a cost-ofmaterials basis only; travel and labor costs are borne by the company. Beinei Group has nine regional service centers throughout China with a total service staff of 41 people. Not surprisingly, given the bulk of the motors, these service engineers go to remote locations to service and repair machines. The group budget for the overall cost of supplying this service network and funding the guarantee and after-sales services is said to be only $1 \%$ of the total turnover. Sales in this current year are expected to reach 200 million RMB (\$25 million U.S.).

Beinei claims to be the largest supplier of this type/size of motor in China. The corporation estimates that around $20 \%$ of its motors are used in generators to provide electricity. The company estimates that approximately 200 motors $(40 \mathrm{~kW})$ per annum are sold for water-pumping applications.

In addition to providing their detailed operation and maintenance manual for the air-cooled motors, the Beinei Group also supplied a comprehensive list of their main customers throughout China.

\section{Center for Renewable Energy Development Energy Research Institute State Planning Commission. Beijing 10/12/98}

This meeting was arranged to get a clearer understanding of the GEF/World Bank and UNDP renewables activities in China, as well as to gain some insight into the progress achieved by the Brightness Program. The GEF program has two parts: a 190-MW wind component for grid-connected wind farms, and a 10-MW PV component for rural homes, schools, hospitals, and administrative facilities. The total GEF/World Bank budget for this program is $\$ 390$ million, while the associated GEF/UNDP project has a budget of $\$ 26$ million for capacity building.

The wind portion of the program will involve installations at five sites in four provinces, with $100 \mathrm{MW}$ slated for Inner Mongolia. The 300-kW PPAs are said to be ready, with power prices of 0.7-0.62 RMB (based on wind speeds). The wind turbines are financed principally by loans at $5 \%-6 \%$ for $20+5$ years. (The five years represents the grace period.) Another contract requirement is that there be more than a $20 \%$ equity component; the rest can be loan. The wind turbines must be of an internationally recognized standard of performance, and no less than $15 \%$ of the purchases will have to be made locally. The overall plan aims to reduce the cost of wind-based electricity and to build up the Chinese 
capacity to manufacture low-cost wind turbines. The program is currently at the preparation stage. The time frame for the approval of the program was March/June 1999.

The goal of the PV program is to have $10 \mathrm{MW}$ installed over a five-year period. The current focus is on qualifying the various distributors/integrators by requiring them to have their PV components and balance of systems (BOS) evaluated. Subsequently, provided qualified (listed) components are used and PV systems are supplied to the target areas, companies will be able to receive a subsidy per system against proof of sale (invoice). A small fraction of the subsidy will be retained up to $\$ 1.50 / \mathrm{W}$ until the end of the program to ensure that the suppliers take care of their customers and provide adequate service and maintenance.

There are currently 17 companies on the list of participating firms from the northwestern provinces, as well as Inner Mongolia and Beijing. The 17 firms have been chosen from the list of 25 original applicants based on certain criteria (i.e., whether or not they are legal entities having at least three years of PV business experience and suitable financial statements). Given the nature of many of the 17 companies and the typical quality of the small PV systems that they currently supply, the task of qualifying all of the participants will be extremely challenging. Given also that some of the companies do not currently need to issue formal invoices or pay taxes it is difficult to imagine that all would opt to change their current (presumably profitable) practices, procure qualified components (rather than making their own less-reliable BOS), and risk paying taxes to gain $\sim \$ 1.50 / \mathrm{W}$ in system subsidy. Based on a typical small-system selling price of $\$ 10 / \mathrm{W}$, of which the purchased modules represent more than $50 \%$ of the selling price, it would appear that one would have an uphill struggle to "convert" the many small distributors/integrators. In the meantime, the companies are being assisted in preparing business plans; they have all prepared their second-draft plans.

Currently, single-crystal and polycrystalline silicon are the only module technologies accepted under this program. Assisting some of the myriad of distributors who routinely produce their own questionable system electronics to make qualified controllers or dc light circuits, and continuing to make qualified circuits in remote regions despite their modest resources and technical understanding, represents a considerable challenge. Auditing the remotely supplied SHSs, which are frequently supplied to remote farmers and nomadic herdsmen, is logistically very demanding. In the herding areas covered by this program, remote might be $50 \mathrm{~km}$ from the nearest small village (let alone a significant administrative center). The target provinces and autonomous regions for this PV program are Inner Mongolia, Gansu, Qinghai, Xinjiang, and Sichuan, plus Tibet.

The flow of subsidy to the systems suppliers will be triggered by a copy of the sales invoice, which must include the selling date and the customer's name and address (which are then forwarded to the Project Management Office [PMO]). The invoices will be submitted every three months; once they have been reviewed by the PMO they will be forwarded, if acceptable, to the Ministry of Finance (MOF), which will be charged with paying the subsidy or at least $95 \%$ against invoice. The remaining $5 \%$ will be retained until the end of the project ( $\sim$ five years) to encourage good customer service. All customers will be supplied with the contact details of the local PMO or other organization to whom they will be able to submit any complaints regarding the quality of the product or service. At the end of the five years, assuming that there have been no significant problems, the supplier will get the 5\% with suitable interest. One can imagine that if the payment process via the PMO and the MOF for the initial subsidy takes a significant time ( $\sim$ six months), then it would begin to resemble the cash flow equivalent of providing customer credit, albeit for a modest percentage of the product value and for (hopefully) no risk of bad debts. At the Center for Renewable Energy Development, Ms. Miao Hong currently occupies the PMO roll. 
The Brightness Program was launched in 1996 by the State Development and Planning Commission. The renewables objective was to supply lighting power to the remote unelectrified areas. The technologies involved are solar PV, small wind, hydro, and biomass cogeneration. Despite the bold outline, there is said to be no real dedicated money; rather, it appears that existing or new programs will be coopted into the Brightness basket. The target is to supply 20 million people with small renewable systems by the year 2010. (Poverty alleviation money and MOA money will be used to help reach the 2010 target.) The Ministry of Power's target is to electrify $95 \%$ of all households by the year 2000 using grid extension and small hydro. Currently, about $90 \%$ of the households are electrified.

Another PV program currently at the planning stage is the Dutch/Shell project for the Xinjiang autonomous region. The letter of intent was apparently signed in March 1998 for the eventual supply of $60,00025-50$-W systems in the region of Xinjiang. The households might be required to pay $1,400-$ 1,700 RMB per 25-W system; the Dutch government would provide money for $60 \%$ of total equipment costs. The remaining monies would be found locally. Throughout the trip there was considerable concern expressed by indigenous module and systems providers about the possibly high level of subsidy that might be provided to the end customers on this project. High subsidies are considered to be damaging to the real commercial PV markets in China as a whole, while not necessarily leading to a sustainable situation in the focus region of the specific project.

\section{China Photovoltaic Technology Development Center Hangzhou, Zhejiang. 9/27/98}

Established in 1983, the China PV Technology Center operates as a nonprofit facility and a coordinating body for many of China's universities and institutes that take part in the various PV development tasks within the current five-year national development plan (the 8th). In 1990, the center helped develop (and subsequently coordinate) the plan; it later assisted with some PV projects within the plan, such as increasing efficiency levels and conducting research on polycrystalline silicon films. There is also a plan to introduce multisilicon technology to Chinese industry from abroad. Apparently, one major U.S. polysilicon manufacturer was approached but was said to be uninterested in the opportunity/challenge.

The effort to introduce multicrystalline silicon technology is part of the aforementioned national plan; the center, meanwhile, is completing plans to import a production facility in the next year. The step-bystep approach will start with a casting and wafering facility of about $1 \mathrm{MW}$ per annum capacity. The suggested ingot capacity was estimated at $100-150 \mathrm{~kg}$. In addition, a wire saw is on the agenda. The center estimated total indigenous Chinese PV capacity at $5 \mathrm{MW}$, with approximately $2 \mathrm{MW}$ currently being produced each year. The major focus of all the activity, however, is on environmental protection, which will be achieved by reductions in conventional energy consumption.

The center is supported by the Ministry of Science and Technology (MOST), as well as the central and provincial governments. In addition, the center expects to receive support from the international community through collaborative programs or information exchanges. The center may establish a separate company and would be interested in joint ventures with foreign entities. Apparently, there is considerable flexibility in the possible structuring of such arrangements.

The locally based (within the same province of Zhejiang) Ningbo PV facility's production of wafers - as well as overall capacity-were limited by the furnace size. However, the facility has developed a reasonably good market and acceptable pricing over the last year, serving applications as broad as navigation aids and SHSs for farmers and herdsmen. The center distributed approximately 50 36-W SHSs in 1992 and 1993, with two lights and one TV point. (One of the lights was rendered 
portable for the herdsmen.) In addition, the center distributed 24-W systems with two fixed lights and one TV. The customers were charged only for the appliances, not the power system. In 1997, the center got a contract from the Ministry of Science and Technology for a collaborative PV project with Zimbabwe designed to equip a village with PV power and drinking water. The SHS to be used in this project is 70 watts in capacity, and is sized to power four lights and a TV set. Eventually, 110 of these SHSs will be delivered to Zimbabwe. China will supply nearly all the hardware; however, the pump will come from Italy.

In addition to planning the hardware for the Zimbabwe project, the center has clearly thought out the whole infrastructure challenge. They plan to have the following three layers of service:

1. The Customer Level-The customer will be given clear indications regarding a system's status by a well-designed and clear indicator panel on the charge regulator. The customer will also be provided with user instructions in cartoon-strip form to avoid any language difficulties. In addition, the customers will be required to construct a box to protect the battery and routinely complete and supply a user log on the system's status.

2. The Village Level — One or more village-level, well-educated individuals will regularly visit each household in the village and check any problems, as well as explain to family members how to use the system. A teacher or student might be a suitable choice for this task.

3. The Service Agent-The service agent, located outside the village, would provide technical and engineering solutions that could not be handled by the village-level service. It was suggested that ZEDA was one electrical company that could fulfill this function.

In addition to setting up a suitable service infrastructure, the center will supply significant quantities of spare parts (for example, 100\% spare lights, $60 \%$ lighting parts and inverters, and 10\% extra controllers and other spares). The systems have been designed to have three days of autonomous operation during cloudy days. The end users are expected to make a $10 \%$ downpayment; once the system is installed, they will be expected to pay for their loads.

In addition to describing the role of the center and the status of the Zimbabwe aid project, a briefing was provided on China's PV industry. The 8th five-year national development plan was designed to achieve an efficiency rate of $14 \%$ and production costs of approximately $\$ 3-\$ 4$ per watt. Stable $7 \%$ a-Si devices have also been demonstrated; however, the Shenzhen a-Si plant was said to be nonoperational. (It seemed to be at least partially operational when visited later in the trip.) Indigenous EVA has also been under development and now has a projected life of 20 years. Based on estimated costs of grid extension of 3 million RMB and an estimated cost of solar installations of 500,000 RMB, various power units were installed in Xinjiang in 1996 (including the Bagamali village in the Gobi Desert). To date, grid-connected PV has not been adopted in China; however, the center lists gridconnected technology as one of their current development objectives.

The center has 15 staff and does not make any sales and does not have any technology licenses. 


\section{Dawa Solar Energy Company, Ltd. of Xining, Qinghai Xining, Qinghai. 9/10/98}

This private company, which was established in August 1997, is owned mostly by one retired individual. After eight months of operation, the company had sold approximately 1,800 SHSs. Twothirds of these systems are $10 \mathrm{~W}$ and the remainder are $18 \mathrm{~W}$. The 18 -W systems sell for between 1,350 and 1,400 RMB ( $\sim 9.4 /$ watt $)$ with 20 -amp-hour batteries. When the systems are supplied with bigger batteries (40 amp-hours), they sell for 1,450 RMB. The systems are sold mainly in Xinjiang, Qinghai, Tibet, Gansu, and Sichuan. Approximately 25\% of their output is sold in Qinghai, their home market.

Sales are achieved via independent sales agents, who buy the product and then sell it to end customers. In addition, they sell through the shareholder of this company and in the local solar shops. The sales value for the 12-month period is forecast to reach 3 million RMB.

The company does not sell 4-W systems. It has designed a 70-W system, but has yet to sell any. Apparently, the weakest part of the system is the batteries and the dc lighting circuits. The company makes its own light units and the batteries come from Wuhan. The company-selected batteries are unsealed lead acid.

The company makes its sales on a cash basis and does not have any credit programs. Sales are therefore limited, because many of the target customers do not have sufficient funds to make cash purchases of significant magnitude. To a certain extent, the size of the company's systems has been developed to meet the limited purchasing power of the nomadic herdsmen and farmers. The market for larger systems is believed to be very limited.

Although the company does not provide credit to the end users, it does provide some credit to their sales outlets. Initially the outlets pay 50\%; the remainder is collected when the sale is made to the end user. The company had many detailed questions regarding the status of thin-film PV technologies elsewhere in the world. The advantages of thin-film technologies used to make a quality low-wattage module were discussed. The company hopes to become a candidate company for the World Bank program, which should assist the market in becoming more standardized.

\section{Gansu GNERI Solar Electric Power Company, Ltd. Lanzhou, Gansu. 9/14/98}

The Gansu New Energy Research Institute has focused on solar energy (for electricity) development for the past 10 years; previously, the focus had been on solar thermal. Initially, Gansu paid more attention to the applications equipment for weather forecasting and telecommunications; however, in 1990, the company began to develop SHS. Funding for their development activity initially came from the provincial government and the provincial STC. As the products began to be commercialized, Gansu started taking loans from the bank.

In the 1990s, Gansu began to sell and distribute SHSs and found that the resources were very good, both in this province (Gansu) and on the border of Gansu/Inner Mongolia. In addition, the company discovered that the purchasing power of the farmers was sufficient for smaller systems (10-20 watts). Sales of 100-W systems to the herdsmen and farmers are also possible. In certain instances, subsidies were made available through the poverty alleviation program. This level of subsidy is a function of the particular area; however, it can range from between $20 \%$ and $50 \%$ of the price of an SHS. However, despite the fact that the market is very big and the systems are very welcome, there remains a need to 
further reduce system costs. There is therefore a need to increase production volumes and optimize system designs to achieve more cost-effective systems.

To date, Gansu has sold about 7,000 systems through its PV company, which employs about 36 people including the sales staff. The previous year (1997), approximately 600 systems were sold. This sales level seems very modest in comparison with the total volume achieved to date and the typical level of activity noted at other distributors. Apparently, the market was very good in 1993 through 1995; however, in 1996, the competition increased, leading to a reduced level of sales by this company. The accumulated market share was said to be between $30 \%$ and $40 \%$.

As is the case with the other distributors, Gansu sells the product via several different methods, including its own distributors and agents in remote areas where transportation is very difficult. Although some product is sold via credit, this amounts to only $10 \%$ of total sales. The credit mechanism functions via a middleman, who signs a contract with the end customer. The initial downpayment is $30 \%$ and the credit period is one year. The second payment (40\%) is made at the sixmonth point and the final $30 \%$ payment is made at the end of the year. Apparently, there is no interest.

Some problems have been found, however, with the credit program. Some customers take 24 months to complete the payments and in $33 \%$ of the cases, the payments were not collected. Sometimes the systems had failed to function, and in other instances it proved impossible to find the customer (nomadic herdsmen). As for system failure rates, it was estimated that $23 \%$ had minor problems; in $10 \%-15 \%$ of cases, the customers were said to have used the systems improperly. Failures occurred in lights, batteries, and, in some instances, in the PV modules. Maintenance is provided via the salespersons or agents, with the institute providing backup as needed. Training for the maintenance people is provided by the company and takes 15 days.

The institute's systems come with the following guarantees: modules, 15 years and batteries, 2 years; controllers and dc light circuits are repaired at any point in the life of the system. Circuit repairs are made at cost.

The GNERI Solar Electric Power Company was formed in 1990 as a collective; subsequently, it was changed to a stock company. The majority (80\%) of the stock belongs to the Energy Research Institute, which in turn belongs to the Gansu Science Academy (which is essentially part of the Chinese Academy of Sciences). The remaining 20\% of the company's stock is held by its workers. The majority of GNERI Solar Electric's sales are made in Gansu; the company also sells product to Qinghai and Sichuan, as well as the western sections of Inner Mongolia and Tibet.

The main barrier to growing the business is lack of capital. The company has access to bank loans, but only at interest rates of $7 \%-8 \%$. These rates are considered very high. For this reason, the company hopes to get soft loans from the IFC. On the other hand, the small private companies (such as those in Qinghai) have greater flexibility and lower costs for money (the latter reflecting interfamily loans or borrowing from private sources). It was not clear why private financial sources would not require competitive interest rates, unless one was talking about unrecorded transactions.

There are said to be no technical barriers and no obvious advantage to be gained from incorporating U.S. or European controllers/regulators with the SHS, despite the fact that many of the Chinese systems are known to fail due to the unreliable nature of the electronics. There seems to be no perception of the advantages that proven electronics would bring.

Similarly, the company sees no problem in general with the PV modules and routinely tests $10 \%$ of the incoming products. There was some comment on the low voltage of the cells delivered by the 
Ningbo plant, which incorporates more cells per module to reach the necessary voltage levels. Modules were judged to meet the necessary 15-year life typically required by current customers. GNERI did volunteer that the Qinhuangdao modules produced higher efficiencies than the Kunming-manufactured product, and that the Siemens modules that they had tested were of excellent quality. During this visit, many failed SHSs were in evidence in the workshop, including several units that appeared to have overheated batteries. The sealed units had excessively bulging cases and, in some instances, split cases.

\section{Gansu Provincial Electronics Industry Corporation Lanzhou, Gansu. 9/12/98}

There are many related companies that operate under the umbrella of the Gansu Electronics Industry. Lanxing Electronics Corporation and Lanxing Electronic Apparatus Factory are the main elements of the provincial, state-owned Electronics Industry Corporation; under them are a myriad of smaller enterprises including the Lanxing PV Company, Lanxing Production Base, a Research Center, an Energy Saving Lights Company, and the Zhongxing PV Company. None of these factories currently make PV modules; however, there is a Phase II plan to set up a 2-MW PV production plant and a Phase III plan to increase the size of the plant to $4 \mathrm{MW}$. The factories claim to have about 20 years of PV systems experience.

In the meantime, the aforementioned factories do make inverters and controllers, as well as dc lights and fluorescent tubes. In addition, they manufacture energy-efficient water heaters for cost-effective hot showers. The used water is recycled to partially heat the incoming water.

The company supplies both SHSs and larger PV systems for powering satellite TV units. Last year (1997) they supplied some 1,000 systems including some satellite TV systems, butter separators, and other systems. The company employs about 1,000 workers and has approximately 24 separate corporations.

The company is seeking to extend its operations into Tibet and several neighboring provinces. It will also target certain industries such as railways and communications. Of the 300,000 homes that remain unelectrified in this province (Gansu), only about $30 \%$ can afford PV systems at current prices. The $30 \%$ figure was derived from market survey data. For example, a herdsman's annual income is about 2,000 RMB ( $\$ 250$ U.S.), whereas a farmer might have an annual income of 1,000 RMB ( $\$ 125$ U.S.). The larger systems, such as the $100-\mathrm{W}$ power units, are sold to hospitals, schools, and temples. The selling price for a 10-W system is approximately $980 \mathrm{RMB}(\sim \$ 12.25 \mathrm{U} . \mathrm{S}$./watt). Individual customers must pay the total price at one time, whereas agents are allowed to pay in installments.

Typically, the systems components are sold with guarantees as follows: module, 10 years; controller, 2 years; battery, 2 years; lights, 1 year. Repairs are undertaken at the factory at no charge during the first year. Maintenance is also provided by the sales outlets.

In the larger-systems market within Gansu Province, the company believes that it can capture around $50 \%$ of the market. For smaller systems $(<20 \mathrm{~W})$, a $33 \%$ share may possibly be attained. The value of the company's PV sales is approximately 8 million RMB annually. As for the scale of PV production, they do not believe that $15 \mathrm{MW}$ is suitable for China. They need to take it one step at a time, starting at much smaller capacities. 
According to Gansu Provincial, the weak part of its PV operations is a lack of modules. The company currently makes most of the added-value components but buys the modules from other suppliers; it believes that producing its own modules would lead to cost savings.

The PV systems marketing is done by the Lanzhou PV Company. It has five sales points in northwest China: Gansu (2), Qinghai (1), Inner Mongolia (1), and Xinjiang (1). It has been suggested that there is a need to do more marketing and advertising, as well as to set up more sales offices to better serve the vast markets within Gansu Province. The company's goal this year is to sell 1,200 systems. Up to this point in the year (1998) they have sold 600 units. When discussing the projected cost reduction that might be achieved by producing the modules themselves, it seemed that there could be a government subsidy of around $\$ 1-\$ 2 /$ watt based on the social benefit, which alters the profitability question.

This group of companies is very interested in cooperating with U.S. technology firms. When they asked the appropriate national officials, they were instructed to start such activity via the U.S. embassy. They are eligible for long-term loans or grants to assist in any joint venture; their excellent relations with the regional and central governments may lead to quicker or better assistance.

\section{Gansu PV Company Ltd. Lanzhou, Gansu. 9/13/98}

In 1988, PV experienced an increase in scale in China. Initially, the government provided direct assistance for applications such as weather forecasting and broadcasting; around 1991, it provided financial aid to the end customers in forestry to establish 100 watchtowers. In 1992, the Gansu provincial authorities provided PV power units to the highway maintenance teams in unelectrified parts of the province. Also in 1992, the Solar Electric Light Fund (SELF) and Mr. Wang, chairman of the Gansu PV Company, established a partnership (majority Chinese) to help provide systems financing to unelectrified farmers and herdsmen. The plan was to allow customers to make payments over an extended period of time ( $\sim 10$ years), thus allowing them to earn additional monies through the sale of livestock or eggs to cover the purchase of the complete PV system. The initial downpayment of 400 RMB was collected at the time of installation; however, it was later found that there was great difficulty in collecting the remainder of the payments. There were apparently various reasons given by the end customers for being unable to make the remainder of the payments, from sickness to tuition fees.

Mr. Wang has been developing a trade-up program whereby the customer purchases a small system outright at the beginning and subsequently pays extra to trade in the smaller system and receive slightly larger systems as and when funds permit. Although this approach has the advantage of limiting the requirement for credit, it does have very high transaction costs associated with the many visits/trades. There is also a cost associated with discounting the reclaimed systems to ensure that they are also sold to end users. An initial system might be as small as 6 watts, commanding a price of $700 \mathrm{RMB}$; subsequently, upon payment of an additional $600 \mathrm{RMB}$, the customer gets a 10-W system in exchange for the used 6-W unit. The trade-up program started in 1996 during the second half of the year; at the time of the visit, between 3,000 and 4,000 systems had been sold using this approach.

During the first year of operation in the field, only $4.7 \%$ of the systems failed. Given that the founder's name is on the product, this supplier insists that they provide a very reliable product. Lights are guaranteed for one year and replacements can be obtained in local stores at $\sim 3.1 \mathrm{RMB} / \mathrm{unit}$. The batteries, which are guaranteed for five years, are sealed and maintenance-free. They are operated with a low-voltage cut-off in the charge regulator. The system itself is designed to have no more than a $20 \%$ depth of discharge under normal operation. Apparently, if the battery fails within this five-year period, the customer gets credit for the unused part of the five years and can purchase a replacement battery with a pro rata discount. Many of the systems supplied by Mr. Wang that use this battery technology 
have apparently been in operation for at least four years. At the time of the visit, the 205 systems supplied under the NREL collaboration program were being evaluated for reliability.

As to barriers to future business growth, Wang identified the cost of the modules as being the number one barrier as compared to the levels of income of the target customers. The difficulty in establishing an effective credit distribution system is seen as the next most important barrier to business growth. It was suggested that the Agricultural Development Bank may be an appropriate body to assist with this rural credit program. To date, the bank has not agreed to deal with this type of market; it seems unlikely that the bank would agree to pick up the very high transaction costs associated with low unit-value sales to a dispersed customer base. It appears likely that if a credit scheme involving the Agricultural Development Bank were to be developed, there would be a requirement for some other body to buy down the transaction and potential bad-debt costs. Another concern expressed by this distributor is that international aid programs such as the Dutch/Xinjiang project might plan to sell PV systems at a significant subsidy, thus destroying the market for full-price systems sales.

\section{Gesang Solar Energy Ltd. Xining, Qinghai. 9/10/98}

This is a private company run by Tibetan women, with a mostly Tibetan staff. The main sales outlet based in Tibet is also run by a woman. Established in 1993, the business was originally focused on supplying herdsmen (especially herdsmen of Tibetan origin). Over the years the wattage of a typical system has been reduced in response to market conditions/demands. Today, they sell more 4-watt systems; however, in 1995 the average was $20 \mathrm{~W}$. In addition to serving the small-systems market, they have also found a need for larger (30-100-W) systems for wealthier customers. There are eight sales offices operated by the company in the three provinces/autonomous regions (Qinghai, Tibet, and Sichuan) that they serve.

The company's primary sales are to Tibetans, either in Tibet or in largely Tibetan regions within the other provinces. Although only $20 \%-30 \%$ of their product goes into the autonomous region of Tibet, a full $95 \%$ of their product sells in Tibetan-dominated areas. The company has only one assembly point in Xining. The staff who manage the sales outlets spend between two and three months at the Xining center undergoing training before returning to their posts. The company's three main focuses are quality, price, and after-sales service. Price competition is the biggest problem they expect to confront next year. They see the tasks of making sales and providing effective after-sales service to remote customers as costly. The ever-increasing competition obviously reduces margins.

The company employs 21 people, many of whom are relatives with limited higher education and managerial experience. They have not yet managed to establish sufficient statistics to enable them to run the business as effectively as they would wish, nor have they established sufficient rules and systems to control the business. The establishment of good administrative systems and statistical controls, however, is within their longer-term plans. They admit that their technical expertise is not good. And finally, they note that, in general, Tibetan purchasing power is not high.

Unlike most of the other manufacturers, this company is operating a credit sales system. Having made over 400,000 RMB ( $\$ 50,000$ U.S.) sales on credit, they have only experienced bad debts of $2,000 \mathrm{RMB}(\sim 0.5 \%)$. In many instances, customers who are known personally to the salesperson pay a $10 \%$ downpayment, and provided the remainder is paid within five months, there is no interest charged. In some instances, due to hardship, the final payment was made in sheep. In another case, when a family could not pay, the system was reclaimed. Sales documentation identifying the various customers' indebtedness was signed by the customers using a thumb print. This peer-pressure approach 
to credit sales seems somewhat similar to the Grameen and Ramakrishna Mission experiences in Bangladesh and West Bengal, India, respectively.

Total sales for the company amount to 5 million RMB; the extent of credit sales would be increased if they had access to more funds. And despite the claim that the company lacks statistics, I was shown a very detailed graph of the seasonal sales activity, which begins to pick up when medicinal plants are sold in July and sheep are sheared in August. Next year's (1999) forecasts show sales reaching 7 million RMB and total volume reaching 7,000-8,000 systems. The company serves approximately $20 \%-30 \%$ of the Qinghai SHS market annually.

As for market potential, about 2 million —or approximately 400,000 families — in Tibet are believed to be without electricity. After many years of dissemination of PV systems, approximately $80,000-100,000$ families now have systems.

The company's biggest technical problem is the system battery, which only lasts for two years in many instances. In addition, the circuits for the dc lights are not reliable enough. This company would like technical guidance and advice.

\section{H.K. Company-Scheme Enterprises Holdings Ltd. Foshan, Guangdong. 9/25/98}

This private technology company, with eight Chinese shareholders (one in Hong Kong and the rest on the mainland), operates under the auspices of a Provincial High Technology Enterprise. It operates under the leadership of the Foshan Committee of Science and Technology, which affords the company certain provincial benefits. Nevertheless, the committee does not impose any control over the company. All decisions are made by the private board and management. The main products of the company include uninterruptible power supply (UPS) systems, inverters, and some batteries. They cooperate with Santak of Honolulu, Hawaii.

Established in 1986-87, the company has a staff of 224; there are 14 subsidiary companies. They develop, manufacture, sell, and maintain inverters (medium and large) for such customers as the Post Office in remote regions that include Tibet and Xinjiang.

The office uses H.K. Company's MET equipment in Tibet. Given that many of their products have been proven in the challenging Tibetan environment, they feel confident that they are suitable for applications anywhere within China. Their technology makes use of pulse-width modulation and many semiconductor devices imported from the United States to achieve the desired overall system performance. In addition, the company incorporates smart-controlling technology in its systems. Although technology was originally transferred from Santak, there is no ongoing license fee; however, there is apparently a mutually beneficial business relationship with Santak.

In 1994, the company's sales were about 90 million RMB, increasing to in excess of 100 RMB in 1995. This level of sales was maintained in 1996 but declined slightly in 1997. This decline in sales was justified by the apparent worsening of the national economy in China.

The production plant for the UPS and inverters was just being moved during the visit. The new factory, which represents an investment of about 8 million RMB, is located approximately 15 miles from the company's older headquarters. The factory and R\&D facility have been purchased by the company; this should yield cost savings. (The facility was previously rented.) The company expects to see a few percent reduction in production costs and a general improvement in morale from the very attractive new 
buildings. The recently moved production line also looked rather impressive, as did the quality of the electronics boards and systems under production. Overall annual production is about 60,000 systems, with different products being run on a batch basis as needed.

\section{Hybrid Systems Site Visit to a Herding Area 250-300 km from Hohhot, Inner Mongolia. 10/10/98}

This all-day trip, guided jointly by the New Energy Office and Professor Liu Zhizhang, director of the Inner Mongolian Energy Institute, provided a clearer picture of just how remote the unelectrified herding areas are, and of the way of life of some of the herdsmen and their families. This region, which was selected because of its relative nearness to Hohhot, was still 4-5 hours away from Hohhot via jeep (despite the relatively well constructed and maintained roads that wind through a mountain range). During most of the journey to the first wind-solar hybrid installation, there was a steady stream of tractors, trucks, tilling machines, and motorized rickshaws on the other side of the road leading to Hohhot. Because many of these vehicles were heavily loaded down with farm produce and passengers, and therefore limited to a $15 \mathrm{~km} /$ hour pace (at best), one assumes that their journey would take at least a full day in one direction, and possibly two. Finally, after having seen the last of the grid lines about one hour previously, we arrived at the first herdsman's house. The brick one-story house, covered with a mud, straw, and animal waste, had a $100-$ W U.S. PV array on the roof, and a $300-\mathrm{W}$, locally manufactured wind turbine at the rear of the house. Fortunately, the house was quite near to (and readily visible from) the road, so locating the site proved straightforward. The system had been installed in 1995, and had only stopped working on one occasion due to a faulty inverter that had been supplied by the Natural Energy Institute for repair. The nearest Energy Service Center, however, was in Hohhot (several hours away via Jeep). The center, in any case, would not have been able to carry out this type of repair. And there was no chance of phoning the service center or Hohhot, because the herdsman has no phone. As for the general quality of the modules, it looked as if there had probably been deterioration in the encapsulation, as well as in some of the contacts between cells.

In addition to the hybrid system, which relied on the owner to disengage the wind turbine if the PV was supplying ample charging power, the house was equipped with a heating stove and two cook stoves that were fueled by dried animal dung. The herdsman had 40 cattle and 600 sheep, some of which were kept in a pen near the house in order to build up a compacted layer of dung over time. This layer would then be cut and dried and used for fuel. There was some small amount of coal stored to the rear of the property; however, coal is both relatively expensive and difficult to obtain in this remote location.

Because it was not visible from the road, the second hybrid site did not prove so easy to find. Located approximately $1 \mathrm{~km}$ across the fields, the structure was built of brick with a tile roof. The house, which was significantly larger than the previous one we had visited, was home to a recently deceased, successful herdsman's widow, family, and workers. The hybrid system was similar in size to the previous unit; it had the same vintage U.S.-supplied PV modules and a 300-W wind turbine manufactured in Inner Mongolia. Because there was nobody at home when we arrived, it was not possible to view the electronics and batteries for this system. After leaving the site, we met the lady of the house on her motorcycle returning from rounding up some previously lost cattle. Apparently, this hybrid system had also had some inverter problems, requiring the unit to be returned to the supplier in Hohhot ( $300 \mathrm{~km}$ distant). The system had originally been purchased for 6,000 RMB in 1995 and had its batteries replaced the previous year. The cost of the regular battery was said to be 1,000 RMB; the owner had apparently chosen to purchase a superior-technology battery for another 2,000 RMB. Apart from the initial inverter problem, the owner said that the system was generally working well.

\section{Inner Mongolia Huade New Technology Company}




\section{Hohhot, Inner Mongolia. 10/11/98}

Developed from the Livestock Machinery Research Institute, which started in the 1960s, this company began with $50-\mathrm{W}$ and $100-\mathrm{W}$ wind turbines in 1989, and participated in a German special energy program. Huade established wind and solar test sites in several areas in Inner Mongolia. Of the total of 13 sites established, all had wind measurement equipment and 3 or 4 included solar test equipment. Most test data was collected for at least one year, and in some instances data was collected for a total of three years. Subsequently, Huade Company participated with the SMA company in deploying 5-kW demonstration (subsidized) wind-diesel battery systems. Later on, they installed 13 or 14 commercial systems, including a 2-kW village power solar system in the desert in the south of Inner Mongolia, and 10 90-W solar home systems. Huade Company also installed the power systems for four of the first microwave relay stations in Inner Mongolia. They also manufacture microwind chargers of 300 and $500 \mathrm{~W}$ in capacity. On the PV front, they only participate in the engineering, installation, and maintenance; they do not manufacture PV modules. The biggest PV system that they have worked on was $2 \mathrm{~kW}$ (for a microwave relay station). And their PV activities have been limited to this particular autonomous region. The smaller SHSs that are sold in the northwestern provinces such as Qinghai and Gansu ( $\sim 10$ watt) are not at all popular in this region. Perhaps the herdsmen have higher income levels, making larger systems more attractive. At a minimum, the herdsman wants TV as well as lighting, which in many instances includes a satellite receiver.

Wind systems have been promoted in Inner Mongolia for over 20 years, so the rural herdsmen are familiar with these systems. It was evident from the site visits that were made the previous day that almost every house in the nonelectrified rural areas had a small wind turbine; many had more than one machine in action. Today, hybrid wind-PV is being promoted; the typical herdsman has a system comprised of a $300-\mathrm{W}$ wind generator and a 100-W PV array. A large inverter is often incorporated as well to ensure that the system is capable of starting a freezer. Huade Company produces various controllers and inverters, as well as some smaller PV systems (10 W and $20 \mathrm{~W})$; however, to date, fewer than 100 systems have been sold.

As with many of the other institute-related companies that have been visited during this program, the Huade Company is a state-owned company belonging to the institute (see Inner Mongolia Wind Generating Company). They have excellent cooperation from the German ministry and have one German expert on secondment with them. The current project will be completed in 1999. In addition, various European and U.S. modules were in their display area, including modules from ASE Americas, Inc., and Photowatt. Huade has some form of agency relationship with one of the module suppliers.

Under the Eldorado program, the German government provides subsidies of up to $70 \%$ of the system cost. The current program calls for the installation of several stand-alone battery systems (wind-diesel hybrids), including two demonstration systems and two semicommercial units, at least one of which is destined for an island off the southeast coast of China.

Huade has probably sold/installed $150 \mathrm{~kW}$ of total PV; the maintenance of these systems is either handled by themselves directly or a partner company or person designated to care for a particular system. Initially, spare parts are supplied to the identified maintenance organization, and any replaced parts will be sent back to Huade for repair. The Huade Company has a total staff of 30, of which more than $50 \%$ are engineers. Many of the staff are directly charged to the collaborative German project. Wind system sales amount to a few hundred machines (300-500 W). This year (1998), however, is not a typical year given the significant decline in the selling price of cashmere (the rural region's major cash crop). Even with the cashmere price at $50 \%$ of normal levels, it is still difficult for the herdsmen to sell their product. 
The recent decision to electrify all the townships as part of the 40th anniversary of the formation of the autonomous region of Inner Mongolia has provided considerable additional work to the Huade Company. This task artificially increased the number of village systems that they installed and required that they complete all the installations in time for the anniversary. Huade Company hoped that the World Bank program would allocate some of the anniversary program money to promote, advertise, and launch a market, rather than simply relying on subsidies. In regards to the Brightness Program launched by the State Planning Commission, there were as yet no signs of anything happening. It was hoped that this program could do something for manufacturing and market development, as well as science research activities.

Meanwhile, Huade continues to experience technical problems with inverters. They recognize the problem, but have limited resources to apply to its solution. Another problem in developing a sustainable market is the seasonal nature of the typical customer's income (either from animal slaughter or from wool cutting). There is therefore a certain window of opportunity to make the sale, or the herdsman will buy some other item. In addition, there is apparently little focus on savings; if they do not buy at that peak time then they must wait another 12 months.

Huade has had limited success with a credit program. The initial payment is $50 \%$ up front and the rest of the payment is required after one year. Approximately $90 \%$ of the customers kept to the payment program, with only a few being delinquent. In this credit program, a regional partner is essential. Haude sells through the regional partner to the end customers, who are usually clustered in the area adjacent to the selected partner. Selling one system in a remote area is impossible to control. The customers know that the payment collector/regional partner cannot remain in the remote region for very long, so they tend to develop many ways of avoiding payment till after the collector's departure. When it becomes necessary for a system to be repossessed, the customer still (according to the contract) has to pay the cost of the battery and the installation work.

The main barriers to this business's growth are money, technical limitations, and state ownership. Loans are difficult to obtain and costly, with interest rates as high as 9\% (plus added costs) even when bank loans are obtainable. The development of reliable inverters is limited by their technical expertise and limited resources. A small company cannot put together the effort required to produce a reliable, cost-effective inverter.

The third barrier identified was state ownership. The management, administration, and the physical resources at the institute appear to be restricting potential growth. Despite these negatives, however, state ownership does presumably bring a variety of benefits. For example, they are allowed to enter into joint venture arrangements with the private sector. As of yet, however, they have not found a suitable partner organization. Meanwhile, even though the indigenous technology was said to be out of date and in need of improvement, they could still sell improved small $(<50 \mathrm{~W})$ modules in China, in addition to possible export opportunities. If there were an opportunity for a joint venture with an international partner, planned investment funds might be partially matched from state (provincial) funds.

Huade Company has purchased wind blade technology and work is under way to develop the skills to locally manufacture a blade for a 5-kW machine. Discussions are under way with SMA regarding the possible development of a 4-kW sine-wave inverter technology. They also produce a 4-kW square-wave inverter, which apparently has a $90 \%$ efficiency at rated power levels. This efficiency measurement was carried out in-house; to date, the inverter has not undergone any testing by a third party, nor has any certification been obtained. As with other suppliers, they provide maintenance free of charge for the inverters during the first year; after that time, any repairs are undertaken on a cost basis. To date, they have shipped several hundred units and some have been in the field working reliably since 1994. 


\section{Inner Mongolia Wind Power Generating Company Hohhot, Inner Mongolia. 10/11/98}

This company was formed in 1995 from parts of two institutes: the Institute of Wind Power Generation, which was established in 1975, and the Wind Power Office, established in 1986. The Wind Power Generating Company's mission is to manage the four wind farms in Inner Mongolia, as well as any further investment in wind plant in Inner Mongolia. The power supplied by the wind farms is all sold to the grid. In 1997, the installed capacity was $39,775 \mathrm{~kW}$, and the target for the year 2000 is 200,000 $\mathrm{kW}$. The cost of generated electricity is a function of the size of the installed plants. The plant in Xilin is somewhat more costly than those in Zhurihe, Shangdu or Huitengxile, where the installations are of larger capacity. The best three farms generate electricity at $\$ 0.07 / \mathrm{kWh}$ while the fourth plant at Xilin has a higher cost at $\$ 0.075 / \mathrm{kWh}$. The depreciation period is $8-10$ years and the maintenance costs contribute $\sim 5 \%-6 \%$ to the electricity costs. Recently, Inner Mongolia has fallen to second place in terms of the largest wind capacity in China; however, they expect to be back in the number one slot in the near future.

As much as $33 \%$ of all the wind resources China are in the autonomous region of Inner Mongolia. The initial cost of wind-generated electricity will be higher than that of coal-fired power; however, the state expects to gain the understanding of the public. It is anticipated that only $60 \%$ of the generated electricity will be consumed in Inner Mongolia, the remainder will be exported to Beijing and eastern China. It is important, however, that they gain policy support for their efforts, given the relatively higher cost of wind generation versus conventional thermal generation. The regulations introduced by the Ministry of Electricity and Power in 1994 allowed for the extra cost of renewables generation to be added to the cost of coal, and for additional installation of grid-connected wind farms. It is forecast that, as the cost of coal-fired generation increases with the increased cost of plant and the addition of pollution controls, together with the ongoing reduction in the cost of wind generation as technology improves and scale increases, the costs of both power sources will become equivalent in about 15 years. There are as many as 10 suitable wind sites in Inner Mongolia (wind speeds $>6 \mathrm{~m} / \mathrm{s}$ ); at present, only 4 of those sites have been developed. The total planned installed capacity by the year 2020 is 2.68 gigawatts $(\mathrm{GW})$, and they expect to be able to beat this target. Apparently, they do not anticipate any problems in obtaining the necessary financing to cover their plans to the year 2000.

Wind Power Generating Company concentrates on grid-connected systems and does not get involved in the electrification of towns and villages away from the grid. It was estimated that less than 20 towns in Inner Mongolia are served by wind-diesel hybrids. The estimated cost of grid extension to a village is $\$ 10,000 / \mathrm{km}$; typically, a small village might have a total of 50-60 homes and be located $50-60 \mathrm{~km}$ from the grid. On a larger scale, there is a plan to install a hydro-wind hybrid (60 MW of hydro and $30 \mathrm{MW}$ of wind). The German government would provide the loan to cover six wind turbines for this project.

When asked if they had considered the co-siting of wind and solar systems (as has been discussed in eastern India), employees of Inner Mongolia Wind Power raised their concern as to the large waterheating requirement at their training/demonstration site in Huitengxile, where as much as $1.4 \mathrm{GWh} /$ annum are taken to power their hotel from the wind farms' total annual output of $80 \mathrm{GWh} /$ annum. Solar thermal would seem worth considering, because there is ample solar resource in the region; however, the temperatures can drop to as low as minus $40 \mathrm{C}$. The company requested information on solar thermal technologies in the United States that could function under such extremes of temperature. 


\section{Inner Mongolian New Energy Office Hohhot, Inner Mongolia. 10/9/98}

In addition to the management staff of the New Energy Office, this meeting also included Professor Ji Binghou (director of the Chinese Photovoltaic Speciality Committee) of the Physics Department of Inner Mongolia University. Inner Mongolian was established in 1980 as the New Energy Leader Group, which was responsible for planning and coordinating the development of renewable energy within Inner Mongolia. The company now has considerable involvement in all associated areas. The New Energy Office is now responsible for developing the corresponding overall program, and planning for research, production, demonstration, and promotion of renewables in Inner Mongolia. The various aspects of the plan are the individual responsibility of certain ministries/commissions; for example, the research plan is developed by the Science and Technology Commission, while the budget is the responsibility of the Economic and Trade Commission.

The development of renewable energy began in the 1970s based on local environmental research. Total land area in Inner Mongolia is 11,800 square kilometers, while herding areas are about $74 \%$ of the total. There are two evident shortages in Inner Mongolia: transportation and electricity. Given the nature of the region, grid extension is not feasible; for this reason, the government has been pushing renewables for 20 years. The local government has a subsidy policy to encourage the adoption of renewables. For household systems that might incorporate $100 \mathrm{~W}$ of wind power and $16 \mathrm{~W}$ of PV, there is a subsidy of $200 \mathrm{RMB}$ for each component, making $400 \mathrm{RMB}$ for the combined system (and, for larger systems, a pro rata subsidy). Therefore, a 300-W wind system could get a 600 RMB subsidy and a 32-W solar PV unit could get a 400 RMB allowance. To date, the total subsidy provided under this scheme has reached 26.5 million RMB. The primary focus of the program has been to provide the herdsmen with appropriate systems to meet their daily needs. Subsequently, the larger systems can add to the productivity. The overall promotional scheme was developed in five steps: research, production, promotion, technical service, and training. The research was originally based on inputs from the herdsmen regarding their specific needs.

In addition to the subsidy program, the Inner Mongolian New Energy Office has developed New Energy Service Stations in 50-60 rural counties within the autonomous region. These stations have trained personnel capable of installing and maintaining systems and providing training to the end users such as the herdsmen. There are about 100 such stations, including some in the city counties. Small wind systems have been developed within Inner Mongolia, and machines are now available to provide $50,100,200,300$, and 750 watts; larger machines for 1, 2, and $5 \mathrm{~kW}$ are also available. In addition, development has also focused on wind pumps, PV cells, solar water heaters, and solar cookers.

The production capacity for small wind units is currently at approximately 13,000 systems per year with five or six small active wind manufacturers within the region. The Inner Mongolian wind systems are sold to 20 provinces in China and exports are made to Mongolia, Indonesia, Japan, Europe, and the United States. In one international assistance project, they supplied about 500 small wind systems to Indonesia. These systems were $50 \% 100-\mathrm{W}$ and $50 \% 300-\mathrm{W}$ units. The largest wind machine manufacturer in China is the Shangdu Herding Machinery Plant located in Shangdu. There is only one PV manufacturer/assembler, which is based in Baotou; however; the Baotou Solar Energy Equipment Plant apparently assembles under some sort of contract arrangement for the Ningbo Solar PV plant. Currently, there is no assembly due to some contractual differences between the two parties.

The renewables subsidy has been in operation since 1986. The subsidized 16-W PV and 100-W wind units were developed based on the comparative selling prices of both technologies at that time (700 RMB for a 100-W wind system and 800 RMB for a 16-W PV unit). Today in Inner Mongolia, 
the herdsmen tend to opt for larger PV units up to $200 \mathrm{~W}$, as the $16-\mathrm{W}$ systems were not powerful enough. The subsidy program has evolved over the years, having originally been based on printed cards that were given to the herdsmen by the various county offices. The card (coupon) could be exchanged for 200 RMB. Unfortunately, the cards were sold to other herdsmen. So, in 1987, the Finance Bureau distributed money to the county-level finance bureaus. Since 1988 the subsidy has been routed directly to the manufacturers; as a result, selling prices have been reduced by 200 RMB per unit based on a predefined development plan. A particular county will have an allocation of, say, 300 systems in one year. Therefore, if one sells 400 systems in that county, the subsidy can only be claimed for 300 units. Finally, at the start of each year, a participating system supplier would indicate the number of systems it was planning to ship, and at the end of each year an audit would be carried out to ensure that there had not been any miscounting or misrepresentation.

The subsidy is only available to "qualified" suppliers. At the start of the program, about eight or nine companies applied to participate; however, so far only five or six have been qualified. Apparently, the strength of the subsidy program is so significant that the unqualified vendors tend to go out of business.

As of 1986, there were 420,000 households within the Autonomous Region of Inner Mongolia that were unelectrified. To date, 120,000 have been electrified, leaving 300,000 as a potential market. The level of subsidy has been steadily decreased over the years from 4 million RMB per annum in 1986-88 and 2 million RMB per annum between 1989-90, down to 1.5 million RMB per annum between 1991-97, which equates to 7,500 units of subsidy per annum. In addition to the system subsidy, some payments are also made to the battery manufacturers to reduce the selling price of batteries for renewables systems. The single battery manufacturer in Inner Mongolia is based in Baotou and is an automotive battery supplier to Audi.

The least reliable part of the PV system today is still the battery; however, in the larger systems it is the inverter that causes most of the reliability problems. There is only one manufacturer of lights in Inner Mongolia, so many of the lights are imported from other provinces. The best lights can last up to four years and the worst might last one or two months. There is a study under way to determine the best performance/cost ratio for such lights.

\section{Institute of Policy and Management, Chinese Academy of Sciences Beijing. 9/8/98}

The Chinese Academy of Sciences is involved in the development of PV technologies in China and was able to provide an overview of the current and predicted PV markets. The institute has provided complete PV power units, the largest of which $(100 \mathrm{~kW})$ had been installed in Tibet about four months previously. Despite the active use of PV power for communications, the grid-connected market is not expected to develop any time soon. The PV-for-communications market is expected to grow quite rapidly because the industry itself is growing rapidly within China; and for many of the applications, $\mathrm{PV}$ is the most cost-effective and reliable solution. It was estimated that the communications segment of the market could grow to a scale of several megawatts per annum during the next five years, and that the SHS market could contribute 7-8 MW in total over that period. The market for SHS is very bright provided the quality is controlled soon. Government power station projects can be expected to contribute about $300 \mathrm{~kW}$ per annum to the total PV market over the next five years. Typically, two or three PV power stations are funded each year. Several PV development labs and businesses were highlighted, including the Jike Company in Beijing and the Institute for Non-Ferrous Metals (also in Beijing). Similarly, the Qinghai New Energy Institute in Xining was recommended as being a valuable site to visit. 


\section{Jike Energy New Technology Development Company Beijing. 9/8/98}

Beijing Jike, established in 1982, is one of the units doing research and development (R\&D) on photovoltaics; it is probably the leading PV systems engineering company in China. It has provided and installed many of the significant PV systems throughout China, including PV power plants up to $100 \mathrm{~kW}$, large-scale wind-PV hybrid power stations, and wind-PV hybrid home systems, as well as cathodic protection for oil pipelines and sluice gates, PV power stations for communications, railway/highway signaling systems, and PV supplies for advertising and schools. In addition to hardware (including sine- and square-wave inverters and pumps), Jike Company also provides software products for PV system sizing and design.

Jike Company typically supplies around $200 \mathrm{~kW}$ of PV per annum, with $50 \%$ of these sales in the telecommunications segment, $10 \%$ going for rural electrification, and the remaining $40 \%$ supplied to industry. The company expects to capture $50 \%$ of the PV-for-communications market in China annually. Typically, their PV systems are expected to last 20-25 years, with indigenous modules such as those from Qinhuangdao and Kunming. Currently, there are said to be domestic sources for both ethylene vinyl acetate (EVA) and Tedlar. Modules typically sell for 40-45 RMB per watt; the lowest price is around $38 \mathrm{RMB}$ per watt.

Jike Company frequently works on international collaborative programs such as the Sino-German project in northeast China, which involves 350 SHSs (100 100-W and $25050-\mathrm{W})$ that make use of ASE Americas, Inc., modules. Jike judged that failure rates on such systems are very low; however, the weakest system components in general are the dc light circuits. Typically, batteries are not specifically designed to withstand deep discharge operation.

\section{New Energy Development Company, Ltd. Xining, Qinghai. 9/10/98}

This is a private company owned mainly by the founder, and in part by a few external investors and company workers. Established in 1996, the company now employs 35 people and sells between 4,000 and 5,000 PV systems per year. Typically, these are SHSs between 10 and $20 \mathrm{~W}$. Forty percent of their sales are within Qinghai province and the remainder are sold in Tibet, Inner Mongolia, Gansu, and Sichuan. Some product is also exported to bordering countries such as Nepal, Mongolia, and Pakistan.

In common with many of the other distributors in the region, the New Energy Development Company has several different types of sales outlets, including:

1. Local solar shops, of which there are many; they take the product into stock and then pay the company as and when the product is sold.

2. Local shops that pay $40 \%-50 \%$ of the cost of the product at the time of supply and then pay the remainder as and when they sell the product.

3. Local shops that act as agents for the company.

4. Shops that buy and sell at arms length.

If the PV system fails in any way, the maintenance is provided by the sales outlet/shop. During the guarantee period such maintenance is free of charge; however, subsequent service is provided at cost. The box is guaranteed for 10 years, the lights for 2 years. Typically, the company expects the batteries to last for three years and will replace the battery free of charge if it fails in the first year. In common 
with many of the other distributors, New Energy Development does not use other companies' designs under license and has apparently developed all its own designs.

Typically, indigenous modules are sold at $\$ 5 / \mathrm{W}$, whereas imported products such as Siemens modules sell at around $\$ 6 / \mathrm{W}$. Their business, which is currently profitable, consists almost entirely of SHSs. The company estimates that it has approximately $30 \%$ of the market in the province of Qinghai. It is further estimated that the largest supplier is the Qinghai Provincial Solar Electric Power Company. This private company is currently focusing its efforts on trying to deliver a quality product; indeed, it expects to be the highest quality supplier in their market. Sales amounted to 4 million RMB last year.

The main challenges that this company sees for its PV business are financing (no credit), marketing channel development, and technical problems. The company would like to participate in the largersystems market for military bases and telecommunications/railway systems. New Energy Development would like to collaborate with U.S. firms, although it has yet to do so; rather, it is seeking to expand any joint venture relationships gradually. In their view, the principal technical problems are controllers, batteries, and lights. The 6-W, single-light system with a single 9-W tube sells for $500 \mathrm{RMB}(\sim$ \$10/W U.S.).

\section{New Energy Office Renewables Demonstration and Test Center Hohhot, Inner Mongolia. 10/9/98}

This demonstration and test center has many working renewable energy systems. It is located on the outskirts of the city of Hohhot in a futuristic building complex that houses a meeting facility and a room for the testing areas, which have not yet been equipped. This meeting itself was attended by Professor Liu Zhizhang of the Inner Mongolia Natural Energy Institute.

The Natural Energy Institute focuses on two areas: renewable energy, including wind-diesel hybrids, and conventional energy. Included in the renewable energy category is the development of solar thermal water-heating technology for water heater systems that can function reliably in the colder northern area of the autonomous region. The university also carries out testing of all renewable energy equipment and analyzes the collected data. The largest hybrid that they have worked on in the region for household use is a $300-\mathrm{W}$ wind, 200-W PV unit. For small towns the wind-diesel hybrids will be $25 \mathrm{~kW}$ of wind coupled with $24 \mathrm{~kW}$ of diesel. Although they have not installed such a system to date, they have just completed the technology development.

One of the problems associated with the promotion of wind-diesel hybrids for village power is the lack of people able to handle the system management. It is a much simpler matter for households, because the system is purchased by the house owner, who accepts responsibility for managing the system. After several questions regarding the nature of the hybrid control system, it became apparent that no controller is incorporated in such systems. It also became apparent during a field trip the following day that, when there is enough solar radiation to charge the battery (in a wind-PV hybrid), the wind generator will manually stall to reduce the input.

For one of the larger PV installations in Inner Mongolia, which was developed using German aid money, the customers/end users pay for the electricity and must purchase their own loads. The unit price of electricity is approximately $1.2 \mathrm{RMB} / \mathrm{kWh}(\$ 0.15 / \mathrm{kWh}$ U.S.). These individual solar home systems have meters that are read by the same person who is responsible for the system maintenance. (The meters cost $\sim 50 \mathrm{RMB}$ [\$6.25 U.S.] and the typical monthly electricity bill is $\sim 20 \mathrm{RMB}$ per family $[\$ 2.50$ U.S./family/month]). 
From a regional-resource perspective, PV is viewed as the most reliable resource: customers buy sufficient PV to ensure that they have enough power, and may purchase a wind turbine depending upon financial resources. (During the course of a week, one could be certain of the solar input, but could go an entire week without a significant wind resource becoming available.)

Small diesel units cost approximately 5,000-6,000 RMB in Inner Mongolia. It is possible for herdsmen in remote locations to obtain diesel fuel from small towns in the region. Typically, the small town might be 50-60 km from their home; they would most likely drive there by tractor. The cost of diesel power varies from region to region, but generally runs between 1 and $2 \mathrm{RMB} / \mathrm{kWh}$. The fuel alone contributes approximately $0.5 \mathrm{RMB}$ to the cost per $\mathrm{kWh}$. By comparison, a grid-connected wind farm would supply electricity at $1 \mathrm{RMB}$ per $\mathrm{kWh}$. The typical herdsman customer is not focusing on the cost of power or the lifetime cost of an energy system; they simply want electricity and will tend to buy the cheapest. Wind maintenance is seen as being quite simple, and PV even simpler; the purchase price of PV, however, is quite high. The herdsmen do not use diesels because the quality of the generators is poor (poorer than that of either wind or PV), and it is difficult to provide the necessary maintenance in these regions. If a system does not work, the tendency is to throw it away and buy another.

The least reliable part of the renewables systems was judged to be the batteries. Typically, these are unsealed, lead-acid batteries that were designed for automotive use. (The maintenance on these batteries is considered to be poor.) Once again, the purchase price-rather than the term cost-is the feature that drives the purchase decision. The selection of a small battery (at a cheaper price) relative to the ideal needs of the system certainly accelerates the demise of the battery. During a subsequent visit to several remote hybrid installations, the system batteries were in need of replacing within a relatively short period, and the electronics had to be returned to the supplier in Hohhot (250-300 km from the herding area) within months of the initial installation.

\section{Ningbo Solar Electric Power Factory Ningbo, Zhejiang. 9/22/98}

The Ningbo PV production plant produced approximately $580 \mathrm{~kW}$ last year and was producing at the same level this current year (1998). The plant produces four types of modules using three different cell sizes $(4,3$, and 2 inches in diameter). The power ranges of the modules are 38-40 W, 18-22 W, 11-13 $\mathrm{W}$, and $8-9 \mathrm{~W}$. Their product is guaranteed for 10 years and they have been in production for about 12 years.

The Ningbo business, which is state owned, currently employs 105 people. Typical selling prices for their modules are about $40 \mathrm{RMB}$ per $\mathrm{W}_{\mathrm{p}}\left(\sim \$ 5 / \mathrm{W}_{\mathrm{p}}\right)$; however, the smaller modules are approximately $5 \%-10 \%$ higher in price. The company makes controllers as well as modules, and sells both modules and systems, mainly via 20-30 distributors in the northwestern provinces. Some product (particularly the smaller modules) is exported to the Middle East and Africa and neighboring countries around China. Larger modules are more typically used in aid programs (such as the Zimbabwe project), because the larger modules are their least competitive product. The $40-\mathrm{W}$ modules use 38 cells to achieve an open-circuit voltage of about 16.5 volts. The principal markets for these modules in China are Xinjiang, Qinghai, Gansu, and Inner Mongolia, as well as Tibet.

In addition to the standard products, Ningbo has exported a total of over 300,000 solar hats. The below20 -watt module range is the biggest seller in China, as well as systems of over 80 watts used for powering TVs. Many of the sales to the distributors are made on partial credit terms; apparently, it is often difficult to collect the full payments. The Ningbo factory claims to have approximately a $40 \%$ 
share in the China market and to be the biggest manufacturer. Their sales of controllers are not extensive, with typical annual sales of only 30 units.

\section{Pinggu County 100 Counties Program Pinggu, Beijing. 10/13/98}

Pinggu County was selected by the Ministry of Agriculture as a suitable site (not too far from Beijing) to view firsthand the progress being made on the major 100 Counties Program. Although the program does not have any PV component - it focuses to a greater extent on more efficient uses of conventional power, solar thermal, and biomass - this visit offered a valuable insight into the way in which the many overlapping central and regional government organizations can cooperate and set out to achieve a common project goal.

Located approximately $100 \mathrm{~km}$ from Beijing, Pinggu County has a population of 390,000 with a land area of 1,075 square kilometers, of which two-thirds are occupied by mountains. The average annual income in the agricultural sector of the county is 2,600 RMB ( $\$ 325$ U.S.); the urban income is approximately twice this level at $\sim 5,000$ RMB ( $\$ 650$ U.S.). By the end of 1995 , the energy gap in the county was 142,000 tons of coal equivalent. Pinggu County subsequently elected to participate in the 100 Counties Program because they recognized that energy is the basis of all development and they are keen to accelerate development in their region. Initially, the county set out to

1. Promote production and improve the living standard of the people.

2. Set up a leading group and allocate the responsibility of chief of the energy project to a particular individual.

3. Start from the easier tasks first, then progress gradually to the more difficult tasks.

There are 10 major projects in the Pinggu 100 Counties Program; these major tasks can be further divided into 23 subtasks. Details for 10 of these subtasks are provided below.

\section{Biogas and Ecosystem Project}

Install 200 biogas digesters in 200 households per year, in areas where the economy is not well developed (such as the mountainous regions). Plan 3,200 sites and assemble dedicated greenhouse biogas digesters to improve vegetable production and chicken breeding. The benefit to the farmer is in increased production efficiency per unit of land. The unit of Chinese land known as an MU is 666 square meters. At the start of a project, a typical MU could provide an income of $8,000-10,000$ RMB. After the completion of the project, production increased to $15,000-16,000 \mathrm{RMB}$ per MU, a significant improvement in output.

\section{Big Projects-Anaerobic Digesters}

This task focuses on the improved utilization rate of household digesters to $75 \%$ from the previous level of $40 \%-50 \%$ (as measured earlier) and commercial utilization of waste materials from digesters in breeding farms (pigs and chickens) for the production of liquid fertilizer for flowers. The solid waste can also be used to produce high-efficiency fertilizers for the land.

Later in the site visit, an inspection of a waste material collector for a large pig farm was performed. Also inspected was the downstream processing equipment for the commercial production of foilpackaged, odor-free liquid fertilizer for flower growers. 


\section{Sunshine Project}

This project has several elements, including solar water heater production and installation, passive solar houses, solar houses for pigs and chickens, and solar greenhouses.

\section{Integrated Construction in the Mountainous Areas}

This project seeks to integrate the construction of roads and irrigation systems to improve accessibility and improve the land for crop production in the mountainous regions. The condition of the land in these areas needs to be improved to permit the growth of fruit trees and other appropriate crops. After harvest, the improved roads are essential for getting the crops to market.

\section{Energy Conservation Project}

This project covers the research, production, and promotion of energy-efficient cook stoves for rural households. Several examples of the improved stoves were on display during the visit.

\section{Water Conservation Project in Rural Areas}

The project aims to improve irrigation and the utilization of water in industrial enterprises by reusing or recycling the water.

\section{Coal Conservation Project}

This project is being implemented in three sectors: improving coal utilization in the brick-making industry; improving the general use of coal products, such as the incorporation of coal dust into briquettes and the replacement of coal-fired boilers with solar energy facilities; and introducing new building materials to keep energy costs down.

As noted during the subsequent tour, one of the buildings had an additional glass wall incorporated into the construction of one face of the apartment complex. This resulted in suitable channeling to circulate the trapped solar-heated air to maximize the overall heating benefit to the building. Apparently, the overall construction cost was modest and the energy savings significant.

\section{Electric Power Conservation}

This project focused on improving the transformers in the supply system (because many of them were installed 20-30 years ago), reducing losses in the rural distribution system, and conserving power consumption in the cement factory. All three of these elements have now been completed.

\section{Oil (Petrol) Conservation in Agriculture}

Where possible, the various tasks involved in breeding, cultivation, and fertilization that use oil have been combined to reduce the number of tractor trips.

\section{Environmental Protection}

Full utilization of sewage (biogas project) is still at the demonstration phase. The production of energyconserving building materials, which are both energy efficient and more environmentally friendly, is an additional aim of the project. 
Among the 23 sub-projects, 20 have been completed and 17 have shown a real profit. The total profit from the project is currently 110 million RMB/annum (\$13.75 million U.S.). In addition, the energy supply has been increased by 145,000 tons of coal equivalent. Not only has the energy gap been filled, but the general energy usage has been reduced. The original gap of 142,000 tons of coal equivalent represented a $40 \%$ gap between supply and demand.

How much did the project cost and who paid? The overall project cost was said to be 200 million RMB per annum for five years, of which $8 \%-10 \%$ came from the central government, $17 \%$ in the form of a bank loan, and the remaining $75 \%$ from the local government and the local villagers and farmers. The loan was mostly from the Agricultural Development Bank. Regarding interest rates and the periods of the loans, it was said to vary by project and that some loans came from the local credit union. Typically, the loan period was between one and three years, although some loans are for longer periods and at low interest rates. Pure business loans are at $>10 \%$ and general loans are at rates between $7 \%$ and $9 \%$, while government loans can be as low as 3.5\%. All the projects in Pinggu are set to be completed by the year 2000 .

Overall, the number of improved cook stoves installed over the last 10 years has reached 100,000 units. (There are approximately 110,000 rural households in the county.) This amounts to a $92 \%$ penetration rate. Approximately 4,000 of the newer-design stoves have been installed. The stoves used to be $10 \%$ efficient; they have now been improved to better than $20 \%$ efficiency.

"The Leadership Group" was developed to manage this program. It has members from 17 different departments, including the SPC, STC, the Bureau of Finance, and the Agriculture and TVE Commissions. All of these members are under the leadership of the director general, who is the group chief. The group has three annual meetings: early in the year, the first meeting focuses on allocating the various tasks for the year; a second meeting at the six-month point makes any necessary course corrections; and finally, at the end of the year, a third meeting is held to assess the achievements for the year.

The 17 members of the leadership group are divided into four big groups, which are led by the Agriculture Commission, the TVE Commission, the local SPC, and the local SETC. Every three months, a project meeting is held in the local project office, and the 23 projects that are each allocated to one of the four project groups are assessed at that time.

The 100,000 improved cook stoves saved about 50,000 tons of fuel wood each year. The payback period of the project as a whole was approximately two years. After the current project is completed in the year 2000, the leadership group will probably continue this type of work and enlarge the focus somewhat. This type of collaborative approach can provide real tangible benefits; as such, it would seem valuable to retain the leadership structure.

The 100 Counties Program started in 1980; in 1995, the second batch of counties programs was launched. It was thought that, by the year 2000, the successful project modules would be developed based on the experiences to date, and that the "lessons learned" would be packaged for distribution to the remaining counties in China. There are 2,400 counties in China.

\section{Qinghai Provincial New Energy Research Institute Xining, Qinghai. 9/8/98}

It became apparent around 1988 that potential customers of the institute, which started in 1983 essentially as a PV research organization, would like to be able to purchase products developed by the institute. Between 1988 and 1992 the institute assembled some 1,250 systems, with a total wattage of 
$22.9 \mathrm{~kW}$, for sale. With market demand increasing, the institute found it more appropriate to set up a separate PV company to manufacture and sell PV products. In 1992 the first company was formed to provide this commercial outlet. In 1993 and 1994, this company produced and sold 3,250 PV systems with a total capacity of $61 \mathrm{~kW}$. In 1995, with changes in the corporate laws in China, it was found necessary to increase the financial base of the company; the institute was then made one of the new company's shareholders. Thus, the Qinghai Provincial Solar Electric Power Company, Ltd. was born. Since 1995, Qinghai Provincial has produced more than 16,000 systems totaling about $245 \mathrm{~kW}$. Over a 10-year period, more than 21,000 systems with a total wattage of $326.9 \mathrm{~kW}$ were produced. Also in 1995, the company started to target markets outside of the province of Qinghai, and has now reached a point where more of its production is sold to other provinces/autonomous regions such as Gansu, Xinjiang, and Inner Mongolia, as well as Tibet. The institute is still judged to be the biggest PV provider for the province of Qinghai. By the end of 1997, about 40,000 PV systems had been sold in Qinghai by all manufacturers (including the institute). From 1995 onwards, other firms within the province started producing PV systems, and companies outside of the province began shipping product into Qinghai. Most of the systems are boxed (metal or wood), portable SHSs. Starting at 50 watts, the systems go down to 20 and 10 watts.

Given the purchasing power of the typical rural customer, the fact that they live in scattered locations, are frequently illiterate, and that, in addition, they are minorities with their own different lifestyles, they tend to resist new things. The institute sends some products free of charge to help the markets evaluate the systems. They also advertise via radio and TV and in magazines. In addition, minority salesmen have been hired to provide an effective interface with the target customer groups. They have established 38 sales offices to date, both within and outside the province of Qinghai. Typically, these offices also offer maintenance service to the customers.

Between 1986 and 1997, 3,000 wind turbine sets were sold in Qinghai province. Although the turbines were designed by the institute, they were manufactured by another company that was subsequently responsible for the after-sales service. Ultimately, this company found it financially impossible to continue to provide service to the very remote, isolated turbine customers. Today, with the increase in customer energy demand, they produce PV-wind hybrids for wealthy customer groups (for powering TVs or video recorders). In addition, they also supply PV power stations; they have sold seven such systems to date. In some instances, they cooperate with other companies in installing such systems. The smallest system is $450 \mathrm{~W}$ and the largest is $7 \mathrm{~kW}$. Payment for such systems comes from a variety of sources, including grants from the Chinese Government or international agencies, the Qinghai provincial government, and money collected by village communities.

An example of an international agency project would be the 4-kW system funded by the United Nations Development Programme (UNDP) for the Qinghai lake region. The system was installed in 1993 and supplies about 50 houses with electricity for 3-4 hours daily when there is little or no cloud cover. In Qinghai, about 5 million people have no electricity. There are 89 unelectrified towns, 781 unelectrified villages, and approximately 1 million people with partial electricity.

The approximate total potential for PV electrification in Qinghai Province is 200,000 systems. The main barriers identified by the institute included difficulty in getting information on new developments in renewable energy technologies. However, the institute plans to collaborate on a Finnish aid project for a 7-kW for village power station, and is also aware of the Solarex modules that were part of the UNDP project. The institute also has experience with Neste solar lanterns, which are apparently favored by the rural villagers.

Qinghai Provincial has about 34 employees excluding the salespeople. There are three different types of sales outlets: 
1. Totally company owned: the company rents the store, and pays the salaries and other fees.

2. Independent businessmen who sell on commission.

3. Existing shops or businesses that act as sales outlets - they buy the product and sell it at a higher price.

The total sales of the institute's company last year were approximately 10 million RMB, with some small profit. Typically, they expect to see a $25 \%$ annual increase in sales; however, they are now forecasting no increase due to financial constraints. As for any further investment in the company, this decision rests solely with the chairman, who provided this briefing.

\section{Qinhuangdao Hua-Mei Photovoltaic Electronic Company, Ltd. Qinhuangdao, Hebei. 9/29/98}

This module manufacturer, which began operations in 1985, is owned by a combination of two provincial government bodies. The enterprise has 200 employees and an annual output of $350 \mathrm{~kW}$. Most of the major production equipment was acquired from the United States in 1990. Having recently increased its crystal- growing capacity with the addition of a second puller, the company now believes that its wafer line is capable of producing $500-600 \mathrm{~kW}$ per annum. Each puller is said to be able to accept a $30-\mathrm{kg}$ charge and produce material with a diameter of up to 6 inches; however, at present, the standard production is based on 4-inch-diameter material. The cell and module production lines are said to be capable of producing $1 \mathrm{MW}$ per annum, with sales of approximately 20 million RMB. From an equipment and module production standpoint, this company is certainly a leading PV facility within China.

From an international perspective, the company has also attracted the interest of major PV manufacturers from both Europe and the United States; representatives of both camps have visited their plant within the last few months. In addition to PV firms, they have also had visits from investment banks looking to discuss cooperative ventures. The various international visitors have apparently also done the rounds of the Ningbo and Yunnan plants.

The company's business this year (1998) is up by $20 \%-30 \%$ over last year. And given the optimism regarding the availability of improved cash flow, they expect to be able to accept more export business in the coming year, thus increasing their sales to the $500-\mathrm{kW}$ level. The limiting factor at present is cash flow, which has forced the company to turn down export opportunities such as a South African contract that would have paid via a letter of credit. In all, the company estimates that it had to refuse approximately $300 \mathrm{~kW}$ of business during the past year due to lack of cash flow. Typically, the company requires part payment (40\%) with any order for most of the business that they accept; the remaining $60 \%$ of the payment is received upon delivery. Credit terms are only given to certain provincial organizations. Profit on sales is about $10 \%$, and the cost of money - if they could borrow - would be 6\%. Payment for materials is made upon delivery or, in some extreme cases, within 1-2 months. Production labor costs approximately 10,000 RMB per annum and the various benefits add approximately $25 \%$ to this salary cost. Supervisory workers receive approximately a $40 \%$ premium. Apparently, there are no restrictions on shift working for either male of female staff. Wages are paid on the 10th of every month.

A new provincial government incentive instituted in September 1998 will improve the company's cash flow situation, allowing them to essentially discount letters of credit. This will provide sufficient funds to permit the purchase of essential materials to allow the ordered product to be manufactured. Given the local pressure to increase profitable activity (including the mayor calling for even higher increases 
in sales in a recent local review), freeing up this business to accept valid, valuable export orders would seem to be high on the list of options for expansion.

Sales are divided as follows: telecom, $50 \%$, SHS $20 \%$, and village power $30 \%$. A sizeable telecom installation would be $70 \mathrm{~kW}$; in fact, the company has recently supplied the modules for a LanzhouTibet communications system. Typically, the company supplies the modules to system integrators such as Jike Company of Beijing for such jobs, or they supply directly to the relevant telecom organization. On the other hand, Qinhuangdao Hua-Mei PV Electronic tries to avoid the SHS market in general, because the average price is low and the majority of the distributors are unable to meet their special payment requirements. Although a module manufacturer sells its product to the SHS market based on $\mathrm{W}_{\mathrm{p}}$, apparently many of the small distributors subsequently sell on a module-area basis. (Bigger is perceived as better; and, therefore, bigger commands a higher price?) This company does supply some product to the SHS market through regional municipal government organizations. If the World Bank program provides some financial support to the SHS distributors and clears up the module-area/wattage practice, then sales to this segment might become more attractive.

The pricing of sales is said to be the same for both export and domestic markets, with the only advantage from exports coming from duty claw-back on the imported materials that are subsequently exported. Currently, module glass and Tedlar are imported. Small modules typically cost about 10\% more to produce than large modules due to the added materials costs and the increased labor per $\mathrm{W}_{\mathrm{p}}$.

Although the company has had modules working reliably in the field for up to eight years, in general they do not offer any guarantee of module life. However, the company does make free exchanges of modules when failures are brought to their attention within the first five years. Apparently there is no stringent telecom specification that requires some specific module reliability or lifetime guarantee. Modules are sold at $\sim \$ 5$ per $\mathrm{W}_{\mathrm{p}}$, a price level that has not changed in recent years. Electricity costs $0.58 \mathrm{RMB}$ per $\mathrm{kWh}$, which is similar to costs in Beijing. They estimate that they supply approximately $40 \%$ of the domestic PV market, excluding imported modules, amounting to approximately 200-300 $\mathrm{kW}_{\mathrm{p}}$ per annum.

\section{Shenzhen Nenglian Electronics Company, Ltd. Shenzhen, Guangdong. 9/23/98}

This private company was established in its current form last year (1997). The various staff members, however, have a great deal of prior PV module and systems experience spanning over 10 years. Mostly, this experience has been in the form of installation of professional PV systems such as microwave repeater station power units. The various installations that the team has successfully undertaken were detailed during the visit. Typical repeater power unit sizes are about 6-8 $\mathrm{kW}$ and the systems list provided included at least 50 microwave power units. The Shenzhen team has also undertaken village power projects and fiber-optic link power systems; in addition, it has sold about $400 \mathrm{~kW}$ of SHS in the 10-20-W range. The Shenzhen-based company, which has three stockholders and a staff of eight, essentially operates as a commercial/marketing unit collaboration with a module assembly unit in Hubei, which carries out contract module assembly on behalf of Shenzhen Nenglian Electronics. The Shenzhen staff specify the modules and set the quality standards, which appear to be the highest in China. The company has the small modules built in China using largely imported components, including Siemens cells. The larger modules are imported completely assembled from Siemens. Capturing approximately $20 \%-25 \%$ of the annual market in China, they sell about $300 \mathrm{~kW}$ per annum. Sales last year reached 11 million RMB; however; they expect the sales this year to be somewhat lower ( 8 million RMB) due to the poorer economy in China. 
The 20-W SHS modules are produced in China. The forecast for the near future suggests that the wattage for SHSs will tend to be reduced, reflecting the degraded financial circumstances of the typical rural customer. In addition to modules, this company also specifies and has built charge regulators and inverters. They also installed a grid interactive system in $1996(114 \mathrm{~kW})$, which was supported by the Dutch government. The inverter supplied from Germany operates with a PV rail voltage of $400 \mathrm{~V}$.

From a cost and pricing standpoint, the imported components and modules lead to a selling price that is typically $15 \%$ higher than the indigenously produced modules. In the case of SHS, this company has tried to sell complete systems rather than modules; however, the distributors insist on making their own electronics to achieve lower-priced systems. It is currently hoped that the World Bank program will begin to set standards, and that those standards will eventually be enforced, thereby improving the quality of the rural SHS offering.

Unlike most of the other companies that were asked to identify the biggest challenge to the advancement of PV in China, this company identified the lack of clear government agency leadership as the main problem.

\section{Shenzhen - YK Solar Energy Company, Ltd. Shenzhen, Guangdong. 9/23/98}

In 1988, negotiations began to establish this joint venture a-Si plant in Shenzhen. Equipment from Chronar, Inc., a U.S. firm, was eventually installed in 1991. The joint venture was initially established between the Yukong Company, Chronar, the World Bank, and the Shenzhen development group, none of which are state owned. Following the demise of Chronar (after the joint venture was under way), the support for technology updates ended, as did maintenance assistance from the U.S. partner.

Currently, the plant is operating at a reduced level of throughput due to a lack of both markets and replacement spare parts. The tin oxide furnace was in operation and reasonable-quality tin oxide layers were being produced. There was some streakiness in the tin oxide layers, which affected the visual appearance of the finished panels and proved unacceptable to the calculator market (which the company also wanted to service). The second tin oxide furnace was not in operation, as parts for one system had been cannibalized to keep the other furnace operational. Similarly, only one of the two laser scribers was operational, due again to lack of replacement parts. The same laser was being used to scribe both the tin oxide layer and the amorphous silicon. The final metalization layer was being evaporated with a shadow mask, thus avoiding the need for a third laser-scribing process. Apparently, the company's relationship with their spare parts supplier was not proving effective in obtaining the necessary spare parts. The plate and module test station in the production line was undergoing adjustment during the visit; therefore, it was not possible to confirm the current standard of production as regards efficiency and fill factor. The plant was said to be producing at the rate of 30,000 watts per month during the last three months.

The 3-foot by 1-foot panels, with a film encapsulation, are sold at a price of $25 \mathrm{RMB}$ per watt $(\sim \$ 3.125 / \mathrm{W})$, and the main markets for the product are in Africa. The product, which is sold with a five-year guarantee, has an initial wattage $20 \%$ above the guaranteed value. In addition to the film encapsulation, the edges of the plates are further protected by a rubber-edge strip, which fits between the aluminum frame and the glass sheets.

In addition to the plant's technical problems, the company will be further hampered in the Chinese market by the decision taken in connection with the World Bank program to exclude a-Si from the list of acceptable PV module technologies. Given the type of application and size of module required for many of the Chinese rural markets, a thin-film approach would appear to be the best technoeconomic 
choice. Smaller-wattage modules can be made much more cost effectively using thin film as compared with the task of assembling many parts of cells of crystalline material to achieve the same wattage. Thus, it would seem to be more appropriate to set module performance requirements to be met by any reliable PV technology, not to have preselected crystalline silicon as the only choice. It is apparent that China's a-Si program has significant challenges to overcome before it can meet international quality standards. There are thin films produced in the United States, however, which could certainly be applied to this program in order to achieve the best costing/pricing levels, which in turn should make the SHS more acceptable to a wider section of the rural population. Similarly, such an approach would give an incentive to Chinese thin-film plants to improve their technologies to meet the required performance standards to service this important market within China.

From previous meetings in China, it had been learned that an additional a-Si processing technology had recently been transferred to the Shenzhen plant to enable them to produce product suited to the solar calculator market. Neither this style of product nor any thin-glass process was seen during the plant visit.

The plant currently employs about 60 people. However, its financial resources are limited; the utility bill alone amounts to about $100,000 \mathrm{RMB}$ per month $(1.1 \mathrm{RMB} / \mathrm{kWh})$. This electricity tariff is approximately twice the rate in Beijing.

\section{Sinosolar Industry Company, Ltd. Shenzhen, Guangdong. 9/24/98}

Established in 1993 with five stockholders, all of whom are state owned, the Sinosolar Industry Company, Ltd. designs and produces submersible pumps, dc compact lights, and solar power supplies and inverters. Several pumps were observed in operation during the visit; Sinosolar has had pumps operating in the field for about 25 years. Typically, the $250-\mathrm{W}$ pump sells for 3,000 RMB $(\sim 375)$. The pumps resemble the Grunfos style of submersible pump. The pumps, de lights, and various controllers and inverters appear to be of good quality; total sales are approximately 60 million RMB ( $\$ 7.5$ million) per annum.

Sinosolar has a 2-kW, roof-mounted solar array on its building that uses Yunnan Semiconductor modules, each of which is designed to be 35 watts in capacity. The modules, which have been mounted on the roof for about five years in a fairly corrosive environment, seem to be surviving well. The array provides power for the various demonstration systems in their building, such as the pumps in the test laboratory.

The main market segments that this company serves include PV pumps, SHSs, and power systems. These systems are all stand-alone; the company does not have grid-connected experience. The total wattage of systems sold in the last year (1997) was $6 \mathrm{~kW}$. In general, they did not provide many modules, but rather the pumps, for inclusion in other peoples' PV systems. In addition to the 10 people working at Shenzhen, the company employs 80 people in its various other business locations, including Beijing, Shanghai, and Hong Kong.

All of the technology that the company uses is said to be of its own design; for example, although the PV pumps were developed with the help of a university, Sinosolar has made significant R\&D improvements on the basic design since its inception in 1995. They estimate that their share of the PV pump market in China is nearly $100 \%$, and that most of the pumps being supplied are for demonstration (rather than truly commercial) projects. 
The main challenge to this well-managed, quality company, however, is the current size of the China market. Sinosolar has researched the water table depths in the various northwestern provinces, including Qinghai, Gansu, and Inner Mongolia, as well as Tibet; unfortunately, however, the amount of provincial money available to fund the installation of pumps such as Sinosolar's in these needy regions is very limited indeed. Sinosolar estimated that there are thousands of small distributors in the northwestern provinces (such as Gansu, Qinghai, and Inner Mongolia, as well as Tibet) who are providing poor-quality systems at low prices. The Sinosolar lights are purchased by only about 20 of the northwestern distributors, with the rest building their own circuits of possibly dubious quality. There is hope that the World Bank program might improve this component and system quality problem. The company also anticipates that the market mechanisms are gradually improving in China, which should ultimately lead to pressure for improved quality.

In 1997, Sinosolar sold 300 lights, increasing to 5,000 units in 1998. The 4-5-W lights, if purchased in 100-unit quantities, would be priced at $30 \mathrm{RMB}$, and the tube alone would be priced at $10 \mathrm{RMB}$. Sinosolar expects to expand its business by $\sim 50 \%$ per annum over the next few years, driven largely by additional sales of de lights, for which it has ample production capacity. In addition to expanding the dc light sales, Sinosolar expects to expand its PV pump offerings. There were clear signs of export activity to Europe (including Holland, among other locations) during the visit.

\section{Solar Power Development Center for Xining, Qinghai Xining, Qinghai. 9/10/98}

Established in 1995, this is a private stock company with 42 employees and annual sales last year of nearly 6 million RMB. Their main products are 4-, 10- and 20-W SHSs. They sell a total of about 5,000 systems per annum, with $40 \%$ sold inside the province and $60 \%$ outside. In addition to sales to neighboring provinces, they also make some export sales (including Nepal). A 4-W system sells for approximately $100 \mathrm{RMB} / \mathrm{W}(\sim \$ 12.5 / \mathrm{W})$. Such a system would have a $4-\mathrm{W}$ module and one 9-W tube. The company buys their modules, approximately 5,000 per year, from the full range of indigenous suppliers. The modules arrive in Xining via train. Sales are made on a cash basis; no credit is involved.

The company does not make use of other companies' designs under license. It has two plans for next year's (1999) sales. In addition to making sales through their existing outlets, they want to set up new outlets in regions that are currently without representation. They want to begin to differentiate their product to avoid head-on price competition; it was noted that the competition in the Xining area was generally very fierce.

The least-reliable system component was judged to be the battery, which the company typically buys from Wuhan Company in Hubei Province. The Solar Energy Power Development Center makes their own circuits for controllers and dc light supplies. Maintenance of systems is provided by any of their sales outlets free of charge within one year of system supply. The sales outlet gets reimbursed for this maintenance; they do not eat into their sales margin to cover maintenance.

The main problem for the business is not finances, but rather the need to differentiate themselves in the marketplace. They would be interested in working with hybrids, but have not as yet supplied any hybrid systems. The current sales outlets sell a range of technical products such as tractor parts and butter separators; therefore, in general, they are comfortable with technical product.

\section{World Bank Project Discussions}

Beijing. 10/4/98 
Having gained a reasonable understanding of the status of the main distributors in northwestern China, and having begun to understand the proposed approach planned for the Global Environment Facility (GEF)/World Bank PV program in China, it was interesting to compare notes with a World Bank expert from Washington, D.C. It was generally agreed that the major reliability problem associated with the many tens of thousands of small SHSs shipped by the distributors throughout the northwestern provinces was the homemade electronics (both the controllers and the de lighting circuits). Although plans had been drawn up to establish a system to qualify the system components that could be used in the GEF program, a list of specific test houses to be used in China had yet to be decided upon. It was also agreed that it would be valuable if the quality lighting units that are manufactured in the larger semiautomated factories (such as the unit in Gansu), could somehow become widely adopted by the small-system integrators, replacing their homemade units (which are probably of doubtful reliability). No clear process for encouraging the approach could be immediately identified; it was agreed that future discussions were necessary.

In addition to discussing the technical program challenges, questions were asked regarding possible suitable communications routes for informing the U.S. and European PV communities of the upcoming GEF/World Bank briefing to be held in China.

\section{Yunnan Normal University/Solar Energy Research Institute (SERI) Kunming, Yunnan. 9/28/98}

Yunnan Normal University has been conducting research and development on PV for more than 20 years. It transferred the original technology to the Yunnan Semiconductor Devices Factory. In the near future, Yunnan Normal will assist the factory in acquiring polycrystalline casting equipment to enhance their production capacity and reduce overall costs. In addition to working on crystalline and polycrystalline silicon, Yunnan Normal/SERI also works on copper indium diselenide (CIS), gallium arsenide, and cadmium telluride. The cells are typically $1 \mathrm{~cm}$ square, whereas the substrates are $2 \times 4$ $\mathrm{cm}$. The R\&D team consists of nine researchers plus some postdoctoral students working under funding from the provincial ministry of science and technology. In the early 1980s, they did research on such systems as TV relay stations, traffic systems, and household SHSs. Work has also been performed on hybrid systems (150-W wind, 300-W grid power, and 100-W PV).

In addition to proposing work on hybrid PV-hydropower systems within Yunnan, where the main grid power source is hydro-based, the institute also shared its ideas on the possible combination of the Yunnan Semiconductor Devices Factory, the institute, and the Rural Energy Working Stations that are part of the municipal resources in the province. This combination may well offer the basis for an effective rural PV SHS deployment vehicle. Given the close working relationship between the university and the Semiconductor Devices Factory and their close support from the provincial government, this may be an effective way to begin to recognize PV SHSs as a cost-effective route to basic rural electrification. The experience in South Africa regarding the cost-effectiveness of grid extension and SHS for remote home electrification was discussed briefly, and a commitment was made to provide copies of the various papers on the topic to assist Yunnan Normal University in bringing the provincial government up to speed on the acceptance of PV as a cost-effective and reliable rural electrification technology.

The energy picture in Yunnan Province is particularly interesting because the main power source for electricity is hydro (70\%); however, the availability of the hydro resource is somewhat seasonal. Even in regions where grid electricity is available, there may well be an argument to supplement the grid to offset the periodic reduction in hydro-based power. 
Professor Liu Zuming, of the institute, is the key person involved in developing the national PV module standards in China.

\section{Yunnan Semiconductor Devices Factory Kunming, Yunnan. 9/27/98}

Yunnan Semiconductor was set up approximately 21 years ago to produce single-crystal solar cells. This provincial administration business originally entered the PV field looking for a profitable outlet for silicon at a time when the use of its silicon wafers in semiconductor transistor production proved uncompetitive. In the mid-1980s, production equipment (of U.S. origin) was imported secondhand from Canada. With a design production capacity of $500 \mathrm{~kW}$ per annum, the company claims to be the largest solar cell manufacturer in China, satisfying some $40 \%$ of the larger-module business. The modules have an efficiency level of 14\%. Because of its close relations with Yunnan Normal University (located in Kunming) and various local government departments, as well as the SPC and the State Economic and Trade Commission, the company's technology improvements have been included in national government programs for the 8th and 9th five-year plans. With the planned addition of polysilicon production, they expect to reach a combined capacity (poly and single) of $1.5 \mathrm{MW}$ in the coming year (1999). They also expect single-crystal silicon to dominate for some time, but will add polysilicon to reduce costs and avoid shortages of material.

There are about 300 employees in the Kunming factory; they are said to produce over $400 \mathrm{~kW}$ per annum. Given their 20-plus years experience, they are also said to have good engineers and an excellent sales network. Although they are the largest solar PV manufacturer in China, they plan to increase their share in the coming years. They are also very keen to enter into a cooperative relationship with European or U.S. manufacturers to improve their technology and increase their capacity more rapidly, which should result in their jointly capturing larger markets. Their scale of production was at the 100$\mathrm{kW}$ level in the early 1990s; they have had product continuously operating in the field for about 15 years.

Last year (1997) total sales exceeded 20 million RMB, with a mix between modules and added-value systems of approximately 50/50. The typical module sells for between $\$ 5$ and $\$ 6 / \mathrm{W}_{\mathrm{p}}$. Typically, however, Yunnan Semiconductor tries to sell added-value systems rather than just the modules alone. The SHS modules of 20 watts or less make up less than $10 \%$ of their business.

Currently, Yunnan Semiconductor has four crystal pullers, one of which is of Chinese origin. These pullers produce a total of 700-800 kg of silicon per month. The eight ID saws cut the silicon into wafers of $\sim 400$ microns in thickness. The wafer and puller sections of the plant run on three shifts; the rest of the plant can produce at current levels with one shift in operation. Cells are sorted automatically into 10 different performance levels prior to being used in matched sets in module assembly. There was more automation on this production line than on any other seen during the entire visit to China. The lay-up of smaller modules was based on a printed layout card similar to the procedure seen frequently in India; however, the company's larger 40-W standard modules are laid up in a semiautomatic form. Unlike other manufacturers, Yunnan Semiconductor Devices claims that the production cost of its small modules is somewhat less than that of larger modules (in terms of $\$ / \mathrm{W}_{\mathrm{p}}$ ) because they elect to use less costly materials in these smaller products. The larger modules sell at 45 RMB per watt, whereas the smaller modules sell at a reduced price of 42 RMB per watt.

Yunnan Semiconductors' major market is in Tibet. They have installed plants in China at the 100-kW level. Three of their larger plants are said to be grid-connected in a hybrid fashion. Yunnan Semiconductor Devices did not supply the hybrid controller that interfaces between the grid, wind, and 
solar systems. The company does not make large inverters; instead, it has an agreement with Morningstar to produce smaller charge regulators. Their Gansu installations make use of the Morningstar controller and, to date, they have had good experience with the technology. There was a specific request for information on U.S. manufacturers of larger inverters and charge controllers. The contact details for Omnion and Trace were supplied, as was a directory of U.S. PV-related manufacturers.

Yunnan Semiconductor Devices Factory is seeking the following assistance for its business from international sources: 1) loans to accelerate technology improvements; 2) JVs to further improve its technology; 3) the capacity to provide service at an international level; and 4) training programs.

In forecasting the future trends of the China PV business, this company expects to see increases in the SHS market due to: 1) the World Bank assistance program; 2) generally improved income levels; and 3 ) the action of the various poverty alleviation programs, which can be expected to make an impact on the conditions of China's 70 million unelectrified people. At the local level within Yunnan, the company would like to see the electrification of the rural schools, of which there are several thousand. Each school would need $\sim 100$ watts at a cost of $\sim 20,000$ RMB. These systems would use dc power supplies for lighting and satellite TV.

\section{Zhongxing Electronics Instrument Factory Lanzhou, Gansu. 9/13/98}

This business has approximately 800 workers, of which 200 are technically qualified. At least $33 \%$ of the workers studied in university or college. The factory produces PV energy-saving lights and energysaving water heaters. About $60 \%$ factory income comes from the sale of the energy-efficient water heaters. They began their involvement with PV in 1992; they targeted lighting and communications, both in the electrified and the unelectrified regions.

The factory's total PV sales last year reached 4 million RMB, which was $10 \%$ of their total business. The compact-fluorescent-tube plant has the capacity to make 1 million tubes per annum. In the last year, after a technology change, approximately 100,000 compact fluorescent tubes and 6,000 electronic controllers were produced. (Their production capacity for electronic controllers for PV systems is about 30,000 sets per annum.) The electronics factory used to make military equipment, so their quality standard is still very high.

Most of Zhongxing Electronics' PV sales are in the province of Gansu. There are 28 towns without electricity and 2,800 unelectrified villages in the province. There are possibly three separate villages that make up one administrative village; therefore, the 2,800 figure may represent more than 8,000 recognizable villages.

Given the improving standard of living of the farmers, the 20-W systems should sell well; the price of the system is readily affordable. However, after touring the compact fluorescent-tube line and the unit making dc circuits for the lights, questions were posed as to why this line, which has excellent equipment, is only partially utilized, whereas most (if not all) individual solar distributors decide to make their own de lighting system rather than simply buying the tubes. Apparently, the answer in the past has been that their quality product (the electronics factory was once used to make military equipment), coupled with their relatively high overhead, makes the cost high by comparison with the small distributors' cost of making their own. 
The end-use customer may well suffer the consequences of the small distributors' cost cutting. Typically, the 4-10-W dc lights cost 18-20 RMB $(\sim 2.25-\$ 2.50)$ if purchased from this plant. Buying the tube alone costs approximately $7 \mathrm{RMB}$. According to the estimate, the small distributor probably can make their own unit using a purchased tube for a total of 15 RMB.

After considerable discussion of this apparently "sensitive issue," factory personnel volunteered that there was a plan to begin to offer their de light at a reduced price of 14 RMB. They also hoped that the World Bank program would be able to differentiate between quality lighting products and homemade units with possible quality problems. Considering the high-quality, well-controlled processes for producing both the lighting tubes and the control electronics, the China PV markets would be well served if these products were adopted by many of the small independent distributors, rather than continuing with the current practice (which would eventually kill the SHS market in the northwest provinces). 


\section{Photo Album}




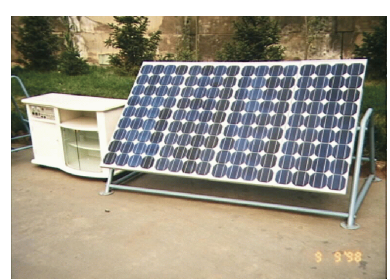

1. Xining - Distributor's Large PV Array

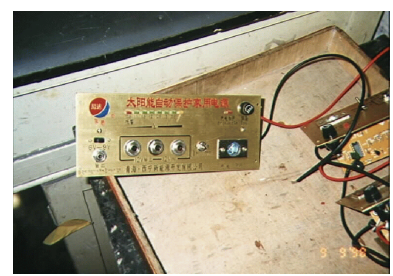

2. Xining - Typical SHS Controller Panel

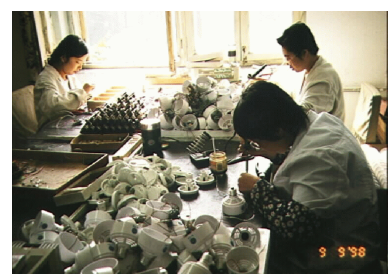

Force

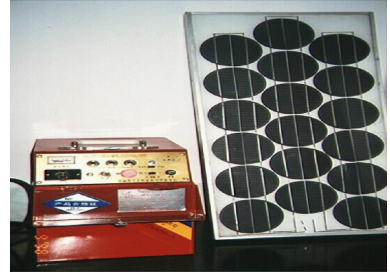

5. Xining - Full SHS

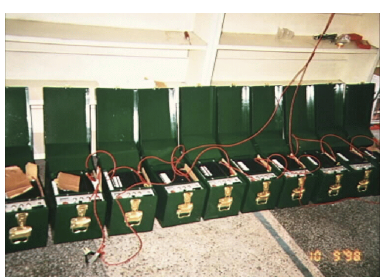

6. Xining - Batch of SHSs for Tibet

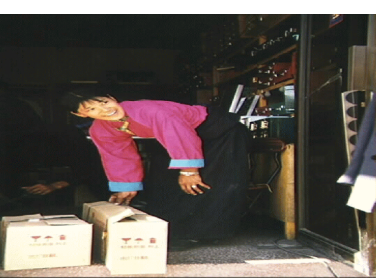

7. Xining - Tibetan Solar Shop

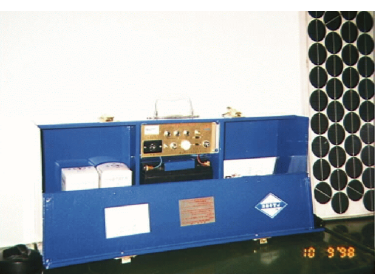

4. Xining - SHS Variant

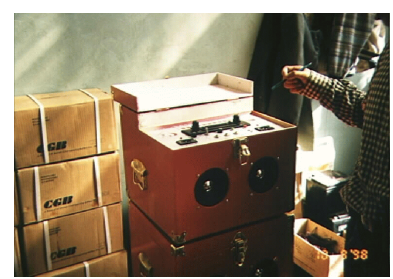

8. Xining - Distributor's SHS Product

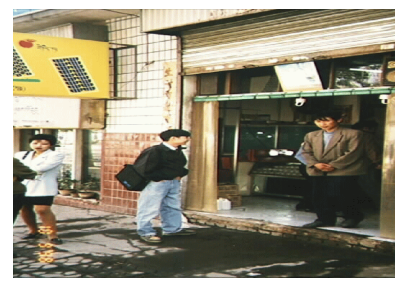

9. Xining - Solar Shops

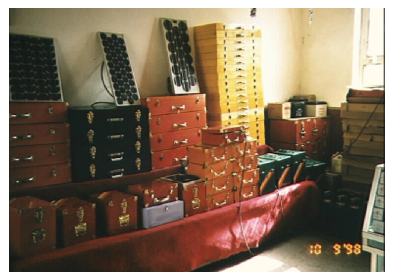

10. Xining - Solar Shop's Stock

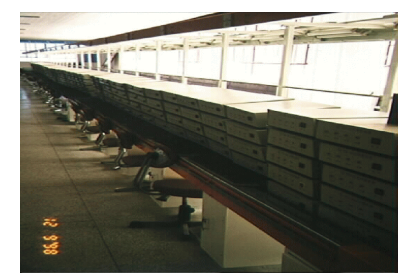

11. Lanzhou - Production Capacity

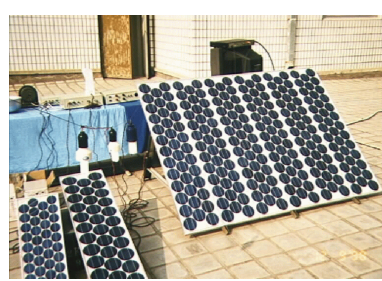

12. Lanzhou - Rooftop Demo

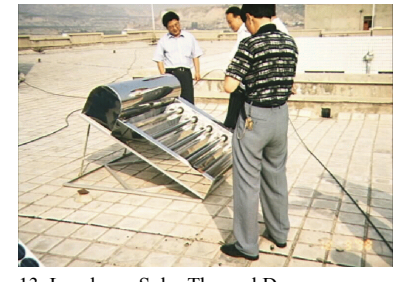

13. Lanzhou - Solar Thermal Demo

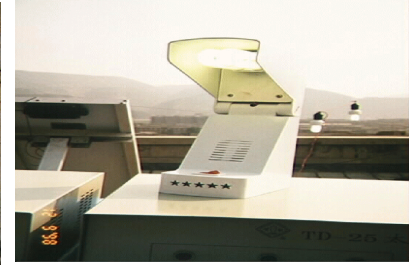

14. Lanzhou - Innovative Desk Lamp

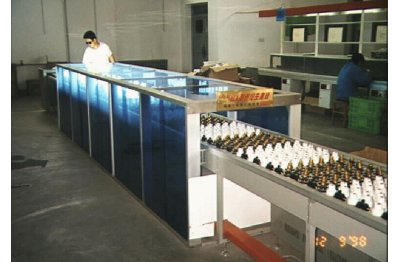

15. Lanzhou - Scale Production CFLs

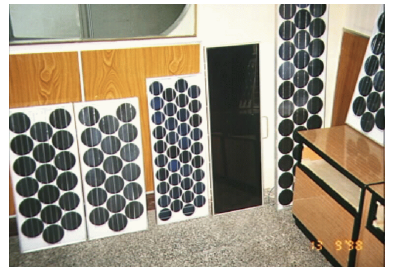

16. Lanzhou - Organization's Demo Room

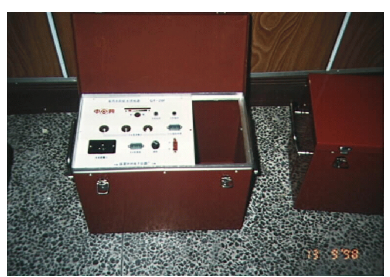

17. Lanzhou - SHS unit

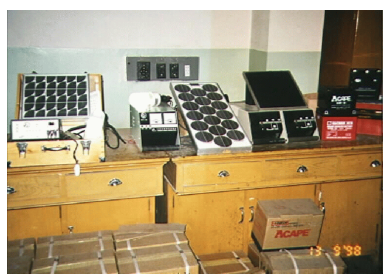

18. Lanzhou GNERI Lab

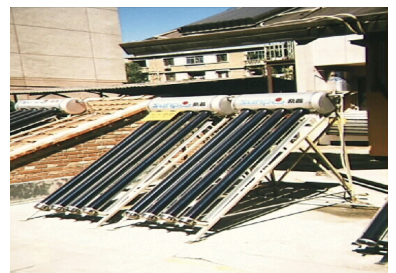

19. Beijing - Solar Thermal

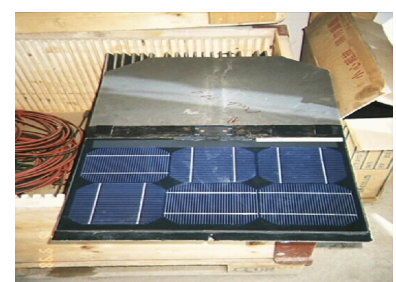

20. Beijing - PV Tile at BNBM 


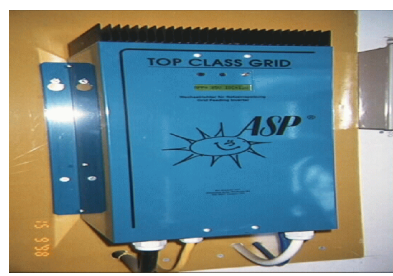

21, Beijing - Solar Roof's Inverter

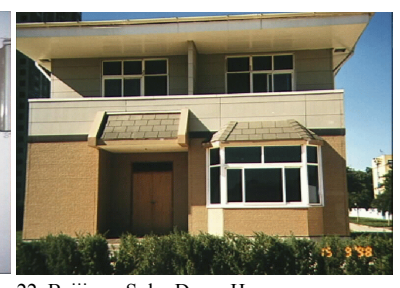

22. Beijing - Solar Demo House

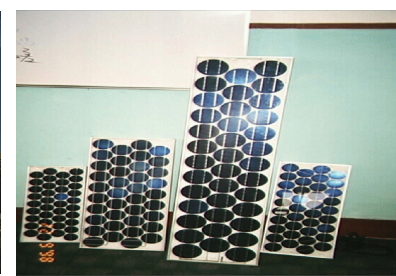

23. Ningbo - Module Range

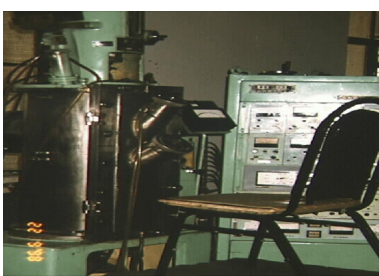

24. Ningbo - Pulle

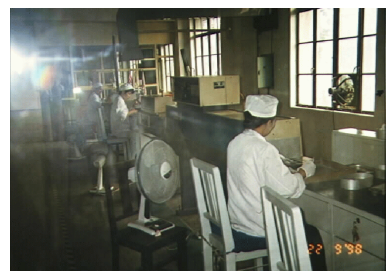

25. Ningbo - PV Production

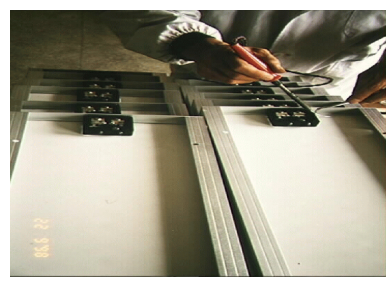

26. Ningbo - Module Final Assembly

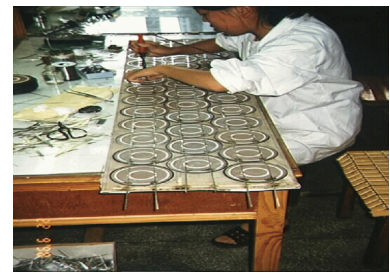

27. Ningbo - Cell Soldering

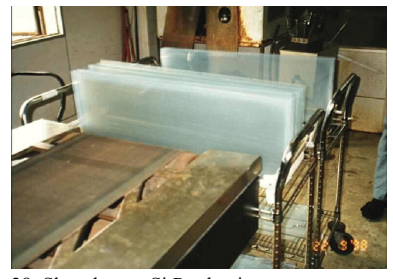

28. Shenzhen - aSi Production

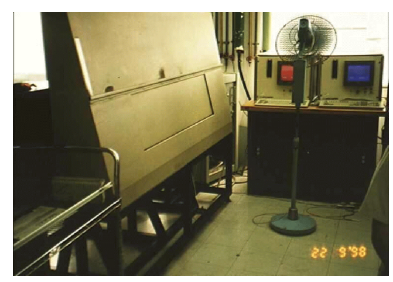

29. Shenzhen - aSi Laser Scriber

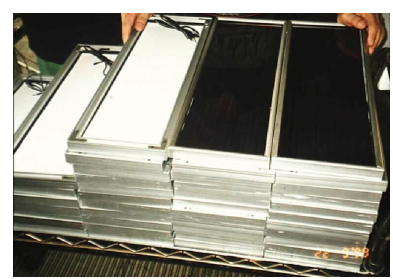

30. Shenzhen - aSi Finished Modules

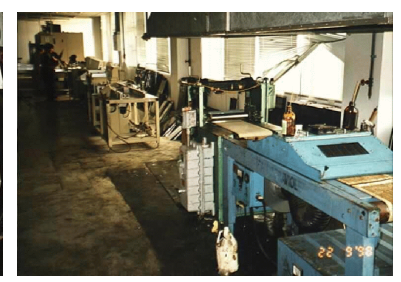

31. Shenzhen - aSi Module Line

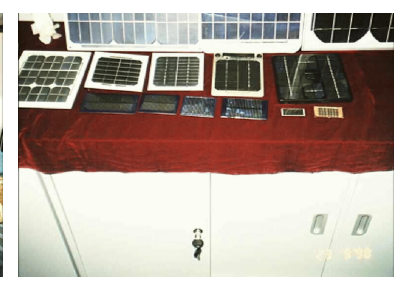

32. Shenzhen - PV Showroom
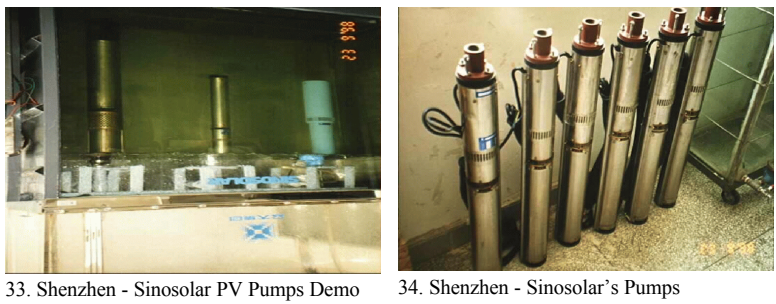

34. Shenzhen - Sinosolar's Pumps

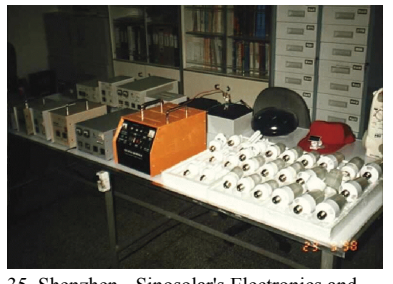

35. Shenzhen - Sinosolar's Electronics and

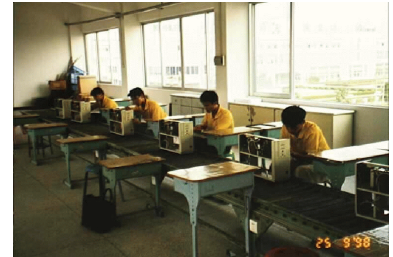

37. Foshan - HK Co's Production Line

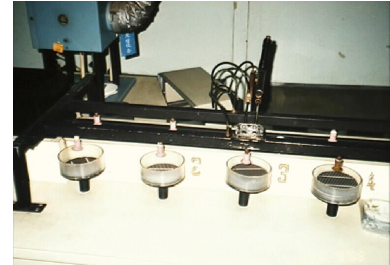

38. Kunming - Yunan SC Cell Sorter

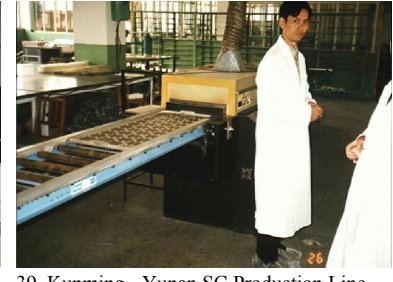

39. Kunming - Yunan SC Production Line
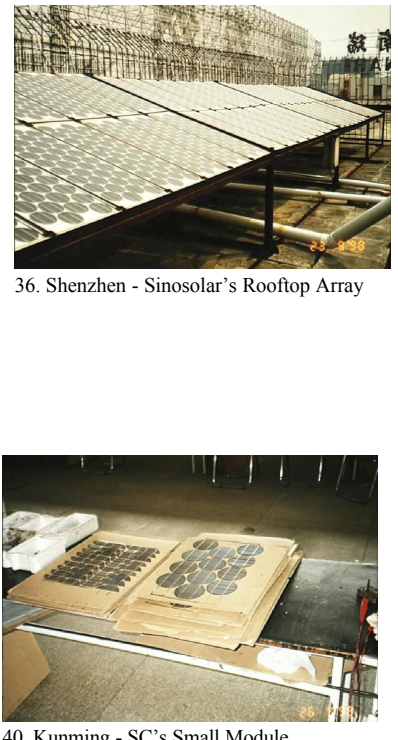

40. Kunming - SC's Small Module Assembly 

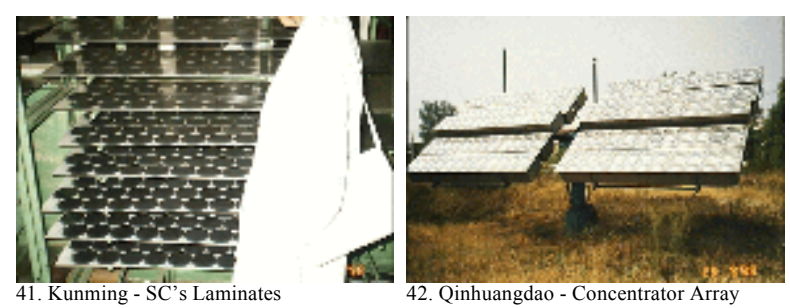

42. Qinhuangdao - Concentrator Array

43. Qinhuangdao - Alpha Solar

Concentrator Cells
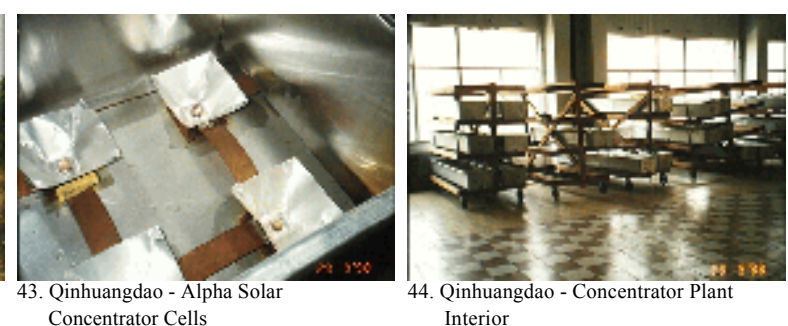

44. Qinhuangdao - Concentrator Plant Interior

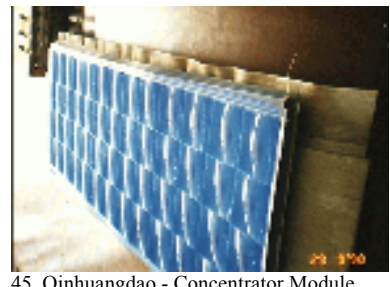

45. Qinhuangdao - Concentrator Module

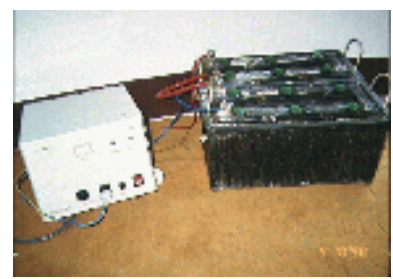

49. Hohhot - Demo House's Storage and Inverter

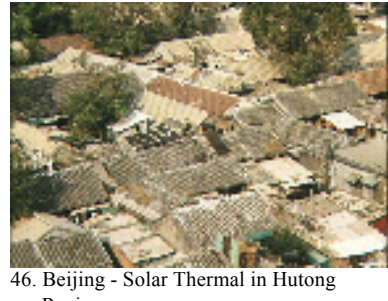

Region

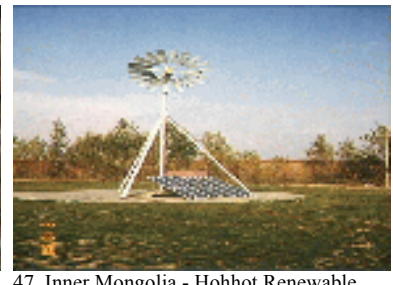

47. Inner Mongolia - Hohhot Renewable Center Demos

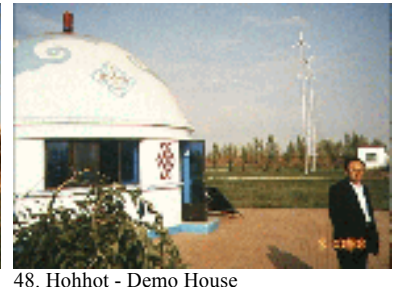

48. Hohhot - Demo House

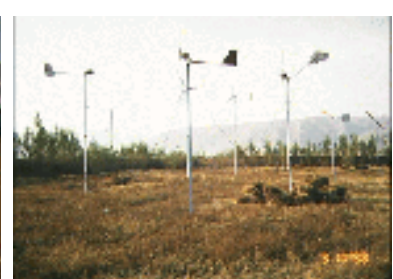

50. Hohhot - Wind Turbines

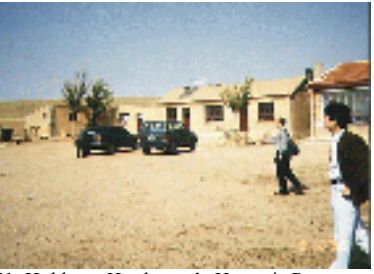

51. Hohhot - Herdsman's Home is Remote

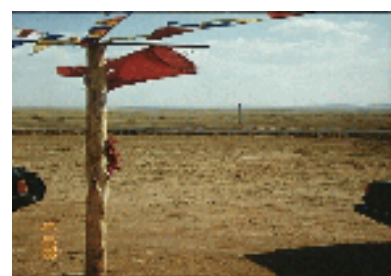

52. Hohhot - Remote Hybrid System

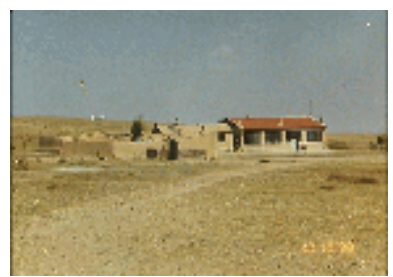

53. Hohhot - Remote Hybrid-Powered Home

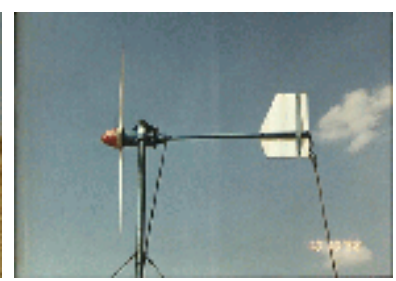

54. Hohhot - Herdsman's Wind Generator

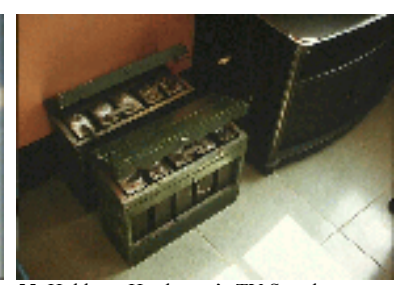

55. Hohhot - Herdsman's TV Supply 


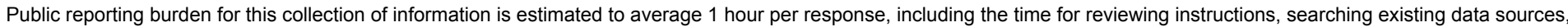

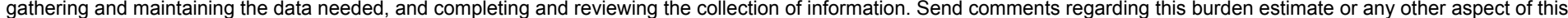

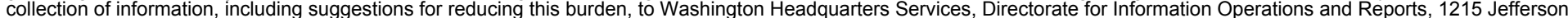

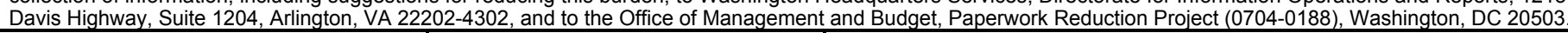
1. AGENCY USE ONLY (Leave blank)
2. REPORT DATE
July 1999
3. REPORT TYPE AND DATES COVERED subcontract; August-October 1998

4. TItLE AND Subtitle China PV Business and Applications Evaluation

5. FUNDING NUMBERS

PV 909002

6. AUTHOR(S)

Chris Sherring \& Associates

7. PERFORMING ORGANIZATION NAME(S) AND ADDRESS(ES)

National Renewable Energy Laboratory

8. PERFORMING ORGANIZATION REPORT NUMBER

1617 Cole Boulevard

Golden, Colorado 80401-3393

NREL/SR-520-26295

9. SPONSORING/MONITORING AGENCY NAME(S) AND ADDRESS(ES)

U.S. Department of Energy

1000 Independence Ave., SW

10. SPONSORING/MONITORING AGENCY REPORT NUMBER

Washington, DC 20585

11. SUPPLEMENTARY NOTES

12a. DISTRIBUTION/AVAILABILITY STATEMENT

National Technical Information Service

U.S. Department of Commerce

5285 Port Royal Road

Springfield, VA 22161 12b. DISTRIBUTION CODE

UC 1503

13. ABSTRACT (Maximum 200 words) This report provides an overview of photovoltaics (PV) business and applications in China. Although more than 70 million people in China are without access to grid electricity, many of the unelectrified regions benefit from considerable renewable resources, including good solar insolation. Current annual PV sales are still modest, however, and are estimated to be between 2.0 and 2.5 megawatts. This and other significant PV data, including information regarding the current status of key aspects of Chinese businesses, markets, and distribution channels, are included in the report. Detailed company profiles of Chinese business organizations and summaries of visits made to these companies (as well as to more remote sites in Inner Mongolia to examine PV usage by the end-use customer) in September-October 1998 are also presented.

14. SUBJECT TERMS

photovoltaics; foreign markets for renewable energy; China's PV markets

15. NUMBER OF PAGES

16. PRICE CODE

19. SECURITY CLASSIFICATION OF ABSTRACT unclassified
20. LIMITATION OF ABSTRACT UL
OF REPORT

unclassified
18. SECURITY CLASSIFICATION OF THIS PAGE unclassified
Standard Form 298 (Rev. 2-89) Prescribed by ANSI Std. Z39-18 